\title{
LUÍS ROGÉRIO DA SILVA
}

\section{Operadores na Constituição Textual}

Dissertação de Mestrado Apresentada ao Programa de Pós-Graduação em Lingüística, Área de Concentração de Semiótica e Lingüística Geral, do Departamento de Lingüística da Faculdade de Filosofia, Letras e Ciências Humanas da Universidade de São Paulo.

Orientadora: Zilda Maria Zapparoli.

\section{SÃO PAULO \\ 2006}


LUÍS ROGÉRIO DA SILVA

Operadores na Constituição Textual

\author{
SÃo PAULO \\ 2006
}




\section{AGRADECIMENTOS}

Agradeço a Zilda Zapparoli, pela orientação constante e meticulosa.

Agradeço a Eliane Gonçalves, minha sempre companheira.

Agradeço a Izilda, Neila e Vanessa, pela colaboração inestimável. 


\section{Sumário}

\section{Sumário}

Índice de Gráficos

Índice de Figuras

Índice de Tabelas

Resumo

Abstract

Introdução

1. Âmbito e Natureza da Pesquisa $\quad 17$

$\begin{array}{ll}1.1 \text { Caracterização da Pesquisa } & 17\end{array}$

$\begin{array}{ll}1.2 \text { Motivação da Pesquisa } & 26\end{array}$

$\begin{array}{ll}1.3 \text { Objetivo da Pesquisa } & 28\end{array}$

$\begin{array}{ll}1.4 \text { O Problema } & 29\end{array}$

2. Pressupostos Teóricos

$\begin{array}{ll}2.1 \mathrm{O} \text { Texto } & 37\end{array}$

2.2 Coesão e Coerência $\quad 55$

2.3 Leitura e Avaliação $\quad 72$

3. Fundamentação da Modelagem Estatístico-Computacional 105

3.1 O Metodo de André Camlong $\quad 105$

3.2 Inferência Estatística $\quad 111$

3.2.1 Comparação de Médias para Duas Populações 113

4. Procedimento Metodológico e Análise Estatística $\quad 116$

4.1 Constituição do Corpus $\quad 116$

$\begin{array}{ll}\text { 4.2 Tratamento do Corpus } & 118\end{array}$

4.3 Organização Digital do Corpus $\quad 123$

4.4 O Banco de Dados $\quad 128$

4.5 Os Relatórios e As Planilhas 132

4.6 O Resultado da Correlação $\quad 133$

5. Análise dos Resultados $\quad 135$

Conclusão $\quad 151$

$\begin{array}{lr}\text { Bibliografia } & 160\end{array}$

$\begin{array}{lr}\text { Anexos } & 168\end{array}$ 


\section{Índice de Gráficos}

Distribuição das Freqüências I 145

Distribuição das Frequiências OS 


\section{Índice de Figuras}

Relacionamento das Tabelas do Banco de Dados "Redações" 


\section{Índice de Tabelas}

Tabela de Observações $\quad 96$

Tabela de Grupo x Amostra 114

Tabela de Redações e Freqüências Relativas 136

Tabela de Redações OS e Freqüências Relativas 137

Tabela de Redações I e Frequiências Relativas $\quad 141$

Tabela de Redações Aleatórias e Freqüências Relativas $\quad 142$

Tabela de Qualidade x Posição 147

Tabela Grupo x Proporção 147 
SILVA, Luís Rogério: Operadores na Constituição Textual. Dissertação de Mestrado. Departamento de Lingüística. Faculdade de Filosofia, Letras e Ciências Humanas da Universidade de São Paulo.

\section{Resumo}

Esta dissertação parte do pressuposto de que os operadores argumentativos e os conectivos, que, aqui, chamamos genericamente de operadores, estão correlacionados com a tessitura textual e pretende verificar se a freqüência relativa da ocorrência deles influi no grau de coesão e coerência que se atribui ao texto no momento da sua leitura.

O substrato de trabalho é constituído por um conjunto de redações produzidas para as atividades propostas em diversas disciplinas que envolvem a prática de redação.

As redações foram avaliadas por três professores de Língua Portuguesa de Ensino Médio e Ensino Superior de acordo com critérios em que o grau de coesão e coerência é o requisito mais relevante para averiguação. 
Procuramos, então, constatar a dependência entre a freqüiência relativa de operadores e a nota fornecida pelos avaliadores.

Os resultados sugerem a existência dessa dependência, mesmo quando os operadores selecionados não se apresentam corretamente empregados segundo as operações lógicas usuais previstas pela sintaxe. 
SILVA, Luís Rogério da: Operators in Textual Constitution. Master Dissertation. Departamento de Lingüística. Faculdade de Filosofia, Letras e Ciências Humanas da Universidade de São Paulo.

\section{Abstract}

This dissertation begins with connective and argumentative operators, called here, generally, as operators, which are related to textual texture and intends to check if the relative frequency of their occurrence influences on the degree of cohesion and coherence that attributes to the text at the moment of its reading.

The substrate of the work is constituted by a group of compositions produced for the proposal activities in several subjects, which involves composition practice.

Three Portuguese Language of High School and College teachers according to the criteria in which the degree of cohesion and coherence is the most important requisite for checking evaluated the compositions.

We look for to verify the dependence between the relative frequency of operators and the grade attributed by the professors. 
The results suggest the existence of this dependence, even when the selected operators don't present themselves correctly used according to the usual and normal operations required by syntax. 


\section{Introdução}




\section{Introdução}

A avaliação do grau de textualidade de uma produção escrita tem dois benefícios imediatos: impedir que se gaste tempo de processamento de textos que, por problemas estruturais, não atingem os objetivos pretendidos e facilitar o desenvolvimento de estratégias de ensino dos recursos lingüísticos necessários para a redação.

De fato, o enfraquecimento da consistência estrutural do texto e a desarticulação das suas partes impedem que, sobre ele, os processamentos computacionais de sumarização e de busca obtenham êxito.

Isso se dá, porque a sumarização tem como premissa a condensação, que preserva a coerência, e implica, necessariamente, omissões de tópicos e detalhes que, tendo em vista o todo do texto-base, não interferem na apreensão da mensagem proposta ou que podem ser recuperados pela ação da leitura. Assim, quanto menos articuladas são as partes do texto-base, mais complexo se torna condensá-lo.

Também é verdade que a busca de informações se depara, dia após dia, com uma quantidade crescente de fontes e, por mais eficiente que seja a seleção, um número considerável de textos de baixa 
informatividade ${ }^{1}$ estará reunido aos demais, que são o foco de interesse, e terá de ser descartado pelo esforço da leitura.

Os problemas computacionais podem ter a solução otimizada por um pré-processamento que seja capaz de descartar, com um nível de significância estabelecido, os escritos que não constituam textos, recusando-os simplesmente, ou deixando-os para uma intervenção que repare os problemas de tessitura textual.

A descoberta de meios quantitativos para a avaliação do potencial textual de um escrito é importante para que se criem algoritmos capazes de auxiliar-nos nessa tarefa.

À vantagem já apontada, acrescentamos a facilitação, pelo instrumento computacional, da atividade de correção de redação do ponto de vista dos indícios de coesão e coerência encontrados no texto.

Nosso objetivo é verificar se a coesão e a coerência de um texto podem ser correlacionadas a algum padrão de distribuição de elementos ligantes das orações e dos períodos que o constituem. Para tanto, recolhemos vários conjuntos de dissertações com suas respectivas propostas de trabalho, tiramos desses grupos aquelas que não atendiam às especificações ou tergiversaram o tema e, nas restantes, comparamos, em

\footnotetext{
${ }^{1}$ Informatividade é a taxa de transferência de informações substanciais de uma mensagem por meio de um texto. (RINO, 1996, p. 34)
} 
busca de padrões, a distribuição de frequiências relativas dos elementos ligantes às notas atribuídas pelos professores, tendo em vista a avaliação da coesão e coerência dos textos.

Por fim, procuramos fazer uma análise dos resultados estatísticos frente às relações intratextuais subjacentes em cada redação avaliada, visando a estabelecer os limites de validade entre a constatação estatística abstrata e o seu substrato físico concreto.

Esta dissertação está dividida em cinco partes: a primeira expõe o âmbito e a natureza da pesquisa; a segunda apresenta o suporte teórico necessário para a abordagem dos fatos lingüísticos tratados estatisticamente; a terceira esclarece o modelo estatístico-computacional e os modelos estatísticos aplicados para a interpretação dos dados oriundos da distribuição dos elementos lexicais de interesse, bem como para a avaliação de hipóteses; a quarta apresenta o corpus textual e discute os procedimentos realizados para a obtenção dos dados empregados nas análises estatísticas; a quinta visa a esclarecer as relações entre as constatações estatísticas e os fatos lingüísticos relevantes. 


\section{Âmbito e Natureza da Pesquisa}




\section{1 Âmbito e Natureza da Pesquisa}

\subsection{Caracterização da Pesquisa}

Para os estudos de línguas naturais em que existe a intervenção de instrumentos matemático-computacionais para a obtenção de conclusões, duas etapas somam-se, irreversivelmente, à análise lingüística desenvolvida pelo pesquisador, a saber:

a) a modelagem matemática aplicada;

b) o projeto de algoritmo produzido.

Entenda-se aqui por modelagem matemática o uso do formalismo matemático para a transcrição do conjunto objeto de pesquisa formado pelo fenômeno - o referente estabelecido pelo pesquisador (ALTMAN, 1998, p. 49) - e pelo seu tratamento a partir de um determinado paradigma lingüístico. É, portanto, por meio desse formalismo, que se observam, de maneira qualitativa e quantitativa, os resultados concernentes à abordagem escolhida para o fenômeno em estudo.

Ainda que, muitas vezes, não explicitados no corpo dos textos de publicação, esses dois passos não apenas diferenciam duas pesquisas de 
mesmo paradigma lingüístico, mas também fornecem limites diferentes

dentro dos quais se possam considerar válidas as conclusões obtidas. Assim, as hipóteses iniciais adotadas no momento de se gerar a modelagem matemática devem ser consideradas para restringir a amplitude das conclusões; dessa forma, o seu desconhecimento enfraquece o valor das afirmações finais ${ }^{2}$.

O projeto de algoritmos, da mesma maneira que a modelagem matemática, está intrinsecamente vinculado à pesquisa desenvolvida, pois não resulta como pura transcrição da modelagem matemática. $O$ computador apresenta restrições técnicas que a modelagem matemática, por vezes, ignora. Assim, uma ação de busca simples pode ter complexidade muito distinta, dependendo do algoritmo usado, conforme ilustra SCHILDT (1989, p. 3):

Em meados de 1970, computadores com grandes memórias eram comuns, e a velocidade de processamento aumentou drasticamente. No entanto, mesmo com esses melhoramentos, muitos dos velhos métodos utilizados em IA continuavam a falhar, porque eram de uma ineficiência inerente. Por exemplo, considere alguma coisa tão simples como ordenar um vetor de números. Se você utilizar uma

2 "A ciência, na sua forma ideal, consiste numa série de proposições arranjadas hierarquicamente, de tal modo que o grau inferior dessa hierarquia se refere a fatos particulares, enquanto que o topo se refere a algumas leis gerais que governam tudo no universo.” (Russel, 1977, p. 50). Considerando que o conhecimento científico é uma dupla conexão lógica (em um sentido é indutivo, em outro é dedutivo), o conjunto verdade de proposições de chegada depende das restrições do patamar de partida. 
ordenação pelo método da bolha, o tempo de ordenação será proporcional a N2, onde $\mathbf{N}$ é o número de elementos. Assim, se para ordenar um vetor de dez elementos leva-se um segundo, para ordenar um vetor de cem elementos precisaremos de cem segundos, $\mathrm{e}$ assim por diante. Portanto existem vetores que levarão mais tempo para ser ordenados que a idade média de um homem! Não importa quão mais rápidos tornam-se os computadores; um algoritmo de ordenação onde o tempo de ordenação é proporcional a N2 torna-se rapidamente muito lento. $O$ melhor método é alterar o algoritmo de ordenação de modo a torná-lo eficiente. Por exemplo, o tempo de ordenação do algoritmo Quicksort é proporcional a N1.2 ${ }^{3}$ uma melhora significativa.

Como dissemos na Introdução, o nosso objetivo de estudo é o relacionamento entre a presença dos operadores argumentativos e dos conectivos, mais precisamente, entre a distribuição de freqüência relativa em que são encontrados no texto e o grau de coesão e coerência, segundo a avaliação feita por um leitor privilegiado - o professor.

Se existir a relação citada, torna-se possível construir um algoritmo que avalie, estatisticamente, a coesão e a coerência sem ter de recorrer ao conjunto lexical empregado nem destrinchar a sintaxe em busca da análise semântica.

\footnotetext{
${ }^{3} \mathrm{O}$ quicksort é um algoritmo cujo tempo de execução do caso médio se aproxima de $\mathrm{O}(n \lg n)$. Enquanto que um algoritmo de inserção levaria o tempo, para a ordenação de100 elementos, de até 10000 comparações, o quicksort leva em média o tempo proporcional a 200 comparações. Trazendo esse problema de complexidade para o âmbito do tratamento lingüístico-computacional, seria o mesmo que um algoritmo necessitar de todo o conjunto léxico disponível no corpus de estudo, para permitir uma conclusão, ao passo que, para outro, bastasse constatar a presença de uma parcela do conjunto para atingir igual objetivo.
} 
Se, para efeito desta dissertação, os operadores constituem uma classe que abarca tanto os operadores argumentativos quanto os conectivos, convém definir essas duas subclasses.

Os operadores argumentativos são os conectivos lógicos que se aplicam a um enunciado, conferindo-lhe um potencial argumentativo específico, enquanto que os conectivos podem, segundo MAINGUENEAU:

ligar não apenas proposições, mas também enunciações a proposições, e mesmo encadear com elementos da situação extralingüística ou com reações não ditas que o locutor atribui a si mesmo ou ao destinatário. Dito de outra forma, os elementos conectados podem perfeitamente ser de naturezas distintas. (MAINGUENEAU, 1997, p.162)

A modelagem matemática adotada ficou dividida em três etapas:

a) a verificação se o uso da correlação baseada no Método de Camlong auxilia na seleção do conjunto de redações a serem submetidas ao procedimento desta pesquisa;

b) a seleção e etiquetagem do que se entende por operadores no corpus;

c) a aplicação dos Testes de Hipótese. 
O algoritmo adotado para a primeira parte está implementado

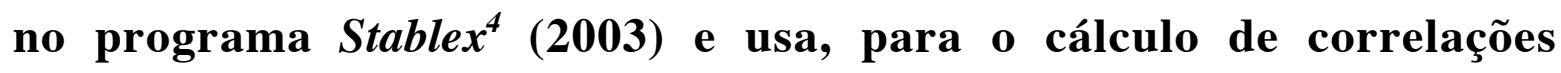
múltiplas, macros suportadas em planilhas do Excel $^{5}$.

Para a segunda parte, o uso de algoritmo para etiquetagem dos operadores não se mostrou confiável para a implementação, pois, por ele, não se consegue ter a capacidade de distinguir, com exatidão, a situação de quando uma lexia faz o papel de operador daquela outra situação em que a mesma lexia não cumpre essa função.

A atuação do etiquetador pode ser demonstrada a partir do trecho abaixo:

João e Maria foram para a floresta. João espantava os pássaros e Maria deixava cair migalhas de pão... João pediu a Maria que fugisse e Maria saiu da sala correndo...

Para o conectivo $e$, por exemplo, a transcrição feita, por etiquetador, poderá ser:

\footnotetext{
${ }^{4}$ O programa Stablex foi concebido a partir dos trabalhos em lingüística e estatística de André Camlong e Thierry Beltrand.
} 
João op1 Maria foram para a floresta. João espantava os pássaros

op1 Maria deixava cair migalhas de pão... João pediu a Maria que

fugisse op1 Maria saiu da sala correndo...

Nota-se, porém, que nem todos os operadores assinalados serão, de fato, assinalados como tais pelos critérios que adotamos. Passa a ser fundamental, portanto, um trabalho de revisão manual, pois qualquer identificação inadequada poderia alterar a contagem de operadores e, por conseguinte, falsear o teste de hipóteses ${ }^{6}$.

Consideramos, pois, desnecessário descrever, minuciosamente, o algoritmo de etiquetagem, que passou a ter apenas um papel auxiliar de seleção, em benefício de apresentar a forma como foi feito o critério de seleção de operadores para os casos mais discutíveis.

\footnotetext{
${ }^{6} \mathrm{O}$ exemplo "João e Maria foram para a floresta. João espantava os pássaros e Maria deixava cair migalhas de pão..." apresenta os atos de "espantar" e "deixar cair" como independentes e simplesmente aditivos. Já em "João pediu a Maria que fugisse e Maria saiu da sala correndo...". Está claro que a saída de Maria decorre do pedido de João. Apesar de o conector ser o mesmo, a implicação semântica não é igual nos dois casos: no primeiro, as ações podem ser simultâneas e independentes; no segundo, faz-se supor que o pedido antecedeu à fuga e foi a sua causa. Se etiquetarmos, nesse trecho, qualquer 'e' isolado como operador, substituindo 'e' por 'op1', indiscriminadamente, teremos "João op1 Maria foram para a floresta. João espantava os pássaros op1 Maria deixava cair migalhas de pão... João pediu a Maria que fugisse op1 Maria saiu da sala correndo...". Teremos, então, três operadores a serem contabilizados. Entretanto, se não fosse de interesse que considerássemos a adição de sujeitos para a constituição de sujeito composto, teríamos dois operadores; ainda mais, se, também, não estivesse no escopo deste trabalho os conectivos de adição, restaria apenas um operador. Como tais distinções um programa etiquetador não é capaz de fazer, os valores absolutos contabilizados, através dele, não são confiáveis para representar a seleção desejada de operadores.
} 
O objeto de análise desta pesquisa foi obtido das atividades de escritura de textos realizadas em sala de aula por orientação de professores.

Um grupo de redações escritas em papel foi coletado, tendo em vista que se tratava de uma avaliação de desempenho. Em seguida, cada redação foi digitada e teve atribuída uma referência digital em um banco de dados ${ }^{7}$.

Essas redações em papel passaram a ter, por correspondência, uma redação digital, um registro num banco de dados e, para esse registro, os dados relativos aos campos nota, proposta de atividade, data, professor e um código de identificação do aluno-autor.

A partir dessa etapa, o conjunto de redações coletado passou a ter a mesma estrutura de informação que qualquer redação obtida por educação virtual ${ }^{8}$, de tal maneira que a modelagem aplicada pela presente pesquisa atende, de forma equivalente, aos anseios da educação a distância, e os seus resultados também podem ser aplicados nessa forma de ensino.

Vale lembrar que o interesse desta pesquisa está na verificação da capacidade de reconhecimento de textos coesos e coerentes por meio de

\footnotetext{
${ }^{7} \mathrm{O}$ banco de dados consta em anexo e a sua descrição encontra-se na quarta parte.

${ }^{8}$ Educação virtual é a educação realizada à distância mediada por computador.
} 
uma aplicação estatístico-computacional e, para tanto, a definição das propriedades quantitativas que possam estar relacionadas ao grau de tessitura é essencial para a consistência da modelagem adotada.

Trata-se, pois, de uma pesquisa qualitativa e também quantitativa, de um lado aborda avaliações calcadas naquilo que o processo de leitura é capaz de fazer o leitor experimentar, tendo em conta o texto que lê, de outro contabiliza o número de operadores para observar as freqüências relativas e, junto das medidas de dispersão, fazer a correlação, quando possível, entre os fatos qualitativos e os quantitativos, para vislumbrar características lingüísticas estruturais.

Congrega, pois, subsídios de várias perspectivas teóricas que se dedicam aos estudos voltados para questões relacionadas à leitura e à escrita, sobretudo para a observação da relação texto-autor-leitor-suporte. Deve ter, também, o aporte conceitual da pedagogia, no que tange ao alcance limítrofe atingido pelos procedimentos de avaliação quantitativa9 e classificatória. Isso tudo para que se compreendam os fatos qualitativos.

Já para os fatos quantitativos, faz-se necessária a aplicação de alguns instrumentos caros à Lingüística de corpus, como a estatística e a

\footnotetext{
${ }^{9}$ As avaliações de redações que resultam em valores numéricos como expressão da qualidade aquilatada dos textos, não raras vezes, apresentam discrepâncias se comparados os valores atribuídos por examinadores distintos. Assim, devem ser considerados métodos para dar condições de se obter resultados de avaliações que melhor representem a qualidade do objeto em questão.
} 
computação. Essa combinação propicia o levantamento de padrões da linguagem, essencial para se construir, indutivamente, um paradigma que responda bem ao que se constata dos dados.

Entretanto, distintamente do método próprio da Lingüística de corpus, de construir o conhecimento de forma, irremediavelmente, indutiva, o que se pretende aqui é encontrar, pelos padrões, as estruturas, confrontá-las com os modelos teóricos que abarcam os fatos qualitativos e mostrar como os padrões se impõem e são fundamentais para o reconhecimento da realização do sistema lingüístico. Ainda mais, visa a concluir que as possibilidades de enunciação podem não estar completamente compreendidas num sistema composto de léxico e regras, mas estão conformadas em estruturas detectáveis em análise estatística ${ }^{10}$.

Destarte, são os operadores argumentativos e, também, os conectivos, doravante chamados simplesmente de operadores, os elementos escolhidos para fornecer os dados quantitativos a serem usados nas análises estatísticas. Essas análises devem culminar na resposta se, para a modelagem adotada, existe relação de dependência entre a frequiência relativa dos operadores e o grau de tessitura observado.

${ }^{10}$ Segundo Sinclair (1991, p.110), o falante nativo dispõe de frases semi-construídas que se constituem em escolhas. 


\subsection{Motivação da Pesquisa}

Todos os processos de prospecção de informação com base em textos escritos têm como ponto de partida que o objeto de trabalho é, de antemão, um texto e, portanto, coerente e coeso.

Assim, procedimentos de busca semântica, sumarização e outras formas de manipulação computacional de textos escritos partem do pressuposto de que existe, no seu objeto de trabalho, uma composição bem-estruturada.

Por outro lado, o usuário espera de muitos desses aplicativos um resultado também condizente com a definição de texto, ou seja, em se tratando, por exemplo, de um sumarizador, que o resumo obtido apresente coesão, coerência e um alto grau de informatividade.

Se o volume de textos escritos justifica a adoção de procedimentos computacionais para a manipulação textual, é natural concluir que a averiguação prévia de que o objeto de trabalho é texto e não uma coleção de palavras, ou de orações, ou ainda de parágrafos é tão importante quanto o aplicativo computacional responsável pela tarefa sobre o texto. 
De forma análoga, pode-se considerar imprescindível saber se não ocorrem frases desconexas no interior de uma grande coleção de textos gerados computacionalmente, quando de uma operação em que o produto esperado de uma intervenção computacional é um texto escrito.

Para esses casos apontados, é relevante a busca de propriedades estatísticas capazes de determinar, por meio de um nível de significância pré-estabelecido, se uma coleção de palavras é um texto ou não.

Também é fato que, com a popularização da educação virtual e dos processos de seleção de candidatos por intermédio de provas eletrônicas, se procurem instrumentos para auxiliar a tarefa de avaliação dos textos produzidos, seja pelos alunos, seja pelos candidatos às vagas oferecidas.

Conclui-se, portanto, que estratégias de avaliação do grau de tessitura a partir da coesão e da coerência encontradas são de interesse para agilizar atividades que envolvem um grande volume de textos. 


\subsection{Objetivo da Pesquisa}

Retornando e precisando, o objetivo principal desta dissertação é averiguar se a modelagem matemática aqui desenvolvida, baseada na coleta seletiva de ligantes - operadores -, é capaz de fornecer resultados que mostrem a existência de dependência entre a freqüência relativa desses elementos num texto escrito e a avaliação do grau de coesão e coerência nele observado por um profissional no papel de leitor. Isso significa verificar a existência de padrões no emprego de operadores, de tal forma que, provavelmente, para determinadas freqüências relativas de ocorrência desses elementos, ocorra facilitação no processo de leitura.

Matematicamente, a afirmação acima pode ser expressa, de maneira equivalente, como se segue:

Existe uma maneira de se obter uma função de Notas a partir de uma função da freqüência relativa de $n$ operadores escolhidos. 


\subsection{O Problema}

O problema que propomos resolver pode ser expresso como a verificação, por meio da análise estatística, da existência de dependência entre a freqüência relativa de operadores encontrada nas redações e as respectivas avaliações realizadas sob o enfoque da tessitura observada.

São hipóteses consideradas para a abordagem desse problema:

a) os enunciados argumentativos são marcados;

b) as marcas dos enunciados argumentativos são referências a operadores e, mesmo que não respeitem regras lógicas, podem sugerir a existência delas;

c) as marcas dos enunciados argumentativos fazem papel de ligantes inter e intratextuais;

d) os operadores sugerem ao leitor a existência de coesão textual e servem de marcas observáveis durante a leitura;

e) existe uma faixa padrão de distribuição de operadores no enunciado, fora da qual o interlocutor considerará prejudicada a sua tessitura; 
f) a coesão e a coerência são características textuais que, no texto escrito, constituem-se durante a dinâmica do processo de leitura e, portanto, também dependem da estratégia adotada pelo leitor;

g) as marcas servem como pistas do gênero do texto e visam, também, a facilitar ao leitor encontrar a estratégia mais adequada para a sua leitura.

O problema, por conseguinte, deixa implícito que também se busca a verificação da abrangência das hipóteses acima consideradas, que fundamentam a modelagem matemática aplicada. 
Pressupostos Teóricos 


\section{Pressupostos Teóricos}

Esta pesquisa estabelece elo entre atributos estruturais da constituição textual e aspectos valorativos auferidos pela leitura por conta de critérios pré-estabelecidos.

Trata-se, pois, de uma pesquisa que busca encontrar relação entre variáveis quantitativas, passíveis de serem averiguadas de forma objetiva com retaguarda de modelos teóricos estruturais, e variáveis qualitativas, para as quais os modelos teóricos envolvidos avaliam o texto por instrumentos subjetivos, dependentes, sobretudo, da construção da interpretação textual.

Colocamos, desta feita, lado a lado, os operadores, que constituem uma variável naturalmente contável, cuja maior dificuldade seria definir os seus atributos relevantes para poder identificá-los, e os conceitos representativos da qualidade textual averiguada pela leitura. Decorre ser inevitável que falemos de linhas teóricas distintas que abordam a textualidade, simplesmente pela razão de estarem dando relevância às diferentes variáveis de nosso interesse, cujo vínculo comum é o elo textual. 
A problemática proposta também é de natureza multidisciplinar, pois reúne abordagens lingüísticas estruturais e dialógicas, os conceitos pedagógicos envolvidos nos processos de avaliação de redações, a análise estatística e o aparato computacional.

Assim, se Koch, Ducrot e Maingueneau auxiliam na tarefa de definir o que para nós será tido como operador, cabe a Van Dijk e Kintch, Smith, Ferrero e Teberovsky inspirar teoricamente a confecção dos nossos critérios de avaliação textual que, por cuidado, procuramos comparar com os de Val e Therezo.

Em termos de fundamentação teórica, uma atenção especial foi dada à leitura e avaliação de textos para evitar que os critérios adotados nesta pesquisa provocassem uma quantidade significativa de casos de notas discrepantes para um mesmo texto.

Vale notar que, ao contrário do que se espera de uma variável contável, em que uma definição objetiva, praticamente, elimina as possíveis divergências, no momento da coleta e classificação dos dados, o lidar com uma variável subjetiva exige que se recorra a uma solução consensual para todo dado coletado.

A clareza dos preceitos envolvidos na decisão de uma nota atribuída é, portanto, fundamental. 
A fundamentação teórica é, para esta pesquisa, uma maneira de explicarmos a razão de persistirmos na busca de um padrão estrutural do texto que esteja relacionado a uma propriedade semântica que permita, assim, atribuir dependência quantitativa entre parâmetros objetivos e subjetivos.

A forma como buscamos encontrar essa relação não permite que encontremos suporte para as nossas reflexões numa única abordagem lingüística sobre o que é o texto.

De fato, é conveniente que, antes de discutirmos as diversas formas com que o texto é abordado, expressemos algumas características suas que consideramos basilares para esta pesquisa, principalmente, no que tange à intersecção que fazemos, através do texto, entre o produto antes e após a leitura.

O texto, portanto, será, para nós, uma superposição de estruturas, a saber:

a) Uma estrutura basal, que consiste na constituição da frase. Portanto, pode ser avaliada pelos estudos que se dedicam ao léxico e a sintaxe; 
b) Uma estrutura intermediária, que consiste na constituição do tópico ${ }^{11}$. Portanto, pode ser avaliada pelos estudos que se dedicam à semântica e à pragmática.

c) Uma estrutura superior, que consiste na reunião de vários tópicos. Esta, que representa a capacidade de satisfazer as expectativas mútuas entre enunciador e enunciatário, encontra-se sob o enfoque das linhas da lingüística que analisam o discurso. É através dessa estrutura que avaliamos se um texto é apropriado ou não à prática social em que está inserido.

Vemos que, desse ponto de vista, a nossa pesquisa pretende encontrar uma relação quantitativa entre o que se observa no nível basal e aquilo que se avalia no nível superior.

Para efeito dos critérios de avaliação, o texto se expressa através da estrutura superior, das qualidades dos tópicos e da relação entre eles.

A sua qualidade depende da forma com que cada tópico se insere no contexto definido pelos demais e de como a unidade que constitui está adequada ao contexto da enunciação.

\footnotetext{
${ }^{11}$ Não se trata do parágrafo, mas de um conjunto de elementos frásicos subseqüentes que se centram num
} tema. 
Já, no âmbito do quantitativo, daquilo que queremos tornar contabilizável, o texto se faz realizado através do léxico e da sintaxe. 


\subsection{O Texto}

O estabelecimento da coesão e da coerência como pré-requisitos para a constituição do texto exige que se explicite a noção de texto a que estamos recorrendo.

Em primeiro lugar, convém esclarecer que a nossa atenção pousa sobre a linguagem verbal e que, conseqüentemente, o texto a que fazemos referência está sob essa restrição.

O texto, conforme antecipamos, é, para nossa pesquisa, unidade do discurso decorrente da realização de um percurso informacional por parte de interlocutores. Conseqüentemente, não é pela extensão do enunciado que se lhe atribui a qualidade de texto, mas sim pela sua unidade.

Aqui a unidade significa que nenhum conceito formulado ou referido estará dissociado dos demais existentes no corpo do texto. Assim, o texto não é apenas o conjunto que contém todos os conceitos expressos, explicitamente ou não, no enunciado, mas também o conjunto de relações que entrelaçam todos esses conceitos.

Se houver respeito a esse critério de unidade acima referido, uma frase pode constituir um texto, enquanto que um conjunto de várias frases 
desconexas, mesmo que obedecendo a uma restrição temática, não atinge o mesmo status.

Então, ao nos referirmos à estrutura enunciativa do texto como a um percurso realizado, compreendemos que, neste, está estabelecido um processo comunicativo, cujo produto tem, como característica fundamental, a unidade. Ainda que a leitura de um texto remeta a digressões e que outros mecanismos de dispersão possam operar durante a sua realização, a intenção da composição é dar a um conjunto de enunciados a consistência da unidade semântica.

Enquanto o discurso está no âmbito social e guarda, por sua natureza, a capacidade imanente de revelar o caráter ideológico da linguagem, o texto, em sua unidade, representa a expressão individual desse arcabouço ideológico, o que pressupõe a ação do sujeito sobre a linguagem.

Como o texto pressupõe a existência de um processo comunicativo, sugere, mesmo em sua modalidade escrita, a constituição da relação entre o sujeito e o outro, a composição das faces que assumem e, portanto, a composição textual é realizada sob a égide do dialogismo.

A unidade a que nos referimos, pois, não é, necessariamente, fruto de construção fácil oriundo de um processo ameno de diálogo, mas 
resultado, geralmente, de uma intervenção contínua de vozes, que, por vezes, são de outros textos, estão implícitas, contraditas no texto em composição ou que nele ganham anuência.

Assim, o papel de sujeito pode ser exercido por uma variedade de enunciadores sob a forma de um articulado de vozes apresentadas, convenientemente, para dar enlace à estrutura semântica do texto em seu nível profundo.

Afirma BARROS (1988, p. 103) que "a enunciação projeta-se numa pluralidade de vozes que realizam diferentes atos ilocucionais, sendo o discurso, essencialmente, polifônico".

A realização do processo de comunicação representa, portanto, a maneira como decorre a interação. Esta, por meio do texto, pode se dar pela combinação dos atos locutório (produzido segundo as regras de um sistema gramatical), ilocutório (visa a influenciar o comportamento do receptor) e perlocutório (responsável pelo efeito produzido no alocutário).

O texto, como objeto de estudo, tem sido observado sob o prisma de diversos modelos teóricos que procuram descrever a sua natureza desde a produção até a recepção. Para efeito de entendimento do texto em sua unidade, cabe buscar os âmbitos, da produção à recepção, capazes de 
fornecer tanto os parâmetros qualitativo e quantitativo para a avaliação da sua urdidura, quanto a descrição dos processos lingüísticos envolvidos.

Considerando-se que a referida unidade represente uma determinada configuração semântica, convém que se observe como se estabelece o significado.

Consideramos que a leitura tem, diante de um texto, a capacidade de dar concatenação às partes do enunciado e aos enunciados entre si, conferindo pelo menos uma configuração semântica consistente.

É do processo de leitura que se supõe a decodificação da estrutura realizada da língua, na qual se fecha o elo comunicativo estabelecido entre o enunciador e o enunciatário. o responsável pela constituição de pelo menos uma unidade dotada de significado para o leitor.

Assim, a depreensão do significado oriundo da seqüência das palavras, articuladas conforme as regras sintáticas, não implica a compreensão total do significado do enunciado.

O contexto tem, portanto, papel decisivo na compreensão de um enunciado e, em se tratando de textos escritos, o repertório do leitor é muito importante para que se decifrem as pistas deixadas pelo autor para preservar as informações do contexto da enunciação. 
Concorrem, então, para a leitura de um texto os resíduos observáveis do contexto da enunciação. Esses podem estar apenas incrustrados materialmente no enunciado ou, estando o enunciatário presente quando do processo de enunciação, podem ser testemunhados em sua natureza segmental e supra-segmental.

É indiscutível que é condição necessária, para que se complete o processo de significação de um texto, a total depreensão de sua temática.

A intelecção de um tema ${ }^{12}$ não se faz garantida apenas pela seqüência de um conjunto de enunciados gramaticalmente corretos. Tal fato demonstra que, para o estudo da constituição do significado de um texto, é imprescindível fazer uma análise estrutural superior àquela que se atém ao resultado da associação de lexias, faz-se necessário um estudo sobre como se formam e como se articulam blocos semânticos para que se consiga constituir um texto.

Se nos fixarmos na leitura de um texto, na depreensão do seu tema e na compreensão dos múltiplos significados que concorrem para a sua constituição, podemos nos referir à tipologia de texto às avessas, não baseada no que o autor teve por intenção fazer do texto - uma descrição, um relato, uma argumentação -, mas orientada para o que o leitor

\footnotetext{
${ }^{12} \mathrm{O}$ tema faz o contorno semântico de um conjunto concatenado de enunciados, permitindo a compreensão do seu conteúdo.
} 
entende do texto. Então, surgem as perguntas: Percebe o leitor o que o enunciado ali contido descreve? O que vislumbra o leitor? Nota que narra? Percebe como se relacionam os fatos, quanto a sua temporalidade? Segue a argumentação? Parece verdade?

Em relação ao tema do texto, tema entendido aqui como núcleo informativo fundamental ou elemento em torno do qual se estrutura a mensagem, sua identificação permitirá ao receptor considerar “entendido" o texto; daí poderá partir para a elaboração de resumos do texto, ou para exercícios de recriação sob diversas formas (paráfrases, comentários, resenhas, recensões etc.).

O processo seguido pelo receptor é, de certo modo, oposto ao utilizado pelo emissor. Se este procede desenvolvendo o tema, o receptor deverá, reduzindo as informações que lhe são transmitidas, limitar-se ao fundamental, até chegar a esse núcleo informativo. (GUIMARÃES, 2001, p. 17)

A maneira, portanto, como está organizado o texto, o gênero em que se apresenta e a clareza com que o enunciatário é capaz de identificálo, revelam-se úteis para desvelar o tema. Como exemplo, atrevemo-nos a dizer que não basta ao enunciador a intenção de descrever, é necessário que o enunciatário reconheça que se trata de uma descrição, para que possa interagir e desempenhar a leitura da melhor forma que lhe for possível. 
Assim, os gêneros do discurso correspondem a um acordo implícito, estabelecido, durante a enunciação, entre enunciador e enunciatário, o qual se revela pela conjunção entre a estrutura típica do gênero $^{13}$, o que diz e o como diz

O como diz relaciona-se diretamente à maneira como transcorre o processo da enunciação. $O$ sujeito, as vozes dos enunciadores assumidos, o enunciatário, o contexto em que se dá a enunciação referendam ou não a estrutura em que se realiza o enunciado, dando a este último ou o valor verdade, ou sugerindo ironia ou, até, inadequação.

A transposição da análise limitada à dimensão da frase para a do texto, conforme já havíamos frisado anteriormente, implica, portanto, uma mudança no objeto de estudo da linguagem.

A visão européia da análise do discurso defende a idéia de que o estudo da significação é fundamental e supõe a intervenção de conceitos que fazem parte da reflexão sobre as formações sociais.

Dessa maneira, o discurso não deriva de um sistema abstrato nem decorre da instrução aplicada a um código; é, pois, ideológico e não apenas informativo. Para essa corrente, os locutores estão envolvidos no 
processo histórico, já que se introduzem no espaço da discussão pela noção de sujeito, de ideologia e de situação histórico-social.

O discurso é definido como efeito de sentido entre locutores e, além da intenção do locutor, o contexto histórico-social e o como se processa a realização do discurso concorrem para o significado do texto.

A análise do discurso da linha européia mostra, assim, o funcionamento dos textos segundo a sua articulação com as formações ideológicas. É possível afirmar, segundo BRAIT, que:

A idéia mesma de análise do discurso, de enfoque enunciativo, tem já em dois de seus principais discursos fundadores a marca da heterogeneidade: de um lado a questão da presença da subjetividade na linguagem e da possibilidade de seu estudo através das formas lingüísticas, aspecto que remete necessariamente a Benveniste; de outro, a dimensão ideológica ou de “determinaçåo histórica dos processos semânticos" que, mais recentemente sistematizada e ampliada por Pêcheux, tem em Bakhtin a fonte primeira a deslocar o conceito de linguagem dos pólos do que ele denominou "subjetivismo idealista" e objetivismo abstrato". (BRAIT, 1996, p. 100)

Algumas questões decorrentes desse enfoque, mostram-se relevantes para a nossa pesquisa, a saber: Como a escrita vem escandir tal processo, aí produzindo efeito de interpretação? Como o sujeito-leitor emerge nessa escansão? 
De fato, se uma das variáveis a serem descritas, na nossa pesquisa, é representada pelas avaliações sobre o grau de coesão e coerência de cada redação, a partir da leitura realizada pelos professores, torna-se importante incidir a luz sobre o processo de interpretação. Somente assim, podemos observar se as características do texto que supomos importantes para a sua integridade influenciam tanto o processo de leitura quanto a sua conseqüente interpretação.

Ademais cumpre explicar, sob a ótica do processo de leitura, o modo como se constrói o mecanismo da significação do texto para o leitor, pois explicitá-lo fornece substrato lingüístico às inferências estatísticas propostas. Também nos cabe mostrar que, nesse processo, os operadores são os elementos constitutivos do texto que servem de pistas ao leitor para que consiga apreender a organização textual.

Como a nossa proposta é entrelaçar informações da capacidade de depreensão de significado do texto aos dados de freqüência relativa de ocorrências de operadores lexicais, faz-se útil, também, a aplicação de modelos de estudo que proponham o texto como uma composição de elementos e regras dos quais emerge a significação. Assim, recorremos à apropriação de alguns conceitos caros à linha americana. 
Para a linha americana, a passagem da análise da frase para a do texto é uma extensão da análise distribucional. Baseia-se no conceito recursivo de que existe sempre um discurso curto que pode ser considerado uma frase e, conseqüentemente, um discurso é uma frase complexa.

A vantagem dessa forma de trabalhar o problema está na aplicação de um único método para resolvê-lo. Na linha americana, não se fala do significado do texto, mas apenas se determina o como são organizados os elementos que o constituem. Quando entra em consideração o significado, eles propõem adicionar outro componente na gramática, um componente comunicativo.

Essa maneira de conceber a geração textual estimula a aplicação de métodos estatísticos para a descoberta de padrões de uso de elementos constitutivos das línguas e para a elucidação de regras que agem sobre eles.

Poderíamos pensar que, se operadores servem para articular estruturas menores, transformando-as em estruturas mais complexas, porém de igual natureza das primeiras, então existe algum padrão subentendido para o seu uso e, portanto, para a sua ocorrência. 
Esse pressuposto, entretanto, que é o da construção a partir de recorrências de estruturas básicas, não pode explicar o porquê de algumas construções serem mais comuns do que outras e, portanto, o porquê de alguns enunciados serem muito mais freqüentes do que outros, apesar de igualmente aceitos pelo sistema.

$O$ fato de que poucos são os enunciados muito freqüentes e de muitos outros serem incomuns, sugere que exista a intervenção de fatores de contexto.

Como as possibilidades de criação baseadas nesse sistema são incalculáveis, supomos, então, que a realização de um enunciado respeite, também, um critério voltado para o atendimento da necessidade de facilitar a sua depreensão. Isso subentende que construções mais usuais são mais fáceis e rapidamente compreendidas dentro de um determinado contexto de enunciação.

Assim, um ciclo virtuoso se formaria para manter alta a freqüência de ocorrências de alguns enunciados frente a outros que poderiam ser empregados em situações análogas: de um lado, as estruturas mais usadas tendem a se fixar nos modelos aplicados para a leitura pelos enunciatários, facilitando-a; de outro, por serem essas 
estruturas, então, mais eficientemente compreendidas, passam a ser mais enunciadas por economia lingüística.

Dessa forma, o reconhecimento da estrutura do enunciado faria parte de uma estratégia usada para a sua leitura. $O$ processo de leitura seria facilitado pela inserção de marcas deixadas durante a sua construção do texto.

Sugerimos que os operadores são essas marcas capazes de prenunciar a existência de uma estrutura usual e que alguma dimensão do enunciado no intervalo pontuado por eles pode representar algum padrão para um determinado gênero.

Se os operadores têm as qualidades acima apontadas, resta-nos compreender que tipo de estruturas estariam sendo ligadas por eles.

Para efeito desta pesquisa, consideramos essas estruturas como blocos semânticos, tal qual faz a Teoria dos Topoi.

Para a Teoria dos Topoi, a palavra é definida como um 'feixe de topoi' $^{14}$ (paquet de topoi) (DUCROT, 1995), ou seja, o seu sentido é constituído por um conjunto vago de possibilidades de encadeamentos discursivos. Dessa forma, como fontes de discurso, as palavras viabilizam

\footnotetext{
${ }^{14}$ Tradução proposta por Heronides Moura quando dirigiu a entrevista concedida por Oswald Ducrot e Marion Carel transcrita para a revista DELTA em 1997.
} 
a construção do texto e, como integrantes da argumentação, permitem observar a dinâmica do encadeamento do discurso.

O papel de um operador ${ }^{15}$ é, genericamente, concorrer para estabelecer relações explícitas ou implícitas dos encadeamentos argumentativos.

Como a argumentação faz parte da composição de diferentes gêneros do discurso, o papel coesivo dos operadores pode ser estendido para além do âmbito da dissertação.

Da mesma forma que um texto é construído por uma língua histórica, cujos registros remetem à história de seus textos, os gêneros também se consolidam pela sua realização social e mantêm com os contextos em que são empregados um forte elo referencial.

A existência de um gênero num texto traz consigo inferências a respeito de que tipos de interação existem entre enunciador e enunciatário e já faz antever uma série de possibilidades para o desenvolvimento da interação, bem como, supostamente, excluir todo um outro desencadeamento que não pertença ao escopo desse gênero.

\footnotetext{
${ }^{15}$ MAINGUENEAU (1997, p. 160) considera os conectivos como os morfemas que têm por função ligar dois enunciados.
} 
É com base na combinatória dos gêneros que se estabelece o fluxo das relações dialógicas presentes na enunciação e a maneira de expressão dos acentos de valor consagrados pela cultura.

Assim sendo, se existir algum padrão relacionado à ocorrência de operadores nos textos, esse padrão deve se estender a uma gama ampla de gêneros, ainda que quantitativamente diferente entre eles.

Para efeito desta pesquisa, consideramos os operadores como as marcas, cuja função é sinalizar a constituição de um gênero e, pretensamente, induzir o leitor a acreditar que ali existe um texto e obter dele a colaboração necessária para que faça a sua interpretação.

Os operadores são também os elementos cujo emprego participa das instruções

dadas àqueles que deverão interpretar um enunciado da frase, solicitando-lhes que procurem, na situação de discurso este ou aquele tipo de informação para utilizá-la desta ou daquela maneira para reconstruir o sentido visado pelo locutor. (DUCROT, 1980, p. 12)

Em se considerando que os operadores atuam como marcas de gênero e de ligação entre os blocos constituintes de um texto, é tentador supor que, no texto escrito, apresenta uma natureza multifuncional 
similar à dos marcadores conversacionais ${ }^{16}$ no texto oral, ainda que sob restrições mais severas, típicas da formatação do texto escrito.

Seria essa uma explicação para o emprego inadequado de grande variedade de operadores, quando é notável que não se está respeitando o seu valor lógico-argumentativo intrínseco. Tal qual observado por BARROS (2003, p.3), quando relata que, ao usarem o operador embora, os alunos do Ensino Fundamental e os do Ensino Médio revelam, através da escrita, o desconhecimento do valor desse item, tanto no plano sintático, quanto no plano semântico.

Subentendemos que a precedência temporal em desempenhar o texto oral faz com que algumas estratégias de sua constituição venham a ser aplicadas no texto escrito, fato esse que nos mostra que a inadequação apontada acima pode ser justificada pela multifuncionalidade que o operador assume enquanto marca da enunciação para facilitar a leitura.

Os operadores organizam, por sua vez, a argumentação, não apenas pela introdução do valor desse item nos planos sintático e semântico, mas também pelo seu papel pontuando os blocos, sugerindo, durante a leitura, que esses blocos podem estar inseridos num tecido de

${ }^{16}$ MARCUSCHI (1989, p. 282) diz que os marcadores conversacionais são palavras e expressões mais ou menos fixas, características da fala, elementos que operam, simultaneamente, como organizadores de interação, articuladores do texto e indicadores da força ilocutória, sendo, pois, multifuncionais. Considera os marcadores conversacionais como dotados de propriedades interacionais (na condução dos atos ilocutórios e das relações interpessoais) e de propriedades intratextuais (na estruturação da cadeia lingüística). 
natureza argumentativa, fazendo antever o gênero em que se inscreve o referido texto, permitindo que o leitor enunciatário consiga encontrar ou não o turno para a sua indagação. A manipulação do texto assim descrita facilita a dissipação das dúvidas e ambigüidades decorrentes do emprego inadequado dos operadores.

Talvez coubesse melhor considerar que, apesar de o emprego ser inadequado quanto ao valor lógico-argumentativo, outras funções podem estar sendo cumpridas por aquele operador, as quais permitem facilitar a tarefa de leitura do texto, administrando as interações do leitor / texto e das vozes dos vários textos. Nota-se que a similaridade entre os papéis do marcador conversacional e do operador deriva dos aspectos comuns da construção textual que ocorrem no texto escrito e no texto oral, e estão sob as rédeas do gênero que se busca, conforme sugere MACHADO:

A fala não se opõe à escritura. Pelo contrário, a diversidade e a interrelação entre gêneros do discurso enriqueceu e tornou muito mais complexa a textualidade tanto a oral quanto a escrita. Neste sentido, o discurso é o espaço vivo do texto e centro dinamizador dos gêneros.... (MACHADO; 1999:55) 
Pelo fato de ser a modelagem matemática desta pesquisa baseada

numa função arbitrária ${ }^{17}$ de escolha de operadores a serem

contabilizados, apresentamos, como exemplo, alguns dos que podem ser

etiquetados :

Operadores que indicam o argumento mais forte de uma série ${ }^{18}$;

Operadores que somam $\operatorname{argumentos}^{19}$;

Operadores que introduzem uma conclusão $0^{20}$;

Operadores que introduzem argumento contrário ${ }^{21}$;

Operadores que introduzem uma explicação ${ }^{22}$;

Operadores que introduzem argumentos alternativos $^{23}$;

Operadores que estabelecem relações de comparação ${ }^{24}$. (KOCH;

1992)

${ }^{17}$ Isso decorre do fato de a função não ter de ser uma função ótima.

${ }^{18}$ Os produtos daquela fábrica são de uma qualidade excepcional. Conquistaram o mercado inteiro, o Mercosul e até (até mesmo, inclusive) o exigente mercado europeu.

${ }^{19}$ Aquela faculdade oferece os melhores cursos. Não só tem infraestrutura completa, como também tem um corpo docente altamente qualificado. Além disso, obteve conceito A em todas as avaliações do MEC.

${ }^{20}$ Os rios estão cada vez mais poluídos. As alterações climáticas e o desmatamento têm feito diminuir as chuvas. O uso desordenado e irracional dos recursos hídricos vem causando uma diminuição nos níveis de reserva da água. Portanto (logo, conseqüentemente, assim) pode-se dizer que, em poucos anos, grande da população sofrerá com a falta de água potável.

${ }^{21}$ A equipe venceu o jogo, mas não agradou a torcida. O governo agiu energicamente. No entanto, não conseguiu acalmar o mercado financeiro. Embora tenha agido energicamente, o governo não conseguiu acalmar o mercado financeiro.

${ }^{22}$ Prefiro usar o computador, pois (porque) os resultados são mais eficientes.

${ }^{23}$ Você vai tomar uma atitude em ou vai deixar a vida passar em branco?

${ }^{24}$ Este governo é melhor do que o outro. 
Apontamos os operadores como nosso objeto de atenção, em virtude de serem elementos da estrutura léxico-sintática do texto com propriedades relacionadas à construção de sua tessitura, cujo algoritmo, a ser descrito oportunamente, ao fazer uso de sua freqüência relativa de ocorrência, poderá buscar formas de correlacioná-la à potencialidade de coesão e coerência de um conjunto de enunciados. 


\subsection{Coesão e Coerência}

Coesão e coerência são propriedades inerentes ao texto, sem as quais não restam meios para se considerar os enunciados como compondo uma integralidade.

Talvez por parecerem conceitos primitivos oriundos da experiência empírica, torna-se difícil defini-los e diferenciá-los.

Para o nosso estudo, consideraremos esses conceitos como dois níveis distintos de análise, tal qual o faz a maioria dos autores cujas idéias exporemos.

Os estudos realizados pela Lingüística Textual, surgidos na década de 60, diferentemente da abordagem desenvolvida até então, cujo objeto de estudo era a frase, caracterizaram-se pela busca de aspectos que definissem padrões de textualidade.

Em primeira instância, vigorou a análise transfrástica na qual ainda não se estabeleciam critérios de diferenciação para a coesão e coerência.

Na década seguinte, inspiradas na gramática gerativa, surgem as “gramáticas de textos", preocupadas com os princípios constitutivos do 
texto numa língua, as condições para a edificação da tessitura e as relações que poderiam ser observadas nas diferenciações dos tipos de texto.

Sob a influência da Pragmática, as Teorias do Texto passam a compreender texto e contexto como objeto de análise. Em torno de 1980, surgem abordagens que consideram as condições externas ao texto como também relevantes na sua significação.

Os estudos de Halliday e Hassan fazem parte do conjunto de abordagens designadas como Teorias do Texto, diferenciando-se das demais por preconizarem que o processamento do texto se dá pela interdependência dos elementos que o constituem, definindo-se pelas relações de sentido estabelecidas em seu interior. Concluem, assim, que a textualidade está relacionada a fatores de coesão.

Halliday e Hassan definem coesão como um conceito semântico, relativo às relações de significado existentes no texto e que o definem como tal. A coesão resulta da combinação da articulação gramatical do emprego vocabular, o que denominam coesão gramatical e coesão lexical.

Para os autores, a textura, a qualidade que caracteriza um texto, envolve, além das relações semânticas descritas pela coesão, aquelas estabelecidas entre o discurso e o contexto de situação e as decorrentes das formas de influência do falante na situação de fala. 
As relações estabelecidas entre o extrato do discurso e o contexto de situação promovem o discurso à condição de consistente em registro. Já a coerência oriunda das formas de influência do falante na situação de fala inclui os componentes interpessoais (social, expressivo, conotativo) os moods, modalidades e intensidades.

Convém lembrar que as modalidades correspondem ao ponto de vista do locutor em relação à situação comunicativa e, portanto, às relações do locutor com os valores transmitidos por seu discurso.

Pode-se dizer que, segundo esse modelo, o ato comunicativo compõe-se de um conteúdo proposicional e de uma atitude subjetiva inserida no discurso do locutor. Surgem, dessa maneira, "marcas" nas expressões modais capazes de orientar o fluxo de argumentação do discurso.

Essas "marcas modais" podem ser encontradas lexicalizadas num discurso de várias maneiras: performativos explícitos, auxiliares modais, predicados cristalizados, advérbios modalizadores, formas verbais perifrásicas, modos e tempos verbais, verbos de atitude proposicional, operadores argumentativos, entonação.

A textura resulta da combinação de configurações semânticas de dois tipos: 
a ) registro: corresponde àquelas configurações semânticas que estão associadas a classes específicas de contexto de situação, responsáveis pela significação do texto, no seu sentido mais amplo, incluindo todos os componentes do seu significado, como social, expressivo, comunicativo, representacional etc..

b) coesão: representada por uma série de relações de significado que é geral para todas as classes de textos e que os distingue do que não é texto; então, não está voltada para o que um texto significa, mas para como está edificado semanticamente.

De maneira distinta, Charolles aborda a questão da coesão e coerência textuais: não usa o termo coesão e, para a coerência, faz a distinção entre o que considera microestrutural, que diz respeito às relações de coerência entre as frases, e o que considera macroestrutural, relativa às relações de coerência entre seqüências.

Existem quatro metarregras de coerência que estabelecem as condições para que se forme uma cadeia de representações semânticas organizadas. Referem-se tanto à coerência do tipo macroestrutural quanto microestrutural. 
Metarregra de repetição: estabelece que os elementos de recorrência estrita devem estar presentes no desenvolvimento linear do texto. São exemplos desses elementos as pronominações, as definitizações lexicais, as retomadas de inferências. Pelo mecanismo proposto por essa regra, tem-se o desenvolvimento temático contínuo do enunciado. (CHAROLLES, 1978, p. 20)

A repetição mais comum ocorre para léxicos distintos com carga semântica próxima, a substituição sinonímica. Entretanto, faz-se substituição lexical, ainda que não com a mesma freqüência, pelo uso de hiperônimos, hipônimos e das palavras gerais. Trata-se de repetições que expandem, mantêm ou restringem o objeto sobre o que fala o tópico do texto e atribuem a ele, por comparação entre as cargas semânticas do primeiro e dos substitutos, novas propriedades que facilitam a progressão. Assim, pode-se ter repetição léxico por léxico e léxico por enunciado, pois o que importa é a relação de intersecção da carga semântica. 
No primeiro caso, a substituição pode ser feita por nominalização, substituição de formas verbais por nomes ${ }^{25}$, ou por elipse, na qual o substituto é zero ${ }^{26}$.

Pode-se dizer que:

Se a forma elíptica é um meio de recuperação das dependências, o que dizer da natureza dessas dependências?

Pode-se formular, entre outras, a seguinte hipótese: o exame das elipses justifica-se não pelo que lhes falta, mas pelo que elas mostram _ raciocínio que nos leva a concluir que as elipses consistem menos em suprimir do que em articular.

Articular o quê? Texto e contexto, ou seja, referentes textuais e referentes situacionais.

Aí o seu papel de poderoso fator de coerência do texto. (GUIMARÃES, 2001, p. 35)

Os termos também podem contar com uma repetição sob a forma de um enunciado capaz de fazer uma recapitulação enunciativa, ao que se dá o nome de anáfora conceitual.

Metarregra de progressão: estabelece ser necessária a renovação constante da carga semântica no desenvolvimento do texto para que esse possa pleitear-se coerente. (CHAROLLES, 1978, p. 21)

\footnotetext{
${ }^{25}$ Exemplo: Os que se sentirem lesados poderão pedir revisão de suas indenizações. Os pedidos serão avaliados segundo critérios já divulgados.

${ }^{26}$ Exemplo: As crianças viram a fera e......... fugiram.
} 
Metarregra da não-contradição: afirma ser preciso que não haja a introdução de nenhum elemento semântico que contradiga um conteúdo posto ou pressuposto por uma ocorrência anterior ou dedutível por inferência. (CHAROLLES, 1978, p. 22)

Metarregra de relação: afirma que, para que uma seqüência ou um texto sejam coerentes, é preciso que os fatos que denotam no mundo representado estejam relacionados. (CHAROLLES; 1978:31)

Essas regras são apenas um certo número de condições, tanto lógicas como pragmáticas, que um texto deve satisfazer para ser conhecido como bem formado (por um dado receptor, numa dada situação). Assim, faz-se necessário que se levem em conta os parâmetros pragmáticos nos quais se inserem os participantes do ato de comunicação textual, para que um texto seja avaliado em sua coerência.

Por essa concepção,

...parece que não é possível tecnicamente operar uma divisão rigorosa entre as regras de porte textual e as regras de porte discursivo. As gramáticas do texto rompem as fronteiras geralmente admitidas entre a semântica e a pragmática, entre o imanente e o situacional, donde, de nosso ponto de vista, a inutilidade de uma distinção entre coesão e 
coerência que alguns propõem baseando-se justamente na divisão precisa entre esses dois territórios... (CHAROLLES, 1978, p. 11)

Enquanto Halliday e Hassan definem coesão e coerência de forma relativamente estanque e Charolles julga inútil uma distinção entre elas, estabelecendo, sem dar demarcação clara, dois níveis (microcoerência e macrocoerência), Widdowson articula coesão e coerência, considerando que a primeira dá possibilidade de inferir os atos ilocucionais a partir das ligações proposicionais indicadas explicitamente e que a segunda dá meios de deduzir as ligações proposicionais implícitas a partir de uma interpretação dos atos ilocucionais.

Para Widdowson, é possível construir textos desprovidos de marcas de coesão, mas dotados de coerência ${ }^{27}$, pois o produtor do discurso fornece tantos índices quantos julga necessários para realizar a comunicação, levando em conta o quanto supõe que o interlocutor pode deduzir do seu discurso.

\footnotetext{
${ }^{27}$ Exemplo: A: A água do macarrão já está fervendo.

B: Estou no quintal cuidando dos cachorros. A: Está bem. Reconstituição das ligações:

A: A água do macarrão já está fervendo. (Você pode colocá-lo na água.)

B: (Não posso fazê-lo pois) Estou no quintal cuidando dos cachorros.

A: Está bem. (Eu o farei.)
} 
Convém notar que algumas seqüências de enunciados, apesar de não apresentarem marcas de coesão, possuem clara relação de dependência, que torna o significado do todo muito mais rico do que a simples adição de informações de cada enunciado individualmente. Como mostra Garcia (1972, p.18):

... muitas vezes, um período só aparentemente é coordenado. Vejamos outros casos, examinando os três pares de frases seguintes:

a) Não fui à festa do seu aniversário: não me convidaram.

b) Não fui à festa do seu aniversário: passei-lhe um telegrama.

c) Não fui à festa do seu aniversário: não posso saber quem estava lá.

São frases construídas segundo o processo particular da ordenação chamado justaposição: orações não ligadas por conectivo, separadas na fala por uma ligeira pausa com entoação variável, marcada na escrita por vírgula, ponto-e-vírgula ou dois-pontos.

É outro caso de coordenação ou justaposição gramatical, mas de subordinação psicológica, tanto é certo que o segundo elemento de cada par de frases não goza de autonomia de sentindo. A relação entre as duas orações de cada período é de dependência, nitidamente insinuada pelos dois pontos na escrita, e na fala, por uma entonação da voz.... (GARCIA; 1972, p. 18) 
É importante notar que a suposição do produtor não garante a reconstituição do interlocutor, mas se existir, de fato, a suficiência de índices esperada, essa reconstituição se dará apesar da ausência das marcas explícitas. Assim, pode-se afirmar que:

Onde podemos estabelecer uma ligação proposicional entre as frases, sem consideração dos atos ilocucionais em questão, referindo-nos a índices formais sintáticos e semânticos, constatamos a coesão. A coesão é portanto a relação explícita entre as proposições expressas pelas frases. Onde reconhecemos a existência de uma relação entre atos ilocucionais que as proposições realizam (os quais podem estar ligados de forma não explícita) percebemos a coerência do discurso... uma vez que há coesão é possível inferir os atos ilocucionais a partir das ligações proposicionais indicadas explicitamente, e inferir as ligações proposicionais a partir de uma interpretação dos atos ilocucionais. (Widdowson; 1981, p. 39)

O fato de existirem casos em que a ausência de marcas coesivas não afeta a coerência textual permite-nos esperar a ocorrência de leituras com avaliação positiva ainda quando os textos têm uma freqüência relativa de operadores inferior à média encontrada na amostra.

Consideramos, entretanto, que a afirmação de Widdowson, apesar de verdadeira, corresponde a um conjunto de eventos com baixa probabilidade de ocorrência no universo da construção textual escrita. 
Koch também considera coesão e coerência como fenômenos de natureza distinta, reconhecendo, contudo, a existência de zonas mais ou menos amplas de imbricação entre eles, nas quais a separação entre eles pode se tornar impraticável.

Para Koch, coesão corresponde à maneira como os elementos lingüísticos encontram-se interligados para a composição do sentido:

Podemos conceituar a coesão como o fenômeno que diz respeito ao modo como os elementos lingüísticos presentes na superfície textual se encontram interligados, por meio de recursos também lingüísticos, formando seqüências veiculadoras de sentido. (Koch, 2000, p. 35)

Para a autora, a coesão apresenta-se sob duas modalidades: a remissão e a seqüenciação. A primeira modalidade desempenha tanto a função de (re)ativação de referentes quanto a de sinalização textual.

Como reativação de referentes, compreende as referenciações anafórica e catafórica, por meio das quais se formam cadeias coesivas de extensão variável, sendo que aquelas que retomam referenciais principais ou temáticos percorrem, em geral, o texto inteiro.

A remissão por referenciações pode ocorrer por meio de recursos de ordem gramatical ou por intermédio de recursos de natureza lexical.

Podem ser descritos como recursos de ordem gramatical: 
- uso de pronomes pessoais de terceira pessoa $\left(\operatorname{retos}^{28}\right.$ e oblíquos) e dos demais pronomes (possessivos, demonstrativos, indefinidos, interrogativos, relativos);

- uso dos diversos tipos de numerais;

- usos dos advérbios pronominais (como aqui, aí, lá e ali);

- uso de artigos definidos.

Podem ser listados como recursos de natureza lexical:

- uso de sinônimos;

- uso de hiperônimos;

- uso de hipônimos;

- uso de nomes genéricos;

- uso de descrições definidas;

- uso da reiteração completa ou parcial de um grupo nominal;

- uso da elipse.

É importante ressaltar que, muitas vezes, a reativação de referentes é promovida por "indícios" ou "pistas" deixadas no texto, escritório. 
capazes de gerar inferências ${ }^{29}$. Essas remissões podem ser realizadas pelo processo diafórico que compreende a anáfora e a catáfora.

A anáfora pode ser exemplificada pelo texto adiante:

Havia, enfim, umas duas ou três senhoras, vários gamenhos, e os fâmulos, que naturalmente se desforravam assim da condição servil, $e$ tudo isso constituia uma verdadeira floresta de olheiros e escutas, por entre os quais tínhamos de resvalar com essa tática e maciez das cobras. ${ }^{30}$

Um exemplo de catáfora pode ser visto abaixo:

Resolveu renunciar a tudo: amor, dinheiro e fama.

Sobre a sinalização textual, afirma a autora:

A "sinalização textual" tem função básica de organizar o texto, fornecendo ao interlocutor apoios para o processamento textual, através de "orientações" ou indicações para cima e baixo (no texto escrito), para a frente e para trás, ou partes do texto.

A autora considera que a sinalização corresponderia, portanto, a uma dêixis textual, o que coaduna com a posição de EHLICH (1981), que

${ }^{29}$ Exemplo: “...As galas do momento faziam sorrir a paisagem. O arvoredo do imenso jardim, entretecido a cores por mil bandeiras,..." Raul Pompéia in: O Ateneu.

${ }^{30}$ ASSIS, Machado de. Memórias Póstumas de Brás Cubas. São Paulo. Editora Ática. 1987. p.81 
considera que as expressões dêiticas permitem, pela condução do enfoque para itens específicos por parte do produtor do texto, organizar-se a atenção dos interlocutores.

A coesão seqüenciadora responde pela propriedade de continuidade dos sentidos que compõe, pela fluência que faz parecer ter o texto, com a qual se lhe possa dar prosseguimento.

Já a coerência, segundo a autora, é o modo como os elementos subjacentes à superfície textual vêm constituir uma configuração veiculadora de sentidos para os interlocutores.

A coerência se estabelece em diversos níveis: sintático, semântico, temático, estilístico, ilocucional, concorrendo todos eles para a construção da coerência global. (KOCH; 2000:41)

Na mesma linha de raciocínio, os estudos de Van Dijk centram-se nas macroestruturas textuais e superestruturas (ou esquemas) textuais. Para defini-las, considera que a coerência é uma propriedade semântica dos discursos, baseada na interpretação de cada frase individual relacionada com a interpretação de outras frases. 
A noção de conectividade corresponde, então, a um aspecto da coerência discursiva, aquele que diz respeito à concatenação de proposições de tal forma que possam ser tomadas como um todo.

Ressalta, contudo, que

Las frases o proposiciones en un discurso pueden formar un discurso coherente, sin embargo, incluso si no están todas conectadas con todas las otras frases o proposiciones. En particular, pueden estar relacionadas en pares sin estar conectadas en el sentido definido anteriormente, por ejemplo cuando existem relaciones entre partes de dos o más proposiciones. (VAN DIJK; 1998, 147)

O nexo entre frases ou discursos pode se dar pela relação de Identidade Referencial, que decorre da existência de um valor comum (indivíduo ou propriedade) a várias proposições distintas. Esse liame pode estar explícito ou implícito, como afirma o autor:

El discurso de la lengua natural, frente al discurso formal, no es plenamente EXPLÍCITO. Las relaciones entre frase y proposiciones pueden existir sin que se expressen. Esta es la razón por la que la construcción teórica de un TEXTO es necesaria para mostrar cómo los discursos pueden interpretarse coherentemente incluso si la mayor parte de las proposiciones necesarias para establecer la coherencia permanecen IMPLÍCITAS, por ejemplo cómo las proposiciones 
vinculadas de proposiciones expresadas explícitamente en el discurso. (VAN DIJK; 1998, 148)

Os dois casos citados acima não podem ser detectados pelo nosso processo de busca de padrão pela freqüência relativa de operadores, pois, em se tratando de Identidade Referencial, o processo pode se dar à custa de elementos nominais que não sejam operadores, e, em se lidando com blocos implícitos de proposições, pode ocorrer de os operadores estarem implícitos também. Para corrigirmos esse possível desvio, teríamos de incluir, de um lado, os itens referenciais e, de outro, até elementos de pontuação, quando o papel por eles realizado é o de sinalizar uma operação em que o operador está implícito.

Para o fato relatado no parágrafo anterior, usamos a hipótese de que o desvio entre o valor esperado da freqüiência relativa dos operadores e a frequiência relativa empírica média da amostra, para textos considerados coerentes, tende a ser desprezível para grandes números.

Como o nosso enfoque é identificar e verificar a frequiência relativa dos operadores responsáveis pela ligação entre blocos textuais, apresentamos a forma pela qual esse autor sugere que se estabelece a coesão: 
Hemos usado el término <<conexión>> para referimos a una relación específica entre frases. Estrictamente hablando, sin embargo, la frases son objetos sintácticos, y si la conexión es una noción semántica, como suponemos, deberíamos hablar más bien de PROPOSICIONES conectadas. Las frases y secuenciais de frases pueden EXPRESAR tal relación entre proposiciones, por ejemplo, por CONECTIVOS de varias categorias sintáticas (conjunciones, advérbios, partículas). Si hablamos de frases (o cláusulas) conectadas, nos referimos a oraciones cuyas proposiciones <<subyacentes $>>$ están conectadas. La propriedad de una serie de proposiciones que están conectadas se llamará CONECTIVIDAD o Conexión. Otro término que se usa también en la lógica reciente es el de PERTINenCiA (relevance). Este término, sin embargo, lo reservaremos para referirnos a ciertas propriedades pragmáticas de las frases o proposiciones, $\mathrm{o}$ sea a un cierto aspecto de su adecuación (apropriateness) en un texto comunicativo. (VAN DIJK, 1998, 83)

Pela semântica da coerência, o autor define, então, o que chama de coerência linear ou seqüiencial como a que se mantém entre proposições expressas por orações compostas e seqüências de orações; e o que denomina macroestruturas como aquelas que determinam a coerência global ou de um discurso e estão determinadas em si mesmas pela coerência linear das sequiências (VAN DIJK, 1998, 150-151). 


\subsection{Leitura e Avaliação}

O modelo estratégico de Van Dijk e Kintsch considera a leitura como um processo não orientado por níveis progressivos: morfológico, sintático, semântico e pragmático, mas sim regido pela interação decorrente da troca de feedback (VAN DIJK e KINTSCH, 1983).

Segundo esse modelo, o leitor pode processar as informações disponíveis, hierarquizando-as, de forma distinta, de acordo com o seu propósito, com o seu conhecimento prévio, da coerência necessária à compreensão.

O modelo estratégico baseia-se na hipótese de que, durante a leitura, constrói-se, por parte do leitor, uma representação mental dos eventos lidos. Dessa maneira, afirma como um pressuposto, ao qual se atribui o nome de construtivista, que os efeitos na memória desse processo de construção são responsáveis pela compreensão.

Quando se refere aos eventos lidos, o modelo não aponta para uma representação dos dados lingüísticos, mas sim para uma interpretação desses dados - pressuposto interpretativo. 
Dizem os autores que a construção de um significado para os dados utilizados como input ocorre de forma simultânea e interligada ao processamento desses dados, o que chamam de pressuposto on-line.

Ao fato de dados cognitivos pré-existentes, como conhecimento prévio do leitor, suas experiências, suas crenças etc., influenciarem a compreensão textual deram o nome de pressuposto pressuposicional (pressuppositional assumption).

Para completar o elenco de pressupostos cognitivos do modelo e dar-lhes consistência, tem-se o pressuposto estratégico, que afirma que as estratégias de abordagem são alternadas pelo leitor visando a suprir as necessidades que surgem durante a leitura. Destarte, não há um procedimento padrão para a utilização das várias informações à medida que se executa a leitura: o leitor se apropria, relaciona e utiliza os vários tipos de informação de maneira flexível para cumprir a sua tarefa.

No mesmo patamar de importância dos pressupostos cognitivos, que listamos acima, estão os pressupostos contextuais, nos quais se reúnem todos os pressupostos que expressam a influência do contexto sociocultural em que está inserida a realização do discurso, a saber: pressuposto de funcionalidade, pressuposto pragmático, pressuposto interacionista e pressuposto situacional. 
O pressuposto de funcionalidade corresponde ao como as dimensões sociais do discurso interagem com as dimensões cognitivas e, conseqüentemente, ao como se constrói a representação resultante da integração das representações do texto e do contexto social que o abarca.

O pressuposto pragmático refere-se à inferência que faz o leitor à significação conforme os possíveis atos de fala envolvidos no texto. Já a interpretação do discurso como um ou mais atos de fala de um processo interacional geral desenvolvido pelos vários participantes é considerada como o pressuposto interacionista.

O pressuposto situacional é aquele que afirma ser a interação uma realização social, sujeita a normas e valores estabelecidos no âmbito social, atitudes e convenções que agem sobre os participantes e sobre as interações numa dada situação.

Dessa maneira, esse modelo prega que o processo de leitura resulta da construção de representações dos atos de fala, das interações comunicativas e da situação, bem como da forma com que elas interagem com a compreensão do discurso.

Em virtude de serem os pressupostos aplicados à mercê das estratégias adotadas pelo leitor, conforme se desenvolve o processo de leitura, conclui-se que, para esses autores, a compreensão não é uma mera 
construção passiva de uma representação do objeto lingüístico, mas parte de um processo interativo no qual um leitor interpreta, ativamente, as ações de um autor.

Por outro lado, a importância da palavra, do input lingüístico, para a construção do significado é menosprezada frente aos componentes extrínsecos de processamento da informação semântica e, portanto, o seu papel como marca capaz de desencadear escolhas de estratégias de leitura capazes de melhorar o desempenho do processo de interpretação é ignorado.

Como as estratégias adotadas se diferenciam, dado um mesmo texto, conforme se muda de leitor, não parece fazer sentido a restrição ao campo de interpretações possíveis.

A avaliação de um texto em função do que experimentou o leitor ao praticar a leitura de um texto passa a ser, praticamente, apenas subjetiva, tendo em vista que não há procedimento padrão para a utilização das várias informações à medida que se executa a leitura.

É interessante notar que Van Dijk e Kintch (1983) sugerem que não existe, durante o processo de leitura, a exploração paralela de organizações textuais alternativas, dentre as macroestruturas possíveis. 
O trabalho experimental de Terzi corrobora a suposição desses

autores:

Os dados deste livro mostram que as crianças, embora leitoras ainda não-proficientes, também se engajam numa única interpretação. Porém, num momento mais inicial, como o descrito anteriormente, elas não conseguem, mesmo diante do conflito, abandonar essa interpretação em prol de uma outra mais adequada. (TERZI, 2002, p.105)

Van Dijk e Kintch (1983) mostram estratégias que fomentam a compreensão dos textos e que situam o leitor devidamente aparelhado diante da leitura. Sugere que o leitor ideal assume um papel ativo perante ela.

Assim, a leitura é um processo de emissão e verificação de previsões que levam à construção da compreensão do texto. A compreensão de um texto envolve a capacidade de elaborar um resumo, que reproduz seu significado global de forma sucinta (Van Dijk, 1983).

A composição do resumo exige a capacidade de "poder diferenciar o que constitui o essencial do texto e o que pode ser 
considerado em um determinado momento - para alguns objetivos concretos - como secundários" (SOLÉ, 1998, p. 115).

A manutenção do ritmo da leitura e, portanto, do estabelecimento efetivo da coesão proposta pelo autor, exige que o leitor tenha um comportamento contínuo de fazer previsões. Essas previsões dão uma noção do todo, quando parte da leitura ainda não está realizada e, na seqüência da leitura, permite que se faça a comparação entre o esperado e aquilo que, de fato, o texto propõe.

Assim, para que o leitor seja efetivamente um leitor ativo que compreende o que lê, deve poder fazer algumas previsões com relação ao texto; também vimos que algumas características do texto - a superestrutura ou tipo de texto, sua organização, algumas marcas etc. -, assim como os títulos, as ilustrações que, às vezes, os acompanham e as informações abordadas pelo professor, por outros alunos e pelo próprio leitor, constituíam o "material" que gerava essas hipóteses ou previsões. Estas previsões, antecipações, ou seja, lá o que for, devem ser compatíveis com o texto, ou ser substituídas por outras. Quando estas são encontradas, a informação do texto integrase aos conhecimentos do leitor e a compreensão acontece (SOLÉ, 1998, p. 115). 
Segundo a autora, os leitores experientes não só compreendem, mas também sabem quando não compreendem e, no último caso, podem realizar ações que lhes permitam preencher uma possível lacuna de compreensão.

Solé denomina metacognitiva a atividade de avaliação da própria compreensão, que acontece, à medida que se processa a leitura, ao se fazerem previsões, formularem-se perguntas, recapitular-se e resumir-se a informação: todas as atitudes que indicam o estado de alerta perante possíveis incoerências ou desajustes.

Em termos lexico-sintáticos, o texto escrito tem de favorecer a sua compreensão para compensar a ausência de informações de natureza supra-segmental. Conforme afirma Charmeux:

Em um texto escrito, o leitor, que tem de construir o sentido sozinho, tem necessidade de muitas indicações e de muitas nuanças para evitar contra-sensos, e penetrar nas intenções de comunicação daquele que escreve. Daí a necessidade de uma armadura lógica precisa, que explicite com o máximo de firmeza as relações que unem entre elas as diversas proposições do texto (CHARMEUX, 2000, p. 65). 
Por ser um meio de relacionamento entre o indivíduo e o texto oriundo de uma prática social, o processo de leitura só encontra êxito se o leitor é capaz de compreender os diversos textos que tem à disposição e que se propõe a ler. $O$ sucesso desse processo decorre, necessariamente, de se chegar a uma interpretação daqueles que escolheu.

A realização da leitura parte das expectativas do leitor, das perguntas que formula, das dúvidas que lhe ocorrem, como chega à conclusão do que é fundamental para os objetivos que o guiam, da escolha dos elementos que toma ou não do texto, do que já conhecia e do que apreende durante a leitura, em suma, das estratégias que assume ou que costuma executar em seu modelo de leitura.

Não se pode desconsiderar o papel da motivação para a consecução dessa atividade, pois se trata de um percurso informacional ponteado de decisões do leitor, para o qual a chegada à interpretação só pode ser constatada no final do processo. É, portanto, necessário que o interesse do leitor seja renovado, passo a passo. Um texto deve, então, apresentar recursos para evitar o estancamento da passagem do fluido motivacional de uma etapa decisória para outra que lhe segue.

Dessa forma, apesar de a coerência e a coesão estarem relacionadas à composição de uma unidade de significação a partir do 
total enunciado, devem existir indícios no texto que, durante a leitura, sinalizem ao leitor a perspectiva positiva de que se conseguirá atingir uma interpretação. Trata-se, se considerarmos a leitura como um processo dialógico, de a voz do texto garantir o retorno ao seu turno e fazer a manutenção desse turno até que o leitor possa invadi-lo novamente com os seus questionamentos ou retomadas. $O$ processo de disputa e manutenção de turno que, na oralidade, é pontuado pelos marcadores conversacionais, possui, na leitura de um texto escrito, o suporte da pontuação e dos operadores.

Um leitor fluente para um dado tema cobra, durante a leitura, momentos em que possa ter uma participação ativa e condições para que possa retornar para a voz do texto com a grata sensação de continuidade.

O conhecimento do que Frank Smith (1975) chama de informações não-visuais, as referentes da competência lingüística de cada leitor e as relativas à temática, associa-se àquele de natureza visual (organização das letras na página), para estabelecer-se a fluência da leitura.

Além, portanto, da fluência cognitiva, uma outra oriunda do próprio mecanismo de leitura permite que se estabeleça uma seqüência de apreensão de blocos. 
Está claro que há uma relação inversa entre a informação não-visual utilizável e a informação visual requerida. Smith e outros autores nos lembram dados já clássicos da psicologia experimental de laboratório: o olho não trabalha senão "a saltos"; cada fixação dura aproximadamente 250 milissegundos, logo realiza um salto" de aproximadamente 10/12 letras (ou espaço equivalentes), e se detém outra vez, para uma nova fixação. Há, além disso, retorno para trás, saltos mais importantes no final de uma linha, etc. Em cada fixação identificam-se 4 ou 5 itens diferentes: se o estimulo visual consiste em letras apresentadas ao azar, serão 4 ou 5 letras diferentes; se o estimulo consiste em palavras escritas, pode-se identificar o dobro de letras que antes (duas palavras, aproximadamente 10 letras); se as palavras estão organizadas sintaticamente (isto é, constituem uma oração escrita), podemos identificar o dobro de letras que antes (em torno de 4 palavras, quer dizer aproximadamente 20 letras) (FERRERO; TEBEROVSKY, 1991, p. 269 - 270).

Ocorre que a organização sintática, a ordem dos elementos de uma oração, é mais facilmente depreensível se houver uma pontuação conveniente. Para isso, também colaboram marcas capazes de estruturar os blocos semânticos. 
O mecanismo próprio de leitura exige que se organize o estímulo visual com o que se aufere cognitivamente.

O que "se vê" depende, então, do nível de organização do estímulo. Porém, na realidade, não é que o olho veja mais coisas, mas que a capacidade de integração da informação aumenta concomitantemente com a organização do estímulo. Em outras palavras, o leitor completa com sua inteligência não-visual (conhecimento do léxico e da estrutura gramatical de sua língua) a escassa informação visual recolhida numa centração (FERRERO; TEBEROVSKY, 1991, p. 270).

Dessa forma, enquanto Van Dijk e Kintch focam os pressupostos interpretativos como fundamentais para o desenrolar da fluência leitora, Frank Smith (1975) baseia-se na predição léxico-semântica e na predição sintática.

As predições são basicamente de dois tipos diferentes: predições léxico-semânticas que nos permitirem antecipar o significado tanto como proceder a autocorreções, e predições sintáticas, que nos permitem antecipar a categoria sintática de um termo, tanto como proceder a autocorreções quando elemento sintático essencial não foi 
identificado. Um exemplo de predições do primeiro tipo é o seguinte: lendo rapidamente as manchetes de um jornal (uma atividade de leitura na qual qualquer leitor adulto, por mais que seja, costuma cometer erros de identificação) um adulto acredita identificar a oração "liberaram-se os preços do peixe"; a incongruência semântica é evidente, e o leitor volta atrás, ao único lugar onde poderia existir um erro de identificação (“preços.”). Um exemplo do segundo tipo de predição é a experiência conhecida de qualquer leitor adulto de chegar ao ponto final da oração sem ter encontrado um verbo; tipicamente, neste caso, o conhecimento sintático força uma autocorreção e uma nova exploração (FERRERO; TEBEROVSKY, 1991, p. 270).

Compreende-se, então, que as condições em que se dá a leitura podem alterar a capacidade de interpretação do leitor e, por conseguinte, a sua avaliação sobre a qualidade dela.

Situações de interesse especial para a nossa pesquisa podem ser esperadas, em se relacionando a constituição da interpretação e coerência textual, a partir do modelo de Van Dijk, conforme segue:

...a coerência está diretamente ligada à possibilidade de se estabelecer um sentido para o texto, ou seja, ela é o que faz com que o texto faça sentido para os usuários, devendo, portanto, ser 
entendida como um princípio de interpretabilidade, ligada à inteligibilidade do texto numa situação de comunicação e à capacidade que o receptor tem para calcular o sentido deste texto. Este sentido, evidentemente, deve ser do todo, pois a coerência é global. ... (KOCH e TRAVAGLIA, 2000, 21)

Assim, a coerência de um texto depende do processo de leitura e, por conseqüiência, das estratégias adotadas pelo leitor: um texto que teve sua interpretação realizada por um leitor e, em contrapartida, uma interpretação nula por outro, poderia ser considerado coerente pelo primeiro e sem coerência para o segundo.

Se o fato citado acima é possível de ocorrer, perguntamo-nos o que faz com que seja, estatisticamente, irrelevante, quando os leitores respondem igualmente bem aos pressupostos requisitados? O que faz com que, por exemplo, possamos avaliar as redações escolares e, desta maneira, classificá-las, sem que exista um incontável número de contestações?

Também se faz notar que, diante da pluralidade de interpretações possíveis para um determinado texto, não se encontrem textos cuja interpretação seja completamente aberta.

Em suma, dizer que um texto é potencialmente sem fim não significa que todo ato de interpretação possa ter um final feliz. Até mesmo o 
desconstrucionista mais radical aceita a idéia de que existem interpretações clamorosamente inaceitáveis. Isso significa que o texto interpretado impõe restrições a seus intérpretes. Os limites da interpretação coincidem com os direitos do texto (o que não quer dizer que coincidam com os direitos de seu autor). (ECO, 2000, XXII)

Essa constatação empírica nos sugere que o processo de interpretação realizado pelo leitor não esteja sujeito a um procedimento de escolhas fortuitas ou intuitivas ou mesmo de natureza individual de estratégias, mas conduzido, de alguma forma, pelo texto.

Entretanto, o caminho percorrido pela leitura e aquele desenhado pela significação, apesar de atrelados ao texto, não são necessariamente iguais para leitores distintos, ou mesmo para o leitor que faça a leitura em diferentes momentos, com outras estratégias e conhecimentos.

Como a verificação de coesão e coerência só se pode fazer no nível semântico, a qualidade da leitura passa a ser crucial para a avaliação final. Portanto, é difícil se fazer uma avaliação objetiva sobre coesão e coerência.

Quando afirmamos que é impossível fazer uma avaliação objetiva sobre coesão e coerência, não queremos dizer que é impossível 
avaliar essas características do texto. Apenas achamos inviável que de algo sujeito ao subjetivismo da percepção e da compreensão se possa extrair uma avaliação quantitativa e exata e, portanto, indiscutível.

De fato, nesta pesquisa, em um total de 338 redações apenas $6,51 \%$ tiveram atribuídas notas iguais por todos os professores, $0,89 \%$ com notas iguais de todos os professores e da avaliadora de formação média $^{31}$. Por outro lado, não mais do que $5,02 \%$ tiveram notas que julgamos discrepantes ${ }^{32}$.

Isso sugere que dois fenômenos concomitantes agem sobre a leitura: a individualidade de proceder do leitor e a base comum oferecida pelo texto.

Nota-se, também, que, em $76 \%$ das discrepâncias, havia uma quantidade acima da média de conexões implícitas encontrada no grupo de melhor avaliação, o que nos permite supor que o aumento de elementos pressupostos faz com que a individualidade do procedimento do leitor ganhe preponderância sobre a base textual comum.

\footnotetext{
${ }^{31}$ A probabilidade para 4 notas aleatórias construídas de um conjunto $\{00 ; 05 ; 10 ; 15 ; 20 ; \ldots ; 100\}$ serem iguais é de, aproximadamente, $0,0002 \%$, enquanto que, para 3 notas serem iguais nas mesmas condições, é de, aproximadamente, $0,003 \%$.

${ }^{32}$ Um conjunto de notas foi considerado discrepante, quando a amplitude (a diferença entre a maior nota e a menor nota atribuídas) fosse maior do que 3 , ou seja, maior do que $30 \%$ do intervalo válido.
} 


\section{Abaixo está um exemplo ${ }^{33}$ de texto cujas notas foram consideradas discrepantes:}

\section{Redação no. 19}

\section{Nota máxima: 7,0 Nota mínima: 3,0}

Existem alguns indicadores para que os jovens usem entorpecentes

Sabemos que a falta de estrutura na família, o desemprego e a baixa auto-estima, são os principais pontos que levam qualquer jovem é usar droga, além das amizades.

Isso acontece porque não tendo emprego e nem apoio familiar os jovens acabam envolvendo-se com pessoas estranhas, roubando e até matando para poder usar drogas. Pois se os mesmos não têm apoio da família vão procurar apoio nos estranhos que não os cobram nada. Deve-se levar em conta que para a formação do caráter do adolescente é imprescindível o apoio familiar.

Porém os meios de comunicação e até as histórias que os jovens escutam, só os levam a crer que, as drogas os levará a dois caminhos: cadeia ou suicídio.

Então fica a pergunta.

Se eles sabem que as drogas não são o melhor caminho para a vida, então porque continuam se suicidando?

Jovens a vida é uma só, precisamos cuidar bem dela.

\section{Comentário}

\section{Algumas proposições implícitas podem ser levantadas por}

\section{questões feitas ao texto, como:}

\footnotetext{
${ }^{33}$ Fazemos uso de exemplos desta pesquisa para poder ilustrar o aparato teórico que utilizamos.
} 
a) O que e quais seriam os indicadores?

b) Quais são as histórias que os jovens escutam?

c) Como os jovens ficam sabendo que as drogas não são o melhor caminho?

\section{Redação no. 22}

Nota máxima: 8,5 Nota mínima: 5,0

É cada vez maior o número de jovens que se envolvem com drogas na adolescência acarretando para aqueles que o cercam, transtornos irreparáveis na maioria das vezes.

Os especialistas atribuem a este problema muitas causas e dentre elas há uma que é cada vez exaltada: a desestruturação familiar - uma família desestruturada empurra o jovem para fora de casa e este vai procurar na rua, entre os amigos, uma maneira de superar a falta de equilíbrio que existe em casa.. Assim encontra a droga e quando se dá conta de que arrumou mais problema, muitas vezes já é tarde demais.

As famílias devem estar sempre atentas a situações que podem excluir o jovem do seio do lar. Ter a noção de que a família é base de tudo que o jovem será pelo resto de sua vida.

\section{Comentário}

Algumas proposições implícitas podem ser levantadas por questões feitas ao texto, como:

\section{a. Quais são os transtornos irreparáveis?}


b. Como encontra a droga?

c. Por que é importante ter a noção de que família é a base de tudo o que o jovem será pelo resto da vida?

\section{Redação no. 16}

Notas Atribuídas: 3,0; 3,0; 3,0.

A principal causa que leva um jovem a usar drogas é o medo de não fazer parte do grupo em destaque entre as demais pessoas.

O jovem que está sempre no auge da fama e para isso ele tem que praticar e usar tudo o que é moda dentro de seu convívio pessoal

Geralmente os mais bem vistos como atraentes, ousados e diferentes, conhecem ou usam drogas e desta forma passa a meio impor um padrão geral para os que quiserem fazer parte de seu grupo a partir daí começa um círculo vicioso, que leva a morte.

Esse tipo tem como causa a dependência orgânica e a exclusão do grupo social.

\section{Comentário}

Um elemento implícito por elipse pode ser descoberto depois de uma leitura atenta do texto, como podemos observar no trecho abaixo:

Esse tipo tem como causa a dependência orgânica e a exclusão do grupo social. 
Tanto o conhecimento prévio de que as drogas causam dependência, quanto à relação estabelecida pelo texto entre droga e ciclo vicioso são fontes de informação capazes de preencher a lacuna de significado compatível.

A redação $n^{0} 16$ requisita poucos pressupostos e peca, principalmente, por explicitar uma visão estereotipada da questão, tendo como recurso de expressão a sucessão de paráfrases.

\section{Redação n 32}

Notas Atribuídas: 6,0; 6,5; 7,0.

Segundo estatísticas atuais, o consumo de drogas no país cresce estrondosamente, entre os jovens de todas as classes sociais. Tal fator está relacionado com a conduta desse grupo, pois eles estão mais propensos ao consumo. Para comprovar os dados é necessário observar os grupos de relacionamento entre os jovens e a curiosidade por novidades.

Um jovem quando começa a estabelecer relacionamentos, sente a necessidade também de ser aceito por certos grupos e até mesmo de uma pessoa que ele admira. Tal necessidade os leva a fazer coisas que não gostam, mas para serem reconhecidos pelo grupo. E dessa maneira muitos ingressam no mundo das drogas.

Outro fator é a curiosidade inerente dessa idade e tal curiosidade os leva a ver as drogas como um mundo a ser descoberto, algo que os fará muito importante. Porém muitos entram nesse mundo e não voltam mais. 
Em vista desses fatores, podemos perceber o porque do consumo acelerado entre os jovens e só podemos esperar que a família desses indivíduos procurem ajuda o quanto mais rápido possível, pois se não agirem, seus filhos podem morrer a qualquer instante.

\section{Comentário}

Uma proposição implícita pode ser percebida quando se faz a seguinte pergunta ao texto: por que "só" podemos esperar que a família desses indivíduos procurem ajuda? Por que não nos cabe outra tarefa?

Ao falar sobre a conduta do jovem, deixa-a implícita como um elemento pressuposto conhecido pelo leitor, o que, contudo, será retomado e esclarecido nos parágrafos seguintes.

Note-se que a redação $n^{0} 32$ progride na informação que fornece, apresentando pouca requisição de elementos implícitos.

Concluímos, dos exemplos apresentados, que, além de o enfrentamento da leitura, com diferentes estratégias e subsídios culturais, resultar em múltiplas apreciações, a dificuldade de se engendrarem critérios objetivos para a avaliação da coesão e da coerência colabora para que exista a variação das notas atribuídas para um texto comum. 
Cabe dizer que, em termos gerais, uma avaliação classificatória ou objetiva vê o conteúdo a ser verificado como um conjunto estanque de informações objetivas.

Esse tipo de avaliação busca fazer a medida de aproveitamento relacionando o que o aluno acerta com aquilo que deveria acertar. Se a natureza da construção do texto é tão subjetiva quanto a sua leitura apreciativa, é inevitável que a avaliação textual, quando revestida de objetividade, apresente uma flutuação dos valores das notas dos examinadores.

Segundo Hoffman, não se podem medir os fenômenos que não possuem precisão numérica para tal.

Assim, nem todos os fenômenos podem ser medidos, por não haver instrumentos para tanto, ou por não admitirem tal precisão numérica. (Felizmente, os cientistas ainda não fabricaram instrumentos para medir o amor ou a tristeza e outros sentimentos humanos). Podemos medir, na escola, a freqüência às aulas, por exemplo. (Elemento sempre presente nos regimentos escolares) Ou podemos medir (contar) o número de acertos em uma tarefa de livros lidos ou de trabalhos entregues. 
Mas o que se percebe é que os professores não definem o termo medida com essa clareza. E muito menos o utilizam nesse sentido. $O$ que acontece é, então, a atribuição de graus numéricos a vários aspectos relacionados à vida do aluno na escola, indiscriminadamente. Decorre, desse equívoco, a atribuição de notas a aspectos atitudinais dos estudantes (comprometendo, interesse, participação) ou a tarefas deles que não admitem escores precisos (redações, desenhos, monografias) (HOFFMANN, 2006, p. 40).

Perrenoud considera que os processos de avaliação, quaisquer que sejam, estão submetidos ao limite da qualidade e aplicabilidade das informações coletadas.

Porque que a regulação dos processos de aprendizagem é, freqüente, pouco eficaz? Porque o professor nem sempre consegue otimizar sua avaliação e suas intervenções. Para garantir uma regulação efetiva das aprendizagens ele deveria dispor de informações pertinentes e confiáveis, interpretá-las corretamente, em tempo hábil, imaginar constantemente uma intervenção apropriada e conduzi-la de modo eficaz... Ora, é uma mente humana, com todas suas ambigüidades e limites, que capta a informação e interpreta, concebe a intervenção e a orienta. Mesmo instrumentadas, racionalizadas, codificadas, otimizadas, assistidas por computador, a avaliação e a intervenção 
são, em ultima instância, operações e ações realizadas por seres humanos. Além disso, eles nem sempre estão em situação de refletir e de agir tranqüilamente, dada a urgência e a incerteza que caracterizam o ofício de professor (Perrenoud, 1996c).Cada professor está comprometido com interações densas e complexas no seio de um grupo, ele próprio inserido em uma organização impositiva. (PERRENOUD, 1999, p. 80)

Afirma Perrenaud (1999) que se estabelecem as notas e os conceitos por métodos impressionistas ou por comparação, incorrendo em arbitrariedades. Se se assumir, sem ressalvas, a sua análise sobre a avaliação objetiva, chega-se a inutilizar completamente a atribuição de notas para redações.

A questão é que fazer uma avaliação objetiva requer critérios objetivos; se é quantitativa, variáveis que se reduzam a valores numéricos. O problema que decorre do modus operandi da objetividade é que muito do que se avalia hoje, nos textos, não é incorreção, mas inadequação. Não se está sumamente preocupado com a ortografia, mas sim com a coesão, a coerência, a adequação ao tema e outras variáveis que pertencem ao âmbito da semântica, logo, subjetivas. 
Nos antigos manuais de estilo e redação, propunha-se o desconto de nota por "incorreção" encontrada no texto da redação. Para cada observação, um item surgia na legenda de comentários. Ainda hoje, em alguns cursos de prática de redação para ensino virtual, faz-se uso de um procedimento análogo.

Em 2003, para uma das disciplinas voltadas para a prática de redação de uma instituição de ensino superior, foi desenvolvida uma legenda para agilizar a correção por parte dos professores mediadores, pois centenas de redações chegavam todas as semanas, para que cada corretor pudesse atuar sobre elas e, em seguida, submetê-las de volta, por meio da plataforma, ao respectivo aluno remetente.

Tratava-se, ao empregar uma legenda comum, de facilitar a correção na tela, tornando-a mais ágil, mais homogênea entre os corretores e, inevitavelmente, mais objetiva.

Essas providências mostraram-se eficazes para o que se destinavam, porém pecavam por não respeitar o foco principal daquilo que se previa nos objetivos declarados da ementa da disciplina, dentre eles, fazer "entender as relações entre expressão e conteúdo, os mecanismos de estruturação e interpretação de textos". 
Tais objetivos não podiam estar contemplados nessa forma de avaliação, pois envolvem parâmetros subjetivos. Para melhor compreensão da limitação assinalada, segue abaixo a tabela de correção e três exemplos de redações corrigidas pelo processo acima descrito:

\section{TABELA DE OBSERVAÇÕES}

1 Coloque sempre um título, centralizando-o sem aspas.

2 Faça parágrafos distando mais ou menos $3 \mathrm{~cm}$ da margem. Alinhe as margens.

3 Evite linguagem coloquial. No texto dissertativo, emprega-se norma culta.

4 Escreva de forma impessoal. Não se posicione em primeira pessoa do singular.

5 Evite dirigir-se diretamente ao leitor e aos textos dados como apoio.

6 Evite construir períodos longos, que podem tornar-se confusos.

7 Evite expressões ambíguas (aquelas que possibilitam dupla interpretação).

8 Evite frases muito curtas. Procure uni-las a outras por meio de conectivos (conjunções, preposições, pronomes e advérbios).

9 Evite repetições. Diversifique seu vocabulário

10 Evite desviar-se do tema. Não faça narração, crônica ou descrição.

11 Evite introduções e desenvolvimentos que nada acrescentem ao texto.

12 Evite rodeios: procure ser objetivo

13 Evite interrogações no meio ou na conclusão do texto dissertativo.

14 Evite empregar reticências e etc no texto dissertativo.

15 Não abrevie palavras no texto dissertativo.

16 Evite empregar sinais que são próprios da comunicação digital no texto dissertativo. 


\section{Redação:}

Nota: 3,0

\section{[1]}

[2]Eu acho [4]que essa coisa[3] de rede de internet vai ser um bom negócio[3] [se utilizada pelas] (se expandir para as) escolas públicas, já que as particulares já possuem essa infraestrutura [infra-estrutura] já [9] bem avançada.

[2]Com essa tecnologia[,] as pessoas vão poder ser mais capazes[15] de ter um emprego escolaridade

bom pela frente, porque [,]de agora em diante [,]quem não tiver uma

boa e um Inglês [7]e uma informática [7] é [será] um analfabeto completo. Por mais que

a pessoa seja pobre [,]ela tem o direito e o dever de ter um computadorzinho[3]

em casa, nem que seja um 486 conectado à internet.

[2]Bom,[3] esse é o meu modo de ver [4]as coisas,[3] embora tem [haja] pessoas [3]que são contra a informatização das escolas, falam que poderia atrofiar[15] o conhecimento

das crianças.

\section{Redação:}

Nota: 5,0

A carroça na frente dos bois

nos nossos dias.

Não podemos negar que a Internet tem uma importância fundamenta

Hoje em dia [,]quase tudo é baseado[15] na Internet. Nós conseguimos até fazer transações bancárias com um simples clicar de mouse.

Isto tudo acontece em uma sociedade em que cada vez mais os jovens tem[têm] vantagens sobre os de mais idade, [11] devido a está [esta] geração ter nascido em meio às transformações tecnológicas, com muito mais acesso a [à] área de computação dos [do] que os [as gerações mais velhas.] (mais antigos) .

Diante deste quadro de transformações, o governo quer que tenha pontos para o acesso da[à] Internet em vários pontos [9] da cidade. Isto é uma idéia fantástica [3] , mas primeiro o governo deve investir (em levar esta tecnologia até) as [nas] escolas [,quipando-as dessa tecnologia], partindo do princípio que quem não estiver plugado na Internet, estará certamente fora de mercado[ qual?]. 


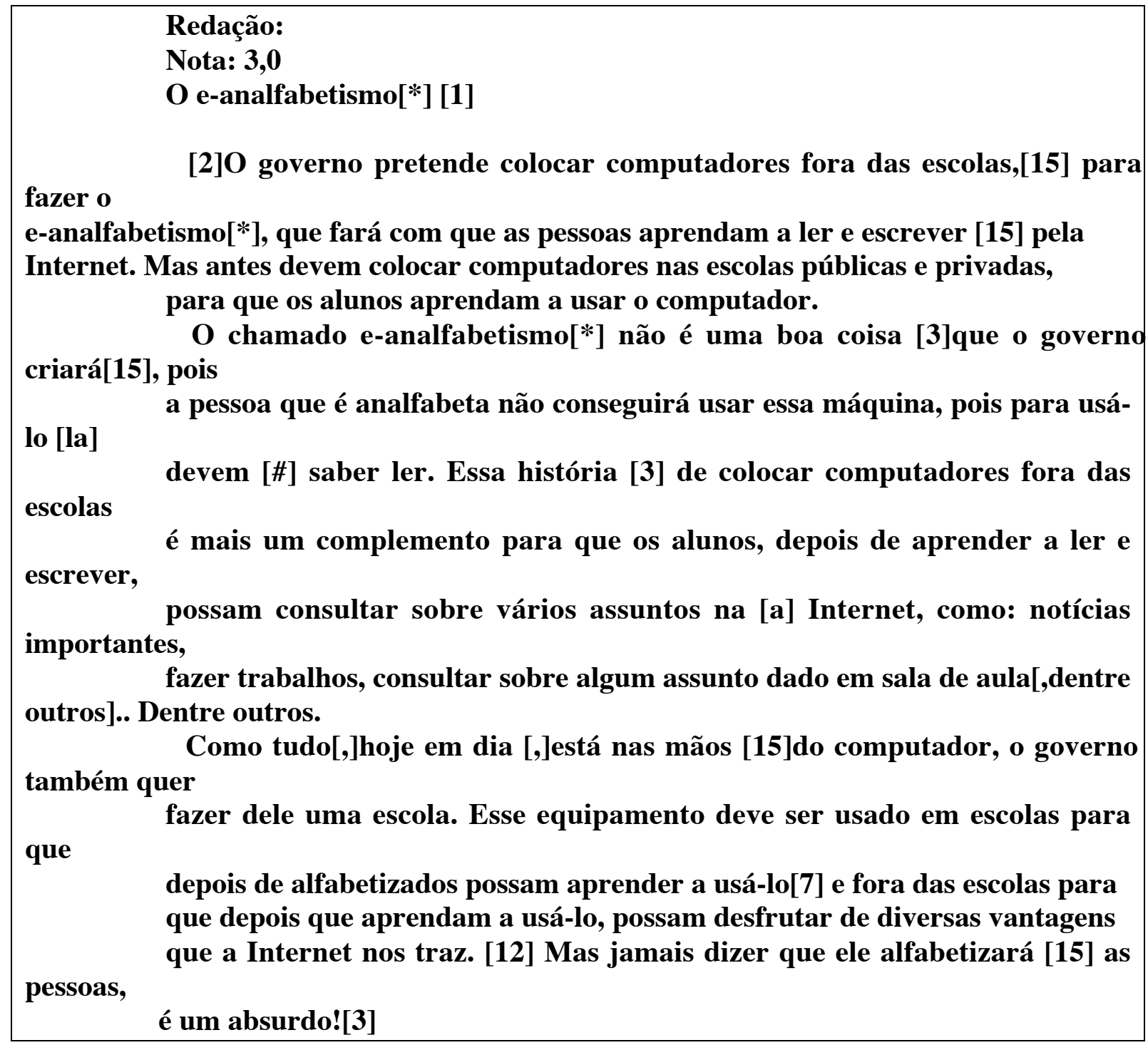

Pode-se notar que todas as redações apresentam obstáculos à progressão da temática abordada, mas, em nenhum momento, as indicações baseadas na tabela foram capazes de, sequer, induzir o aluno a compreender a problemática de coesão e coerência do seu texto. 
Também pode ser ressaltado que, conforme o conjunto de instruções que embasam um determinado gênero, a maneira como se fazem constituir a coesão e a coerência pode ser mais ou menos intensa. Um telegrama quase não apresenta operadores, mas é muito coerente e centrado num tópico temático; já um e-mail despreocupado pode não apresentar, apenas em seu corpo textual, nem coerência nem estar centrado numa temática, como se nota no exemplo abaixo:

<asrtagtol.com.br>

Desculpe-me ñ ter respondido na sexta, mas tivemos um problema com o servidor, e foi impossível. (tecnologia!!!!)

Minhas férias!!!! Isso é só fachada, muito trabalho, dor de cabeça e pouca festa!! rs...

Escreva mais sobre vc...

Qnto ao brinde, tem este tel. 98iyut nos dias úteis das 9 às 17:30.

Torna-se necessário, portanto, um paradigma que norteie o processo de avaliação da coesão e da coerência textual frente à variedade de gêneros praticados. 
Atualmente, um modelo vem sendo apresentado por aqueles que defendem o interacionismo sociodiscursivo, desenvolvido pelos pesquisadores da Faculdade de Psicologia e Ciências da Educação da Universidade de Genebra.

De acordo com esse modelo, a produção de um texto empírico resulta de observação de algumas condições que, nos termos de Bronckart (1999, p.91-195), formam uma base de orientações construídas de dois grandes componentes: a) a definição de parâmetros acerca da situação de comunicação, constituída pela mobilização de representações dos mundos físico - o lugar e o momento da produção, o emissor e o receptor - e sócio- subjetivo - a intuição social onde se dá a interação, o papel social representado pelo enunciador e pelo destinatário e o objeto da interação; e b) a definição do conteúdo temático - conjunto de conhecimento dos mundos físicos e social estocados e organizados na memória do produtor do texto.

A construção dessa base de orientação pelo produtor de texto controla as formas de gestão e verbalização do texto, que está vinculado a um gênero, ou seja, a uma forma relativamente estável de escrever, elaborada sócio-historicamente por uma das diferentes esferas das atividades humanas. Nesse sentido, o planejamento se apresenta como a operação central e inicial de gestão e verbalização 
de um texto. Atreladas ao planejamento se encontram as operações infraestruturais do texto, compreendendo a escolha da organização seqüencial e dos mecanismos locais de textualização (coesão, conexão e modalização), todas em função do gênero representativo da interação social em curso (REINALDO; SANTANA, 2005, p. 102103).

A expressão gestão textual está relacionada à habilidade de revisar e reescrever o texto, o que, pela natureza desta pesquisa ${ }^{34}$, não pode estar no escopo do critério de avaliação adotado.

Consideramos, então, que conhecer os critérios que já se encontram em uso para situações de concurso é fundamental para esclarecer o como se estabeleceu o conjunto aplicado pelos professores que fizeram parte da banca avaliadora desta pesquisa.

\section{THEREZO resume o bom texto como}

aquele que apresentar os cinco recursos de eficiência textual: adequação ao tema solicitado, adequação ao tipo de composição, adequação ao nível de linguagem (determinado pelo tema, pelo tipo de composição e pelo receptor em situação de interação); coesão e coerência, fundamentadas na clareza. (THEREZO, 1997, p. 10)

\footnotetext{
${ }^{34}$ Este trabalho não tem natureza longitudinal e, portanto, não pretende observar a discrepância em relação ao desempenho de um mesmo aluno em circunstâncias diferentes.
} 
São parâmetros para os critérios adotados por Therezo para uma planilha de avaliação voltada para o Ensino Médio:
a) tema;
b) tipo de composição;
c) nível de linguagem;
d) coesão;
e) coerência.

A ausência de um detalhamento que explicitasse uma forma mais clara com que se poderia auferir a coesão e coerência pode ser sanada pelos critérios de VAL (1991), que destrincha esses dois parâmetros como se segue:

1. Coerência:
a) continuidade;
b) progressão;
c) não-contradição interna;
d) não-contradição externa;
e) articulação;
f) presença;
g) pertinência. 


\section{Coesão:}
a) continuidade;
b) progressão;
c) não-contradição;
d) articulação.

3. Informatividade:
a) suficiência de dados;
b) imprevisibilidade.

Os critérios para esta pesquisa, com base nesses autores, objetivam dar valor ao que se entende por mais ou menos coerente em uma construção textual ${ }^{35}$. 
Fundamentação da Modelagem Estatístico-Computacional 


\section{Fundamentação da Modelagem Estatístico-Computacional}

\subsection{O Método de André Camlong}

O método de Camlong caracteriza-se por, primeiramente, um instrumento computacional - o programa Stablex desenvolvido com o algoritmo do método —, que discrimina os vocábulos encontrados nos textos (estes chamados de variáveis) e indica os respectivos números de ocorrências. Logo após essa etapa, de cujo resultado obtemos uma tabela de distribuição de freqüências, oferece uma segunda tabela referente aos desvios reduzidos $z_{i j}$ (em que 'j' é o índice das variáveis e 'i', dos vocábulos).

Para compreender o significado de $\mathrm{z}_{\mathrm{ij}}$, é conveniente notar que, sendo $a_{i j} 0$ elemento da matriz $T_{i x} j$ de distribuição de freqüências TDF, vale a definição:

$$
z_{i j}=\frac{a_{i j}-p_{j} \cdot \sum_{j} a_{i j}}{\sqrt{p_{i} \cdot q_{i} \sum_{j} a_{i j}}}
$$

De tal sorte que: 


$$
p_{j}=\frac{\sum_{i} a_{i j}}{\sum_{i} \sum_{j} a_{i j}} \quad \text { e } \quad q_{j}=1-p_{j}
$$

O significado de $p_{\mathrm{j}}$ corresponde à relação de tamanho entre o conjunto de ocorrências da variável ' $j$ ' no total de ocorrências e representa a probabilidade dessa variável; sendo assim, $q_{j}$ é a sua probabilidade complementar.

Pode-se notar que o numerador do desvio reduzido corresponde à diferença entre a ocorrência efetiva de determinado vocábulo numa variável e aquela esperada, segundo a probabilidade dessa variável, frente o total desse mesmo vocábulo. Disso decorre que, quando o resultado for positivo, a ocorrência efetiva é superior à esperada e vice-versa.

Já o denominador corresponde ao desvio padrão para distribuições normais: daí o cuidado de se restringir o espaço da distribuição que garanta a normalidade ${ }^{36}$.

A TDR (tabela de desvios reduzidos) fornece subsídios para o cálculo dos pesos lexicais de cada variável e a TDF (tabela de distribuição de freqüências) permite avaliar o índice de correlação entre as variáveis.

${ }^{36}$ É importante notar que quanto mais assimétricas forem as dimensões entre as variáveis, menor será o valor absoluto resultante no denominador. 
O cálculo do peso lexical de uma variável 'j’, aqui representado

por $P_{j}$, é feito da forma que se segue:

$$
P_{j}=\sum_{i} Z_{i j}
$$

A correlação entre variáveis num conjunto de dados brutos, como os encontrados na TDF, mede a dependência linear entre as variáveis (MAGALHÃES:2001;142) e é calculada da forma que se apresenta:

$$
\rho_{x, y}=\frac{\sum_{i=1}^{n}\left(a_{i x}-\bar{a}_{x}\right) \sum_{i=1}^{n}\left(a_{i y}-\bar{a}_{y}\right)}{\sqrt{\left[\sum_{j=1}^{n}\left(a_{j x}-\bar{a}_{x}\right)^{2}\right]\left[\sum_{j=1}^{n}\left(a_{j y}-\bar{a}_{y}\right)^{p}\right]}} \quad \text { onde: }
$$

'n' corresponde ao número de linhas de freqüência de vocábulos encontrados das duas variáveis, quando da correlação simples. No caso da correlação múltipla, corresponde ao número total de linhas geral;

' $x$ ';' $y$ ' correspondem às variáveis escolhidas. ${ }^{37}$

\footnotetext{
${ }^{37}$ As notações matemáticas não seguiram àquelas do formalismo do autor, mas sim ao que se estabelece em álgebra linear, para facilitar o desenvolvimento de novos algoritmos engendrados em pesquisas computacionais dispostas a obter novas relações entre os dados obtidos dos textos.
} 
A equação acima pode ser expressa através da covariância como se segue:

$$
\rho_{X, Y}=\operatorname{Cov}(X, Y) / \sigma_{X} \cdot \sigma_{Y}
$$

\section{Como}

$$
\operatorname{Cov}(X, Y)=E(X Y)-E(X) \cdot E(Y)
$$

Pode-se observar que, no caso em que $X$ e $Y$ sejam independentes, temos $\operatorname{Cov}(X, Y)=0$, uma vez que o valor esperado do produto se torna igual ao produto dos valores esperados. Assim definida, pode-se notar que a correlação é uma medida de dependência linear.

Aproximando-se da unidade, a correlação obtida entre as variáveis —que a cada uma é dada a condição de representar uma redação - indica uma proximidade entre a variável em questão e uma média geral. 
En conclusion: le calcul du coefficient de corrélation suffit donc à déterminer les taux d'intensité et de densité de liaision des lexiques autour des moyennes générales ${ }^{38}$ (CAMLONG, 1996, p. 90).

Podemos considerar essa proximidade como se os textos apresentassem um grau de coesão entre si, estabelecida por uma interrelação textual por configuração lexical encontrada.

Como os itens lexicais se estruturam em função da unidade de sentido do texto, dentre os mecanismos de coesão do texto, destaca-se a coesão lexical, que concorre para a construção do referente, da temática e dos efeitos de sentido que o locutor deseja produzir (ZAPPAROLI, 2002, p.151).

Assim, essa medida será utilizada para retirarmos de um conjunto inicial de redações as que apresentam o valor absoluto de correlação abaixo de 0,85 ; de tal forma que o grupo que segue para análise possa ser considerado mais homogêneo entre si, para uma mesma proposta de atividade.

Tal pressuposto baseia-se na característica imanente ao Método:

${ }^{38}$ Em conclusão: O cálculo do coeficiente de correlação é suficiente, portanto, para determinar as taxas de intensidade e de densidade de ligação dos léxicos em torno das médias gerais. 
Enfatiza-se, ainda, que o valor de cada item lexical e de cada variável é apurado no jogo da intertextualidade (ou do interdiscurso), na articulação entre a unidade e o todo, visto a técnica da estatística descritiva revelar o valor qualitativo dos itens lexicais não apenas no interior do texto em que estão inseridos, mas também em relação ao conjunto de textos que constituem o corpus de análise - é o diálogo constante entre os textos que determina o peso de cada variável e do corpus. São as relações intratexto e intertextos que geram os valores dos itens lexicais na composição do texto e do discurso que o texto veicula, daí os resultados da análise lexical fornecerem muitos indicativos para a análise textual e discursiva. O corpus é concebido, portanto, como uma organização de textos que dialogam entre si, como um texto maior em que cada texto se integra e cada item lexical adquire seu valor, seu peso (Zapparoli, 2002, p. 152).

O procedimento de filtragem visa a, de forma empírica, reduzir os possíveis fatores de ruído sobre o teste de hipótese, buscando diferenciar os textos apenas segundo as freqüências relativas dos operadores neles encontrados. 


\subsection{Inferência Estatística}

O conjunto de técnicas que tem como objetivo o estudo de uma população por meio de evidências fornecidas por uma amostra é conhecido como inferência estatística.

$O$ fato de as quantidades associadas à amostra terem caráter aleatório obriga a fazer uso de tratamento probabilístico, o que não seria necessário se a amostra fosse constituída de todos os elementos da população.

Para o nosso trabalho, o parâmetro (quantidade desconhecida da população, sobre a qual temos interesse) é a média das freqüências relativas dos operadores, que representaremos como $\mu$.

A estimativa desse parâmetro será feita usando duas amostras de redações que foram selecionadas, conforme o conceito que lhes foi atribuído pela banca examinadora ${ }^{39}$.

A primeira preocupação quando tratamos com um estimador é verificar se é consistente, ou seja, se satisfaz as seguintes propriedades:

a) o seu valor esperado coincide com o parâmetro de interesse;

\footnotetext{
${ }^{39}$ Os detalhes estão apresentados nos Procedimentos Metodógicos.
} 
b) a variância tende a zero, quando se aumenta o número de elementos da amostra.

Convém lembrar três características de uma distribuição amostral de médias:

1. A distribuição de médias amostrais aproxima-se de uma curva normal. Isso é verdade para todas as distribuições de médias amostrais independentemente da forma da distribuição dos escores brutos que constituem a população da qual as médias foram extraídas ${ }^{40}$.

2. A média de uma distribuição de médias amostrais ("a média das médias") é igual à verdadeira média populacional. Se tomarmos um grande número de médias amostrais casuais da mesma população e calcularmos a média de todas elas, obteremos o valor da verdadeira média populacional.

3. O desvio padrão de uma distribuição de médias amostrais é menor do que o desvio padrão da população. padronizada, se comporta segundo um modelo Normal com média 0 e variância 1 . 


\subsection{Comparação de Média para Duas Populações}

Nesta pesquisa, estamos interessados em comparar duas populações em relação às suas médias. As duas amostras usadas para esse fim são independentes, pois as redações ali contidas são de autores diferentes.

Partimos da hipótese nula representada pela suposição de que as médias populacionais são iguais.

As amostras cujas médias queremos comparar não têm as variâncias conhecidas. Para esse caso, a quantidade a ser usada para o teste será:

$$
\mathrm{T}=\left[\mathrm{D}-\left(\mu_{\mathrm{x}}-\mu_{\mathrm{y}}\right)\right] /\left(\mathrm{S}_{\mathrm{x}}{ }^{2} / \mathrm{n}_{1}+\mathrm{S}_{\mathrm{x}}{ }^{2} / \mathrm{n}_{1}\right)^{1 / 2}
$$

Por se tratar de uma distribuição t-Student, em que a variância também está sendo estimada, os graus de liberdade a serem considerados deverão sofrer uma correção feita pelo parâmetro $v$.

Digamos que não se conheça o comportamento com que se manifesta a característica de interesse na população, neste caso, sugere-se dispor os dados relativos às amostras tal qual está a seguir: 


\begin{tabular}{|l|l|l|}
\hline Grupo & Amostra & $\begin{array}{l}\text { Proporção de Ocorrência do Evento em } \\
\text { Relação à Totalidade dos Casos }\end{array}$ \\
\hline I & A1 & P1 \\
\hline II & A2 & P2 \\
\hline
\end{tabular}

Dessa forma, para saber se os dois grupos acima têm o mesmo comportamento, quanto à incidência da característica de interesse, podemos realizar um teste de hipóteses envolvendo proporções.

Para uma amostra suficientemente grande, sabemos, pelo Teorema Central do Limite, que a distribuição de probabilidade da proporção amostral tem um comportamento aproximadamente igual ao modelo Normal ${ }^{41}$.

A fim de compararmos as proporções em duas populações, usaremos como estimador a diferença entre as respectivas proporções amostrais (MAGALHÃES; LIMA, 2004, p. 310).

Supondo que duas amostras independentes foram retiradas, uma em cada população, teremos duas proporções amostrais independentes, e a diferença entre elas também terá distribuição aproximadamente Normal.

${ }^{41} \mathrm{O}$ tamanho da amostra pode ser avaliado pela conseqüência direta da Lei Fraca dos Grandes Números (SILVA, 1998, p. 97). 
Procedimento Metodológico 


\section{Procedimento Metodológico}

\subsection{Constituição do Corpus}

O corpus desta pesquisa foi obtido a partir de propostas de práticas de redação realizadas em instituições de ensino. Parte das redações foi produzida e submetida em meio digital. Outras foram entregues para avaliação em mídia papel.

Os temas das propostas de redação foram:

a) o uso de drogas pelos jovens: as suas possíveis causas e conseqüências;

b) a importância da leitura para os jovens;

c) a linguagem escrita e alta tecnologia;

d) a inclusão digital e internet;

e) o modo de vida nas metrópoles.

Os textos foram agrupados conforme a proposta de trabalho a que se referiam. 
As redações escritas em papel foram coletadas e, a seguir digitadas, de forma que não se fizesse intervenção sobre o texto ${ }^{42}$.

Cada redação em papel passou a ter, por correspondência, uma redação digital, um registro num banco de dados e, para esse registro, os dados relativos aos campos nota, proposta de atividade, data, professor e um código de identificação do aluno autor.

42 Apesar de haver a preocupação com a integridade do conteúdo das redações, convém lembrar que os erros ortográficos têm influência desprezível para o procedimento desta pesquisa. O baixo significado dos erros ortográficos para a obtenção dos resultados é devido às verificações manuais dos resultados dos processamentos que porventura fossem sensíveis a eles e ao fato de se trabalhar com um conjunto muito estrito de lexias. 


\subsection{Tratamento do Corpus}

Todas as redações foram destinadas a três professores com incumbência de fazer a sua avaliação, baseando-se, para essa tarefa, em critérios comuns e pré-estabelecidos.

A definição dos critérios foi norteada pelos objetivos desta pesquisa, mas também contou com a contribuição de teóricos, conforme está na Fundamentação Teórica.

A diferença básica dos critérios aqui adotados em relação aos demais aplicados em exames de seleção $^{43}$ é que o nosso enfoque está restrito à facilidade que o texto dá para a sua compreensão, deixando a avaliação léxico-sintática por conta do quanto deixa de contribuir para a interpretação textual.

Para informar a banca examinadora dos critérios, fez-se a composição de um texto de instruções que acompanhou todos os lotes de redações destinados aos professores, conforme se segue: 
Critérios de Avaliação de Redações

Os critérios a serem adotados para as avaliações das redações estão abaixo relacionados:

1. A estrutura da frase e as articulações frásicas deverão ser consideradas para o propósito de avaliação;

2. Para a estrutura da frase só devem ser considerados:

os processos que asseguram, a nível sintagmático e oracional, uma ligação significativa entre os elementos lingüísticos que ocorrem na superficie textual. (MATEUS; 1989:137);

3. Para as articulações frásicas só devem ser considerados:

os processos de seqüencialização que exprimem vários tipos de interdependência semântica das frases que ocorrem na superfície textual. (MATEUS: 1989;138);

4. A estrutura temática e a estrutura informacional deverão ser consideradas para o propósito de avaliação; 
5. Constitui a estrutura temática:

o modo como um texto seleciona e vai apresentando os tópicos. (MATEUS: 1989;138);

6. Constitui a estrutura informacional:

o modo como distribui a informação que apresenta. (MATEUS: $1989 ; 138)$

7. Dessa forma, os períodos devem conter:

em princípio, um pensamento complexo, isto é, um pensamento que, relacionando-se embora a outros anteriores e prolongando-se ou ampliando-se em outros seguintes, é, não obstante, suficiente por si mesmo para "formar sentido" de maneira satisfatória. (CAMARA JR; 1986:72)

8. Por fim, o processo de leitura do texto deve dar condições de: 
diferenciar o que constitui o essencial do texto e o que pode ser considerado em um determinado momento - para alguns objetivos concretos - como secundário. (SOLÉ; 1998:116)

9. A nota a ser atribuída deverá estar no intervalo fechado de 0 a 100 pontos, só válida para múltiplos de 5 , ou seja, $\{0 ; 5$; $10 ; \ldots ; 100\}$, sendo que, para cada um dos estágios acima conquistados pelo texto, o avaliador deverá considerar 10 pontos a somar.

10. Os 20 pontos restantes corresponderão à avaliação da facilidade oferecida pela composição do texto para a fluência da leitura. Observa-se aqui a capacidade de progressão seja semântica, seja léxico-sintática.

Para que a pesquisa fosse encaminhada estatisticamente, transformamos a variável contínua nota ${ }^{44}$ numa variável qualitativa ordinal.

Separamos assim as redações em três grupos principais, a saber:

${ }^{44}$ A nota será uma variável praticamente contínua se corresponder à media aritmética das notas atribuídas por cada professor. 
a) Todas as notas atribuídas estão no intervalo fechado de $\mathbf{3 0}$ a $50^{45}$;

b) Todas as notas atribuídas estão no intervalo duplamente aberto de 50 a 80 ;

c) Todas as notas atribuídas estão no intervalo fechado de 80 a $100{ }^{46}$.

Nota-se que a distribuição das redações nesses intervalos se dá acompanhando a distribuição normal, pois $10,35 \%$ encontram-se no primeiro intervalo, $8,12 \%$ no terceiro e as demais no intervalo intermediário $^{47}$.

Como são os grupos extremos os grupos de interesse para a nossa análise estatística, passaremos a nos deter com mais atenção em suas características na parte que se segue.

${ }^{45} \mathrm{O}$ conceito "I" representa esse caso.

${ }_{47}^{46} \mathrm{O}$ conceito "OS" representa esse caso.

${ }^{47}$... a curva normal é unimodal, isto é, possui um só (pico ou) ponto de freqüência máxima; esse ponto, por sua vez, é aquele situado no meio da distribuição (curva), em que a media, a mediana e a moda coincidem.

A partir do topo (central, arredondado), a curva normal "cai" gradualmente até formar as caudas (duas, uma de cada lado), que se estendem de forma indefinida, aproximado-se cada vez mais da linha de base (eixo das abscissas) sem, entretanto, jamais tocá-las (LEVIN, 1987, p.82). 


\subsection{Organização Digital do Corpus}

Toda redação teve atribuída uma referência digital em um

banco de $\operatorname{dados}^{48}$ e passou a ser uma variável identificada por seu registro nesse arquivo.

$O \operatorname{corpo}^{49}$ de cada redação junto de seu respectivo registro foi reunido aos demais produzidos na mesma oportunidade, seguindo as orientações de uma proposta comum, de tal maneira que o conjunto todo estivesse num mesmo arquivo digital. Este foi submetido à avaliação, independentemente, de três professores de português, aqui designados, para fins de registro, como 1, 2, e 3, e, também, por uma pessoa de formação média.

Cada professor devolveu o arquivo com os registros e suas respectivas notas, que, depois de conferidas, foram inseridas no banco de dados.

Após a inserção das notas, os registros foram classificados de tal forma que aqueles, cujas notas, para todos os avaliadores, pertencessem ao intervalo cheio de oito a dez, foram identificados com "OS"

${ }^{48} \mathrm{O}$ banco de dados construído em Access da Microsoft está descrito na parte 4.4 e anexado a esta pesquisa.

49 Cada professor cumpriu a sua tarefa de avaliação a partir do conteúdo da Pasta de Recepção de cada instituição de ensino sem que, porém, pudesse identificá-la nem mesmo tomar ciência dos autores, pois os dados dos cabeçalhos foram retirados. Ao texto da redação sem o cabeçalho de identificação chamamos corpo. 
(plenamente satisfatório) no campo avaliação do respectivo registro no banco de dados.

As notas que, para todos os avaliadores, pertencessem ao intervalo cheio de zero a cinco foram identificadas com "I" (insatisfatório) no campo avaliação do respectivo registro no banco de dados.

Uma forma de consulta foi gerada, no banco de dados, para coletar e separar, em dois grupos, os registros com "OS" e "I", distribuídos em dois relatórios baseados em duas planilhas, nas quais podem ser vistos os números absolutos de ocorrências de cada operador assinalado.

Os dados inseridos nas planilhas acima referidas, em formato de arquivo de Excel, formam o substrato para as fórmulas e macros de aplicação estatística.

É importante notar que, dado um conjunto de redações referentes a uma proposta de escritura, o procedimento metodológico para arquivamento e organização digital consistiu de:

a) digitalizar o seu conteúdo - cabeçalho e corpo da redação - em um único arquivo de extensão doc (natural do aplicativo Word da Microsoft). Vale dizer que se consideram como cabeçalho o nome do aluno, o nome da 
instituição de ensino, o nome do professor, o título (nome definido pela proposta) e as notas a serem atribuídas pelos avaliadores. O arquivo assim obtido denominamos Documento-Documento. $O$ conjunto de todos os arquivos nesse estágio do trabalho foi conservado na Pasta de Recepção;

b) fazer quatro cópias do conteúdo do DocumentoDocumento, retirando dele o cabeçalho de cada corpo de redação, apenas deixando um espaço para a atribuição da nota;

c) remeter as cópias a cada avaliador;

d) receber as cópias e inserir os dados das notas no cabeçalho do Documento-Documento de onde as cópias tiveram origem;

e) transformar o arquivo com as notas inseridas, para cada proposta realizada por turma, em modo texto, por conseguinte, de extensão txt. $O$ arquivo dessa etapa chamamos de Documento-Texto. $O$ conjunto de todos os arquivos nesse estágio do trabalho foi conservado na Pasta de Transformação; 
f) separar todas as redações, uma a uma, do corpo do arquivo de extensão txt. $O$ arquivo de cada redação chamamos de Texto-Texto. $O$ conjunto de todos os arquivos nesse estágio do trabalho foi conservado na Pasta de Trabalho, para a manipulação dos softwares;

g) colocar uma cópia segura (back up) da coleção de redações digitalizadas em Texto-Texto numa Pasta de Arquivo Geral com o Código da Instituição separado por hífen do Código da Proposta;

h) utilizar o conteúdo da Pasta de Trabalho como substrato de trabalho do Stablex, do Etiquetador e das Planilhas de Estatística;

i) colocar os arquivos de Texto-Texto da Pasta de trabalho submetidos ao Etiquetador na Pasta de Redações com Operadores Assinalados;

j) colocar, na Pasta das Macros, as planilhas oriundas do emprego das macros do Stablex sobre os textos contidos na Pasta de Redações com Operadores Assinalados;

k) inserir os dados sobre a contagem de operadores nos respectivos registros do banco de dados; 


\begin{abstract}
l) concentrar, na Pasta de Testes, as planilhas com os dados sobre a freqüência relativa dos operadores dos registros selecionados, segundo o critério de avaliação descrito;
\end{abstract}

m) agregar todas as planilhas na Pasta de Organização.

Dois conjuntos obtidos do universo de redações foram submetidos aos procedimentos desta pesquisa: o conjunto avaliado com 'OS' e o avaliado com ' $I$ '. 


\subsection{O Banco de Dados}

O banco de dados foi construído com o aplicativo Access da Microsoft, baseado em duas tabelas principais: a tabela de propostas ${ }^{50}$ e a tabela de redações.

Essas tabelas são consideradas principais, no planejamento do banco de dados, pois, enquanto a tabela de proposta define o conjunto de todas as redações realizadas sob a tutela de cada proposta, a tabela de redações define a chave primária responsável pela unidade de registro para cada redação.

Isso permite que um mesmo aluno esteja em mais do que um registro, bastando, para isso, que tenha realizado redações para mais do que uma proposta.

O fato de a unidade de registro estar vinculada ao produto e não ao autor reflete bem a preocupação da pesquisa de buscar apenas a relação entre os atributos quantitativos da redação (freqüência relativa de operadores) e os qualitativos da leitura (conceitos de avaliação), desprezando completamente a identidade do autor, da instituição de 
ensino e do professor responsável pela proposta, que constam do banco de dados por questão de organização burocrática.

Aliás, os autores das redações estão registrados na tabela de alunos, e os professores responsáveis, na tabela de professores, para facilitar o preenchimento do formulário de redações, que usufrui do relacionamento criado entre essas tabelas e as duas principais.

A preferência à inserção manual em um banco de dados frente a um programa que colhesse os textos e fizesse todas as operações discriminadas nos procedimentos apresenta as vantagens de mostrar as etapas passo a passo e de permitir a conferência do processo esperado para cada uma delas.

Na página seguinte está esquematizada a entrada dos dados do multidocumento (Texto-Texto) pela intervenção manual no formulário do banco de dados e 0 armazenamento interno das diferentes informações nas tabelas relacionadas.

Após, os relacionamentos entre as tabelas estão explicitados pela interface do $\underline{\text { Access. }}$.

Um amálgama dos formulários está a disposição no Anexo 1 com dados de teste para mostrar a intimidade das tabelas pelas interfaces de 
entrada de dados. Ali estão os formulários de alunos, propostas, professores, redações. 


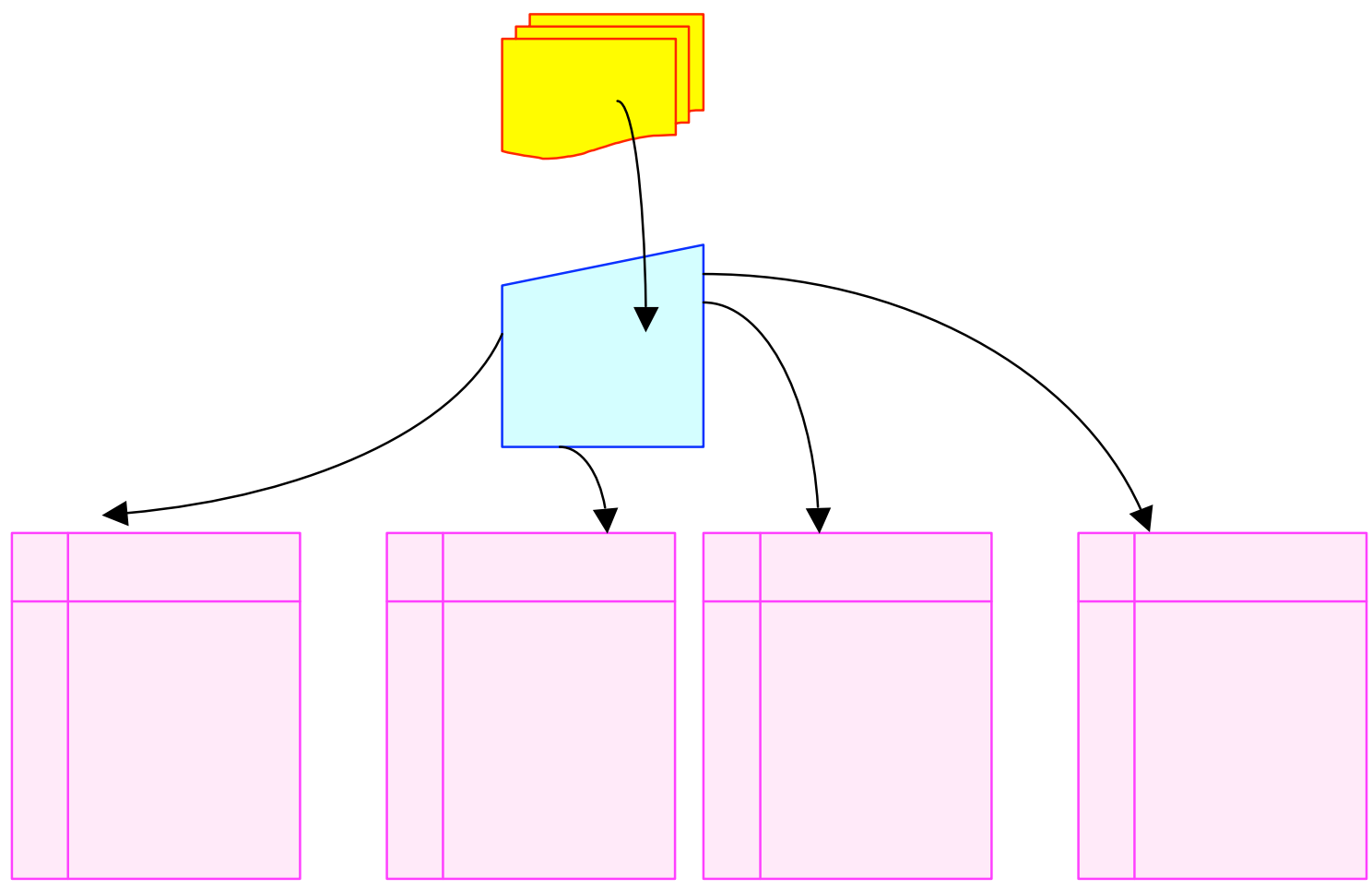

Rellacionamentos AE REDACOES

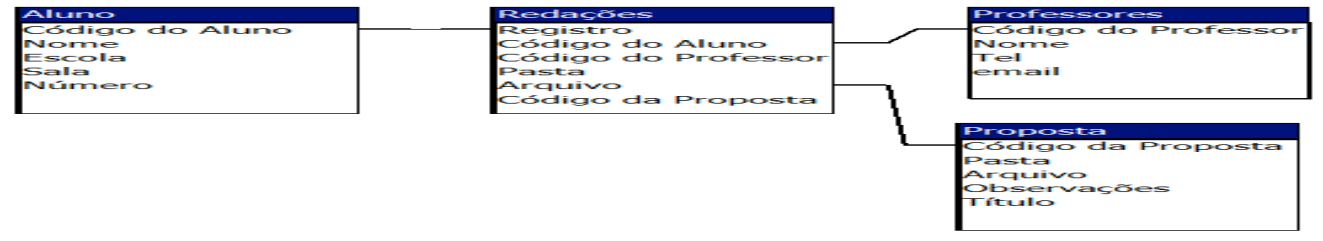




\subsection{Os Relatórios e As Planilhas}

Com base nos procedimentos descritos, constituiu-se um conjunto de dados, relativo à variável avaliação, biunivocamente relacionado ao corpus lingüístico, no qual alguns operadores, previamente selecionados, estão etiquetados.

A razão do resultado da contagem dos operadores encontrados no corpo de cada redação pelo respectivo número total de lexias fornece a freqüiência relativa de operadores da variável em questão.

O procedimento que se segue para a manipulação das frequiências relativas de operadores e das notas de cada variável tem início através da seleção das variáveis que apresentam correlação acima de 0,85.

Somente as variáveis selecionadas terão a avaliação da dependência entre as notas e as freqüências relativas. 


\subsection{O Resultado da Correlação}

Ao separarem-se as redações em dois conjuntos, percebeu-se que não haveria uma quantidade suficiente para que se realizasse uma filtragem anterior aos testes de hipótese com as melhores redações.

Distribuídas em várias propostas diferentes, não fazia sentido que fizéssemos uma filtragem para ver o quanto estavam centradas em torno do tema da proposta.

Recolhemos, então, um conjunto de redações ruins pertencentes ao Banco de Dados e fizemos o teste de correlação. Depois avaliamos se haveria alguma vantagem em se filtrarem as piores para obtermos um resultado homogêneo, quanto à variável freqüência relativa. Conforme se nota no Anexo digital, não é possível sustentar esta afirmação.

Concluímos, portanto, que, para uma amostra tão reduzida, não faz sentido o uso do Stablex para auxiliar na filtragem das redações de interesse. 


\section{Análise dos Resultados}

Conforme já vimos, descartado o uso do Stablex, foram selecionadas as redações apenas segundo o conceito atribuído pelos professores e classificadas em dois conjuntos - um referente às melhores e outro às piores redações.

Após a identificação dos operadores já previamente definidos no corpo de cada texto, foi feita a contagem da ocorrência dos operadores etiquetados, bem como do total de palavras que constavam no texto sem se levar em conta os títulos das redações.

Para cada redação foi obtida uma freqüência relativa como resultado da razão entre o número de operadores detectados pelo número total de palavras.

Os resultados obtidos podem ser vistos nas próximas tabelas, nas quais estão relacionados os registros das redações (conforme estão no banco de dados) e as respectivas freqüências relativas (da coluna denominada op/pal): 
Registro op/pal

180,11956522

31

370,07142857

480,11594203

490,11666667

580,09917355

$66 \quad 0,1119403$

680,08724832

$71 \quad 0,09375$

730,12025316

750,11510791

800,10267857

81

0,09

850,11428571

1660,11397059

1890,11038961

$270 \quad 0,1147541$

2880,11656442

2890,11949686

2930,10687023

2970,11214953

3020,11290323

540,06930693

$97 \quad 0,088$

990,12972973

$102 \quad 0,08125$

1060,12621359

1070,10204082

1090,09047619

1290,18987342

1340,09090909

1380,17391304
1480,13513514

1550,12608696

1560,07964602

$159 \quad 0,1015625$

1600,10588235

$163 \quad 0,125$

1640,12077295

1760,13432836

1770,08247423

1840,09933775

2020,12380952

2130,07042254

2270,08974359

2280,08602151

2660,16666667

2710,12727273

2720,09489051

2730,14285714

2740,08974359

2750,11206897

$276 \quad 0,08$

2800,13740458

2820,10185185

3130,09782609

3140,11612903

3160,11965812

3180,13513514

$319 \quad 0,078125$

3200,11666667

3300,10273973

3380,09638554

3390,11538462

$340 \quad 0,0969697$ 
As redações, cujos registros estão destacadas em azul, correspondem àquelas de melhor conceito, segundo o que foi apurado pelo relatório fornecido pelo banco de dados.

Separadas das demais podemos calcular a mediana, os quartis e a média das freqüiências relativas com a variância, conforme observamos abaixo:

\begin{tabular}{|c|c|c|}
\hline & op/pal & \\
\hline Discrepante & 0,07142857 & \\
\hline & 0,08724832 & \\
\hline & 0,09 & \\
\hline & 0,09375 & \\
\hline & 0,09917355 & \\
\hline & 0,1 & \\
\hline & 0,10267857 & \\
\hline & 0,10687023 & \\
\hline & 0,11038961 & \\
\hline & 0,1119403 & \\
\hline & 0,11214953 & \\
\hline & 0,11290323 & \\
\hline & 0,11397059 & \\
\hline & 0,11428571 & \\
\hline & 0,1147541 & \\
\hline & 0,11510791 & \\
\hline & 0,11594203 & \\
\hline & 0,11656442 & \\
\hline & 0,11666667 & \\
\hline & 0,11949686 & \\
\hline & 0,11956522 & Amplitude: Diferença entre \\
\hline & 0,12025316 & os valores máximo e \\
\hline Média & 0,1075063 & mínimo dessa amostra ; \\
\hline Amplitude & 0,04882459 & Md: Mediana; \\
\hline Md & 0,11252638 & Q1: Primeiro Quartil; \\
\hline$n$ & 22 & Q2: Segundo Quartil; \\
\hline Q1 & 0,1 & |(Média - Md)| : Valor \\
\hline Q3 & 0,11594203 & absoluto da diferença entre \\
\hline $\mid($ Média-Md) $\mid=$ & 0,00502008 & Média e Mediana desses \\
\hline |(Média-Md)|/Média & 4,66956841 & \\
\hline
\end{tabular}


Uma redação apresenta-se com a freqüência relativa discrepante quando comparada tanto com a média quanto com a mediana e, para melhor visualização, foi assinalada em vermelho.

Trata-se de uma redação, conforme se vê abaixo, com poucos operadores, porém considerada bastante coerente pela banca examinadora.

\section{7}

A leitura deveria estar incorporada às ações diárias de qualquer pessoa. Não deveria estar restrita a pedidos de professores nas escolas, como método de avaliação. Lendo se conquista horizontes.

A leitura precisa ser apresentada já na infância, aos pequenos, como fonte de diversão. Não faltam opções nas livrarias de material para despertar o interesse de tão jovens leitores. Talvez o que falta seja o hábito de tornar a leitura uma rotina.

As vantagens de quem está habituado à leitura são inúmeras. Lendo se viaja por lugares desconhecidos, vivencia-se outras culturas, além do que, qualquer aprendizado ase torna mais fácil.

Uma vez que a alimentação diária cuida do corpo, nada nos impede de incorporara a leitura às nossas vidas para cuidarmos melhor de nossa mente e alma.

Conforme já mostramos na página 56, Widdowson afirma que é

possível construir textos desprovidos de marcas de coesão, mas dotados de coerência, em virtude de o produtor fornecer os índices necessários para realizar a comunicação, pois conta com o que o interlocutor pode deduzir do seu discurso. 
De acordo com o que prevíamos, encontramos um texto com avaliação positiva ainda que tenha uma freqüência relativa de operadores discrepante se comparada à média encontrada na amostra.

Considerando que essa redação equivale, aproximadamente, a 4,54\% do total do conjunto das boas redações, notamos que os resultados ratificam a nossa hipótese de trabalho, ou seja, confirmam que a afirmação de Widdowson, apesar de verdadeira, corresponde a um conjunto de eventos com baixa probabilidade de ocorrência no universo da construção textual escrita.

Podemos notar, também, que essa redação descreve fatos constatados pela vivência do autor, que, embasado em um elenco de premissas, chega ao final com uma proposição que mais as parafraseia do que conclui.

Trata-se, pois, de um texto que, a seu modo, encontra-se no limite do que se considera uma dissertação, pois quase não argumenta.

De fato, observando um mesmo conteúdo submetido à conformação de gêneros distintos, notamos que podem ser compostos bons textos com mais ou com menos elementos de coesão de acordo com o gênero seguido. 
Para essa redação, portanto, afirmamos que houve uma estrutura econômica no uso de elementos de coesão, por estar alicerçada em premissas bem conhecidas pelo leitor ao qual o autor imaginava destinar o texto e, também, pelo fato de que não se considerou necessário responder a possíveis contestações, o que tornou a argumentação uma seqüência de afirmações coerentes entre si, mas que ignoravam a presença de um interlocutor com uma opinião divergente.

O segundo conjunto, formado pelas redações para as quais a banca examinadora atribuiu os piores conceitos, tem a média das freqüências relativas, visivelmente, próxima daquela observada no conjunto anterior.

A média do conjunto anterior é, aproximadamente, $\mathbf{0 , 1 0 7 5 0 6 3 ,}$ enquanto que a do segundo conjunto é, aproximadamente, 0,11045842 . A diferença entre as duas médias vale 0,0039 , que, frente a uma ordem de grandeza proporcional a 0,109 , representa apenas, aproximadamente, $3,26 \%$ dessa grandeza.

As médias desses dois conjuntos podem ser consideradas ainda mais próximas, se considerarmos a amplitude dos valores das freqüências relativas. No primeiro conjunto essa amplitude vale, aproximadamente, 0,042, enquanto que no segundo vale, aproximadamente, 0,121 . 


\section{A seguir estão as freqüências relativas de cada redação do}

segundo conjunto.

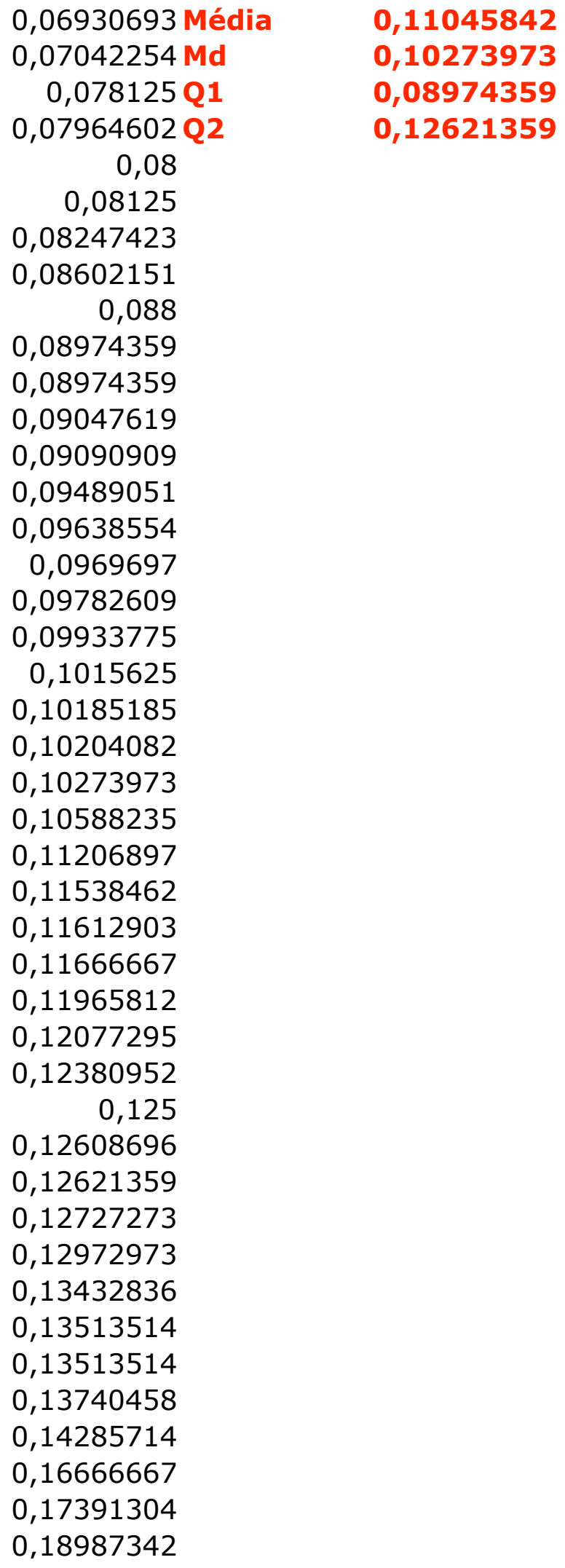


Usando a variância das amostras, observamos que as médias desses dois conjuntos podem ser consideradas iguais, o que corresponde à aceitação da hipótese nula $\left(\mu_{1}=\mu_{2}\right)^{51}$.

Isso significa que encontramos uma variável de valor constante para os dois conjuntos. Resta-nos, então, verificar se essa variável permanece constante para um conjunto de redações recolhidas aleatoriamente do banco de dados.

Selecionamos, aleatoriamente, um conjunto de redações para observar o comportamento da média das freqüências relativas dos operadores.

$O$ conjunto de 8 redações, conforme pode ser apreciado no Anexo 2, tem as frequiências relativas das redações apresentadas na tabela que segue.

\begin{tabular}{ccccc} 
Redação & \multicolumn{2}{c}{ N Operadores N Palavras } & \multicolumn{2}{c}{ Freqüências Relativas } \\
1 & 16 & 141 & 0,11347518 \\
2 & 16 & 113 & 0,14159292 \\
3 & 11 & 123 & 0,08943089 \\
4 & 16 & 164 & 0,09756098 \\
5 & 20 & 146 & 0,1369863 \\
6 & 16 & 134 & 0,11940299 \\
7 & 12 & 135 & 0,08888889 \\
8 & 7 & 86 & 0,08139535 \\
& Média & & 0,10859169
\end{tabular}

${ }^{51}$ Os cálculos e as planilhas estão no Anexo 4 (digital). 
A comparação da média do grupo das 8 redações, 0,10859169 , com aquela média obtida do conjunto união dos dois conjuntos que havíamos formado (das melhores e das piores redações) ${ }^{52}, \mathbf{0 , 1 0 7 9 6 7 4 ,}$ permite, também, a aceitação da hipótese nula.

O conjunto formado pelas 8 redações não apenas serve para mostrar que a média das freqüiências relativas é uma invariante, também faz notar que o seu valor é obtido em amostras relativamente pequenas.

Quando um estimador converge para o valor esperado de uma variável de interesse da população, referimo-nos a ele como estimador consistente. Assim, o estimador da média das freqüências é consistente.

Se, por um lado, as médias das freqüências relativas de operadores não permitem distinguir os conjuntos de redações, por outro, o posicionamento de cada um dos valores assumidos por essa variável em relação à média é muito distinto.

A dispersão das freqüências da amostra das melhores redações é muito inferior àquela da amostra das redações consideradas ruins.

No intervalo fechado de valores para a média entre 0,099 e 0,121, encontram-se, aproximadamente, $81,8 \%$ das redações boas e apenas, aproximadamente, $27,9 \%$ das redações ruins, conforme se vê no box-plot.

${ }^{52}$ Os cálculos e as planilhas estão no anexo 4. 


\section{Box-plot}

Distribuição das freqüências relativas no conjunto das piores redações.

Distribuição das frequiências relativas no conjunto das melhores redações.

$\square$ Distribuição das frequiências relativas no conjunto formado pela união dos dois conjuntos anteriores.

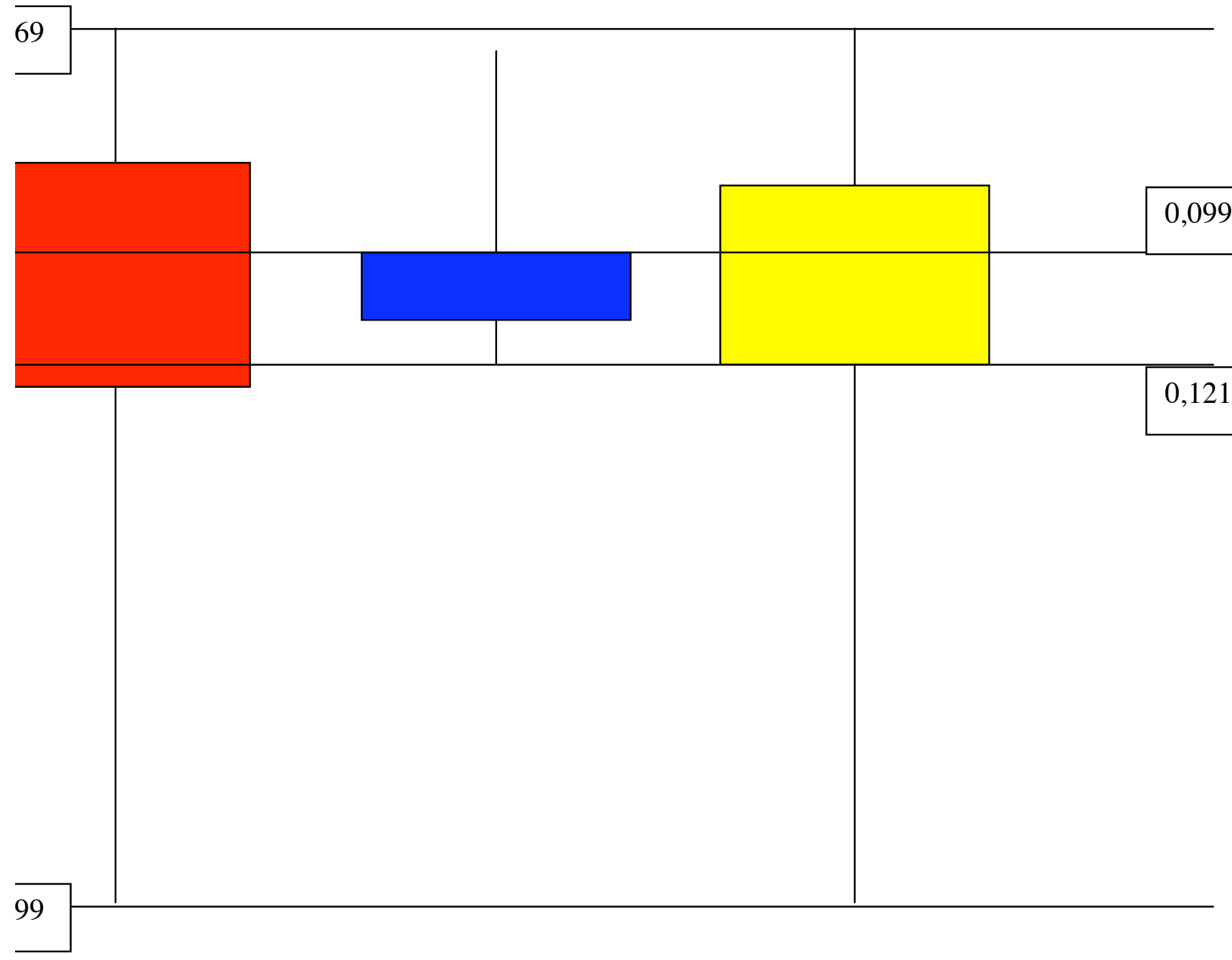


Outra maneira de ilustrar a diferença de dispersão dos valores observada nos dois conjuntos é através do gráfico de barras, que mostra a distribuição de todas as freqüências relativas dos operadores, relacionando-as às respectivas redações.

É possível notar, tomando o gráfico do primeiro conjunto como ponto de partida, que, a cada subconjunto de aproximadamente 8 redações subseqüentes, a média mantém o comportamento já descrito.

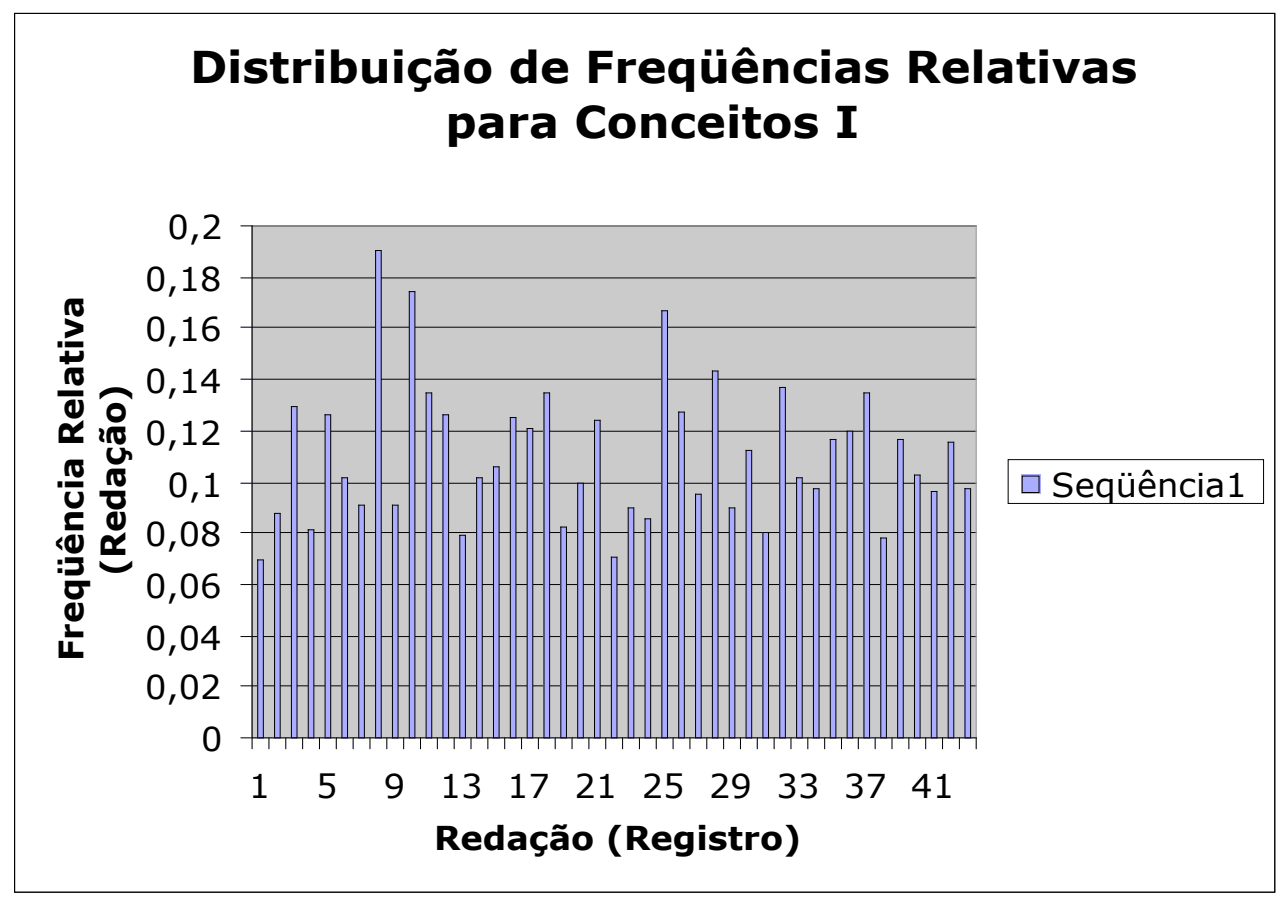

Se confrontarmos o gráfico do primeiro grupo com o do segundo, sem a presença da redação discrepante, podemos perceber que, neste último, a altura das barras é mais homogênea, ou seja, os valores unitários se distanciam pouco da média observada no conjunto. 
Distribuição de Freqüências Relativas para Conceito OS

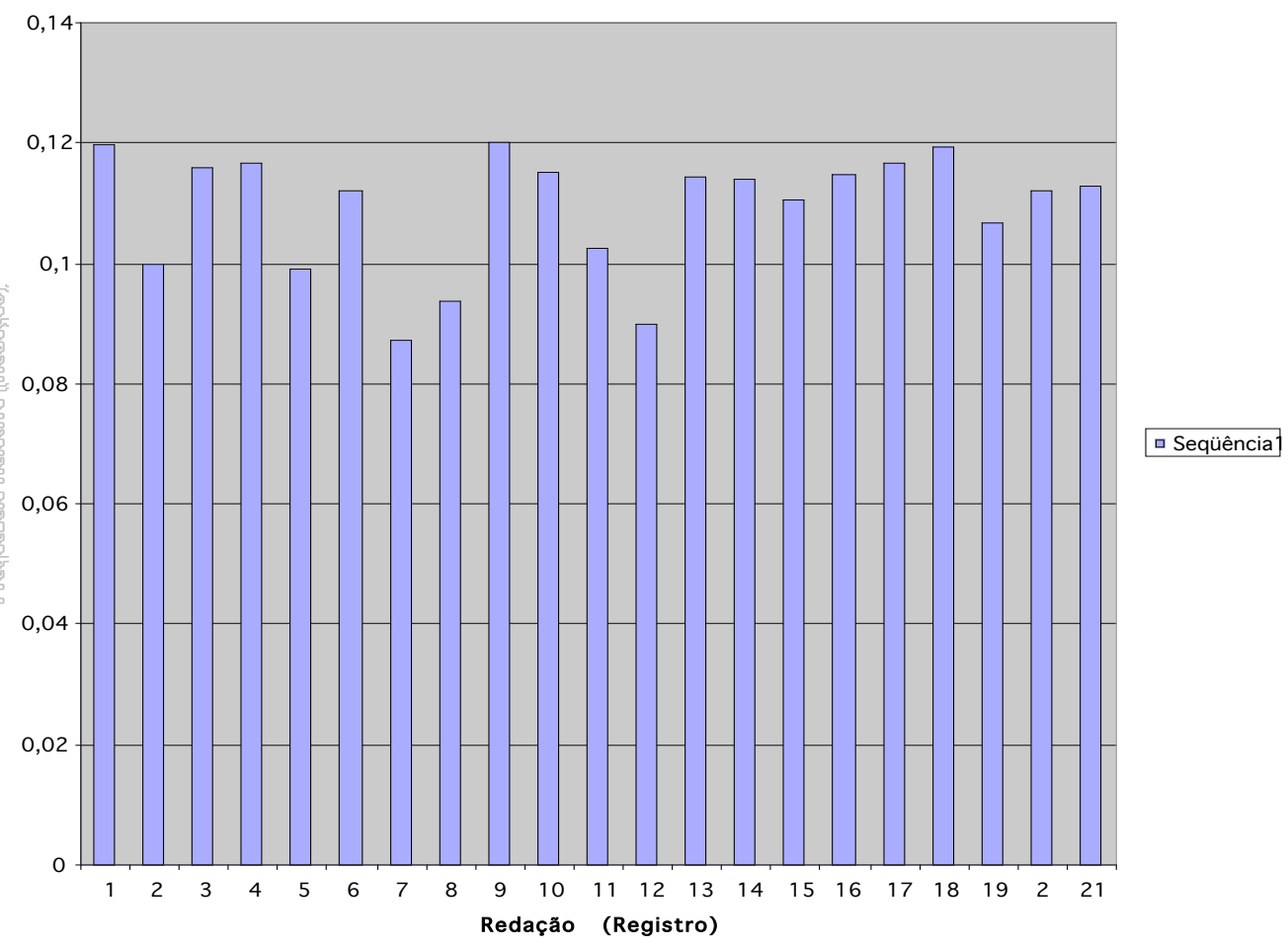

Duas informações podem ser extraídas, portanto, dos dados, a saber:

a) existe uma média observada das freqüências relativas de operadores que persiste em quaisquer dos conjuntos estudados;

b) o comportamento de posição das freqüências relativas de operadores de cada redação frente à média é muito distinto quando comparamos o conjunto das redações boas com o das ruins. 
Interessa-nos verificar se o posicionamento pode ser considerado, estatisticamente, dependente da variável e do conceito atribuído. Para tanto, vamos considerar a faixa definida pelo intervalo fechado $[0,099$; 0,121] para classificarmos as redações, de tal forma que tenhamos um grupo de redações dentro e outro fora desse intervalo.

Uma tabela que apresenta a associação das duas variáveis pode ser a que vemos a seguir.

\begin{tabular}{|l|l|l|l|}
\hline QualidadelPosição & Dentro & Fora & Total \\
\hline Boa & 18 & 4 & 22 \\
\hline Ruim & 12 & 31 & 43 \\
\hline Total & 30 & 35 & 65 \\
\hline
\end{tabular}

Podemos fazer um teste de hipótese sobre a dependência das variáveis, considerando, para tal fim, a tabela acima de um ponto de vista diferente.

\begin{tabular}{|l|l|l|}
\hline CONJUNTO & AMOSTRA & $\begin{array}{l}\text { PROPORÇÃO } \\
\text { DENTRO/TODAS }\end{array}$ \\
\hline BOA & & 0,818 \\
\hline RUIM & 22 & 0,279 \\
\hline
\end{tabular}


Realizamos, então, um teste de hipóteses para amostras diferentes com variâncias desconhecidas e diferentes para investigar se o fato de estar dentro ou não da faixa é afetado pela qualidade das redações.

O resultado dos procedimentos estatísticos, conforme se vê no Anexo 4, pode ser, assim, resumido:

a ) as proporções são diferentes para um nível de significância de 5\%;

b) a mesma afirmação é válida se quisermos colocar a questão como se a avaliação fosse afetada pelo fato de a redação estar dentro ou fora do intervalo acima definido.

É importante dizer que o intervalo que usamos para afirmar que o texto estava dentro, foi estabelecido de forma arbitrária. Ele foi criado, tendo em vista a maximização da diferença entre as proporções. Entretanto, pode-se notar que corresponde à média das freqüências relativas do conjunto de todas as redações subtraída de $10 \%$ do seu valor para o limite inferior do intervalo e acrescida de $10 \%$ de seu valor para 0 limite superior.

A explicação que damos ao fato de existir uma média persistente e de o grupo pior avaliado apresentar uma dispersão das suas freqüências relativas muito maior do que a do melhor avaliado é que existe um padrão 
subentendido por cada indivíduo para a distribuição dos operadores na constituição de um texto. Aqueles que apresentam maior destreza aproximam-se mais dele do que os demais, porém todos perseguem o mesmo objetivo. 
Conclusão 


\section{Conclusão}

A constatação de padrões na estrutura textual é o primeiro passo para que se possa fazer a distinção entre um aglomerado de palavras e um texto, bem como entre textos, avaliando-os, conforme as condições que apresentam para propiciar a leitura.

Esse procedimento de leitura, capaz de servir de baliza, consideramos se tratar de um processo realizado por um leitor ideal para o texto considerado, ou seja, aquele que o autor vislumbrava como destinatário do texto produzido.

Com relação ao padrão estrutural que buscávamos, concluímos que existe uma tendência acentuada de que o valor esperado da média das freqüências relativas de operadores seja uma constante válida para qualquer conjunto de textos dissertativos.

A constante mencionada pode ser estimada pelo intervalo de valores a que esteve restrita a média amostral das freqüências relativas, que, para todos os experimentos, esteve entre 0,110 e 0,107.

Sabemos que o valor da média amostral de um parâmetro tende para o valor do seu valor esperado na população, quanto maior for o tamanho da amostra. 
Poder-se-ia afirmar, portanto, que as amostras não foram suficientemente grandes para que atribuíssemos a propriedade da média ao valor esperado. Entretanto, a convergência para o valor médio é obtida já para grupos de apenas 8 redações escolhidas aleatoriamente, como pode ser visto no exemplo do anexo 3.

Assim, 65 redações apresentam, para esse parâmetro (a média das freqüências relativas), o mesmo comportamento que 43 dessas 65 , ou 11 dessas 65, ou, até, 8 redações recolhidas aleatoriamente do banco de dados.

O fato descrito não está sujeito a variações mesmo quando se é empregado um fator de classificação baseado na qualidade textual. Notese que a média das melhores redações do banco de dados é 0,1075 e a das piores é 0,1104 , que corresponde a uma amplitude de 0,0039 frente a uma ordem de grandeza proporcional a 0,109 , o que representa apenas, aproximadamente, $3,26 \%$ dessa grandeza.

Ainda que quaisquer amostras aqui observadas possuíssem a tendência relatada, a dispersão das freqüências da amostra das melhores redações é muito inferior àquela da amostra das redações consideradas ruins. 
De tal forma isso ocorre que, dentro do intervalo fechado de valores para a média entre 0,099 e 0,121 , encontram-se, aproximadamente, $81,8 \%$ das redações boas e apenas, aproximadamente, $27,9 \%$ das redações ruins.

Por conseguinte, é natural pressupor que seja possível, por meio dessa característica apontada, uma averiguação computacional prévia capaz de distinguir se o objeto de trabalho é texto de um gênero específico e não uma coleção de palavras, ou de orações, ou ainda de parágrafos.

É importante ressaltar que os resultados sugerem a existência da dependência entre a freqüência relativa de operadores e a tessitura de textos dissertativos, mesmo quando os operadores selecionados não se apresentam corretamente empregados, inclusive quando não seguem as operações lógicas previstas pela sintaxe.

Em virtude de ser uma propriedade estatística a constatação da dependência entre a freqüência relativa de operadores e o resultado da avaliação atribuído ao texto, não se pode deduzir que exista uma relação determinística essas variáveis. De fato, é possível que se procurem meios de se apurar uma seleção de operadores e de se encontrar uma função que manipule as quantidades de suas ocorrências de tal forma que se otimize a relação de dependência apontada. 
Isso, dito de outra forma, significa que, como os conceitos foram atribuídos tendo como critérios que valoravam, prioritariamente, a coesão e a coerência, os resultados desta pesquisa sugerem ser possível construir um algoritmo que avalie, estatisticamente, tais propriedades textuais a partir da freqüência relativa dos operadores; portanto, sem ter de recorrer ao conjunto lexical empregado nem destrinchar a sintaxe em busca da análise semântica.

O Método de André Camlong, em específico a correlação obtida pelo Stablex, tem, para esta pesquisa, o objetivo de escolher os textos que respeitem a temática proposta, evitando que possam ser avaliados, quanto à tessitura, textos que tangenciem o tema.

É importante ressaltar que nada, neste trabalho, permite afirmar que a aplicação do Método é inválida para o que se pretendia, porém notou-se que, para que se fazer uma avaliação do procedimento utilizado, como filtro e catalisador do processo, será necessário reunir um grupo maior de redações com o mesmo conceito e a mesma proposta temática.

O procedimento de inferência estatística visa, de primeiro, a constatar as propriedades das medidas de posição e de dispersão das freqüências relativas dos operadores num conjunto de redações 
dissertativas e, em segundo momento, a observar a dependência entre essas propriedades e as notas atribuídas pela banca examinadora.

Podemos concluir, partindo dos objetivos perseguidos por esta pesquisa, que:

a) a modelagem matemática aqui desenvolvida, baseada na coleta seletiva de ligantes - operadores -, é capaz de fornecer resultados que mostram a existência de dependência entre a freqüência relativa desses elementos num texto escrito e a avaliação do grau de coesão e coerência nele observado por um profissional no papel de leitor;

b) existe uma faixa-padrão de distribuição das freqüências relativas de operadores encontrada num conjunto de redações dissertativas, fora da qual o interlocutor considerará prejudicada a sua tessitura.

Propomos, como explicação para os fatos observados, que:

a) o texto não é produzido por um processo linear de escolhas, de tal sorte que o próximo constituinte a ser inserido no enunciado não está sujeito apenas à consideração do 
enunciador, baseada somente na parte já realizada do texto;

b) os operadores também têm o papel de sugerir ao leitor a existência de tessitura textual e servem de marcas observáveis durante a leitura;

c) o texto é construído por blocos capazes de respeitar o intuito primeiro do enunciador quanto às características semânticas pretendidas para o texto. A existência, portanto, da constância da média das freqüências relativas dos operadores é reflexo de um papel que os operadores executam para pontuar a distribuição a ser realizada desses blocos, facilitando, para o enunciatário, o processo de leitura.

d) as marcas servem como pistas do gênero do texto e visam, também, a facilitar o leitor a encontrar a estratégia mais adequada para a sua leitura.

Em suma, entendemos que a consistência da média das freqüências relativas de operadores sugere que, tanto o produtor, quanto o leitor do texto escrito têm um gabarito virtual para a distribuição de 
operadores a ser seguido durante o processo de escritura de textos em cada gênero.

Acreditamos que a atual pesquisa incide luz sobre paisagens a serem exploradas. Podemos citar como focos de interesse decorrentes desta pesquisa:

- Através do uso do Método de Camlong

a) a partir da aplicação do teste de correlação, observar, nos resultados já obtidos, o efeito de separação e retirada de redações de baixo valor de correlação de um conjunto numeroso de redações de mesma proposta temática;

b) a partir das Tabelas de Valores Lexicais (TVLs), verificar se existe relação entre a distribuição das freqüências relativas e o tipo de vocabulário, conforme a classificação em preferencial, básico e diferencial.

- Através da ampliação do procedimento corrente

a ) a confirmação da dependência entre a média das freqüências relativas de operadores e o gênero praticado, através da ampliação da investigação a outros tipos de gêneros textuais; 
b) a busca de uma função capaz de otimizar a dependência aqui observada;

c) a estimativa matemática do significado da contribuição da análise semântica empreendida pelo pesquisador, quando do procedimento de correção das seleções inadequadas de operadores produzidas por um etiquetador computacional usado para essa finalidade;

d) a busca de fatores que minimizem a contribuição referida acima, visando a transformar toda a operação descrita neste trabalho num procedimento computacionalmente confiável. 
Bibliografia 


\section{Bibliografia}

ALtMAn, Maria Cristina Fernandes. Estruturas de Léxico: Competência, Desempenho e Procedimentos Lingüístico-Pedagógicos de Ensino para Alunos da Quinta Série do Primeiro Grau. São Paulo, 1986. 419 p. Dissertação (Mestrado em Semiótica e Lingüística Geral)- Departamento de Lingüística da Faculdade de Filosofia Letras e Ciências Humanas da Universidade de São Paulo.

A Pesquisa Lingüística no Brasil (1968-1988). São Paulo: Humanitas/FFLCH/USP, 1998.

ARAÚJO, Ubirajara Inácio de. Tessitura Textual: Coesão e Coerência como Fatores de Textualidade. São Paulo: Editora Humanitas, 2002.

BAKHTIN, Mikhail. Estética da Criação Verbal. São Paulo: Editora Martins Fontes, 2000.

BARROS, Diana Luz Pessoa de. Teoria do discurso: Fundamentos Semióticos. São Paulo: Editora Atual. 1988.

BARROS, Nereida Valêncio. Estudo do Emprego e Funções dos Operadores Argumentativos 'Mas' e 'Embora' em Textos Escolares. Pelotas, 2003. Dissertação (Mestrado em Letras). Universidade Católica de Pelotas. 
BASTOS, Lúcia Kopschitz. Coesão e Coerência em Narrativas Escolares. São Paulo: Martins Fontes, 2001.

BLIKSTEIN, Izidoro. Técnicas de Comunicação Escrita. São Paulo: Ática. 1985. (Série Princípios, 12).

BRAIT, Beth. Ironia em Perspectiva Polifônica. Campinas: Editora da UNICAMP. 1996.

BUSSAB, Wilton de O.; MORETTIN, Pedro A.. Estatística Básica. São Paulo:Editora Saraiva.2002.

CAMARA JR, Joaquim Mattoso. Manual de Expressão Oral e Escrita. Rio de Janeiro: Vozes. 1986.

CAMlong, André. Méthode d'Analyse Lexicale Textuelle et Discursive. Paris: Ophrys. 1996.

CHARMEUX, Eveline. Aprender a Ler: Vencendo o Fracasso. Trad. Maria José do Amaral Ferreira. São Paulo: Cortez, 2000. Título original: Apprendre à lire: èchec à l'échec. 
CHAROLleS, M. Introduction aux Problèmes de la Coherence des Textes. Langue Française. Paris: Larousse. 1978.

DUCROT, Oswald. Provar e Dizer. São Paulo: Editora Global. 1981. Les Mots du Discours. Paris: Minuit, 1980.

Les Modificateurs déréalisants. In: Journal of Pragmatics, 24 1/2 145-66. 1995.

ECO, Umberto. Os Limites da Interpretação. São Paulo: Editora Perspectiva. 2000.

EHLICH, K. .Anaphora and deixis: same, similar, or different?. In: JARVELLA, R. J. \& W. KLEIN (eds.). Speech, place, and action. Chichester: John Willey \& Sons. 1981.

FERRERO, Emilia; TEBEROSKY, Ana. Psicogênese da Língua Escrita. 4. ed. Trad. Diana Myriam Lichtenstein, Liana di Marco e Mário Corso. Porto Alegre: Artes Médicas. 1991.

GARCIA, Othon Moacyr. Comunicação em Prosa Moderna. Aprenda a Escrever, Aprendendo a Pensar. 2. ed. Rio de Janeiro: Fundação Getúlio Vargas. 1972.

GUIMARÃES, Elisa. A Articulação do Texto. São Paulo: Editora Ática. 2001 
GROSS, Maurice. Modelos Matemáticos em Lingüística. Trad. Alberto Oliva Rio de Janeiro. Zahar. 1976.

HALLIDAY, M. A. K.. Estrutura e Função da Linguagem. In: LYONS, John. Novos Horizontes em Lingüística. São Paulo: 1976.

HALLIDAY, M. A. K.; HASSAN, R. Cohesion in English. Londres: Longman, 1976.

HOFFMANN, Jussara Maria Lerch. Avaliação: mito e desafio: uma perspectiva construtivista. 36. ed. Porto Alegre: Mediação, 2006.

KOCH, Ingedore Villaça. A Inter-ação pela Lingüagem. São Paulo: Contexto. 1992. O Texto e a Construção dos Sentidos. São Paulo: Editora Contexto. 2000.

KOCH, Ingedore Villaça e TRAVAgLIA, Luiz Carlos. A Coerência Textual. São Paulo: Contexto. 2000.

LEVIN, Jack. Estatística Aplicada a Ciências Humanas. 2. ed. Trad. Sérgio Francisco Costa. São Paulo: Harbra, 1987.

MAINGUENAU, Dominique. Novas Tendências em Análise do Discurso. Campinas: Editora da Unicamp. 1997. 
MACHADO, Irene A. "Texto \& Gêneros: Fronteiras". In: Espaços da Lingüagem na Educação. São Paulo: Editora Humanitas. 1999.

MAgalhãeS, Marcos Nascimento; LIMA, Antonio Carlos Pedroso de Lima. Noções de Probabilidade e Estatística. São Paulo: Edusp. 2004.

MARCUSCHI, Luiz A. Lingüística do Texto: O que é e como se faz. Recife: UFPE-Série Debates 1, 1983.

- Marcadores Conversasionais do Português Brasileiro: Formas, Posições e Funções. Campinas: Editora da UNICAMP. 1989. p. 281-321.

MATEUS, Maria Helena Mira; BRITO, Ana Maria; DUARTE, Inês Silva; FARIA, Isabel Hub. Gramática da Língua Portuguesa. Lisboa: Caminho.1989.

MICROSOFT Office 2000 Profissional, [S.l.]: Microsoft Corporation, 2000. Conjunto de Programas. CD-ROM.

PERRENOUD, Philippe. Avaliação: Da Excelência à Regulação das Aprendizagens. Entre Duas Lógicas. Trad. Patrícia Chittoni Alessandrini. Porto Alegre: Artmed, 1999. 
RINO, Maria Lúcia. Modelagem do Discurso para o Tratamento da Concisão e Preservação da Idéia Central na Geração de Textos . São Carlos, 1996. 362 p. Tese Departamento de Informática do Instituto de Física de São Carlos da Universidade de São Paulo.

RUSSEL, Bertrand. A Perspectiva Científica. Trad. José Severo de Camargo Pereira. 4. ed. São Paulo: Companhia Editora Nacional, 1977. Título original: The Scientific Outlook.

SMITH, Frank. "The Relation Between Spoken and Written Language", in: Lenneberg, E. y Lenneberg, El. (Eds.) Foundations of language development (vol2). Nova York e Londres:UNESCO PRESS,1975.

SINCLAIR, J. McH. Corpus, Concordance, Collocation. Oxford: Oxford University Press, 1991.

SOLÉ, Isabel. Estratégias de Leitura. Trad. Cláudia Schilling. 6. ed. Porto Alegre: Artmed. 1998. Título original: Estrategias de Lectura.

STABLEX. Toulouse: 2003. Conjunto de Programas: Stablex e Macro.xls. CD-ROM.

THEREZO, G. P.. Critérios para a Avaliação de Redações. LETRAS, 11:84-128, dez. Campinas, 1992. 
Como Corrigir Redação. Campinas: Alinea, 1997.

TERZI, Sylvia Bueno. A Construção da Leitura. São Paulo. 3. ed. Campinas: Editora Pontes, 2002.

VAL, M. G. C.. Redação e Textualidade. São Paulo: Martins Fontes. 1991.

VAN DIJK, Teun. Texto Y Contexto: Semántica y Pragmática del Discurso. Trad. Juan Domingo Moyano. 6. ed. Madri: Cátedra, 1998. Título original: Text and Context.

WIDDOWSON, H. G.. Une Approche Communicative de L'enseignement des Langues. Paris: Haitier. 1981.

WOODS, Anthony; FLETCHER, Paul; HUGHES, Arthur. Statistics in Language Studies. Cambridge University Press. 2000.

ZAPPAROLI, Zilda Maria; CAMLONG, André. Do Léxico ao Discurso pela Informática. São Paulo: EDUSP/FAPESP. 2002. 
ANEXOS 
ANEXO 1 


\title{
REDAÇÕES DE CONCEITO OS
}

\author{
(Melhores)
}

\section{8}

Quem nunca ao estar lendo algo, seja no colégio no trabalho ou em casa e fez a seguinte pergunta. Qual a importância da leitura?

Tentarei expor, sucintamente o seu valor.

Ler traz conhecimento e informações relacionadas com diferentes áreas do conhecimento, ou seja, qualquer que sejam suas referências há livros, revistas, panfletos, jornais, relacionados com ela.

A leitura também dá asas para a imaginação, desenvolvendo assim a criatividade do leitor.

Mesmo para quem quer apenas relaxar e "esfriar a cabeça" existe algo para ler como gibis, palavras cruzadas e livros de ajuda.

\section{1}

Ao ler, o leitor fica informado sobre acontecimentos reais, fictícios, recentes ou antigos. Essas informações são importantes para enriquecer o seu conhecimento.

A leitura é capaz de desenvolver a criatividade imaginária do leitor. Lendo um texto descritivo ele cria as imagens em sua mente ao mesmo tempo que o lê, estimulando desta forma, sua imaginação.

Quando o leitor lê jornais ou livros, quase sempre, conhece alguma palavra nova ou familiariza-se com as formas de expressão, do autor, adotando-as ao uso próprio, daí outra importância da leitura.

Portanto, a leitura, é importante para a formação cultural e social do ser humano, já que, ela interage de várias formas na vida deste.

37

A leitura deveria estar incorporada às ações diárias de qualquer pessoa. Não deveria estar restrita a pedidos de professores nas escolas, como método de avaliação. Lendo se conquista horizontes. 
A leitura precisa ser apresentada já na infância, aos pequenos, como fonte de diversão. Não faltam opções nas livrarias de material para despertar o interesse de tão jovens leitores. Talvez o que falta seja o hábito de tornar a leitura uma rotina.

As vantagens de quem está habituado à leitura são inúmeras. Lendo se viaja por lugares desconhecidos, vivencia-se outras culturas, além do que, qualquer aprendizado ase torna mais fácil.

Uma vez que a alimentação diária cuida do corpo, nada nos impede de incorporara a leitura às nossas vidas para cuidarmos melhor de nossa mente e alma.

48

Quando lemos entramos em contato com o imaginário.

Podemos ser o mocinho, o bandido, o vilão, podemos ser quem quisermos.

Uma boa leitura, faz com que esqueçamos do mundo, e as horas que passamos lendo tornam-se segundos.

Ler é poder, e sentir que somos livres somente com a força do pensamento. Quinze minutos diários de leitura com certeza trará benefícios para a mente e um bom funcionamento da memória

49

Quando começamos a aprender o alfabeto, a primeira vogal, a consoante e daí por diante, tudo muda. Formamos palavras e aprendemos a ler. Lemos tudo; pacote de bolacha, caixa de leite, o saco de pão só para impressionar nossos pais.

Então começamos a ler livros para trabalho de escola, não lemos com muita atenção e acabamos não percebendo a riqueza de detalhes.

Mas quando lemos um romance, mistério ou todos juntos, nos envolvemos na história, sentimos cada gesto, suspiro, choros, riso que o autor escreveu.

Com o passar do tempo percebemos como é importante ler, uma matéria na revista, uma coluna no jornal, assim estaremos atualizados e 
informados, aumentando nosso conhecimento. É sempre uma descoberta, ler é a melhor coisa.

\section{8}

Num mundo cada vez mais padronizado, onde as regras são ditadas pela televisão, um ótima maneira de sair da mesmice e aprender outras coisas, é a leitura.

A leitura estimula o cérebro, a imaginação. Força-o a criar. Com isso o leitor se torna mais criativo e ágil, o que, muitas vezes, ajudará a encontrar respostas rápidas.

Por meio da leitura, pode-se também conhecer diversos tipos de linguagem, lugares e absorver informações diferenciadas.

De acordo com o nível de conhecimento e com o lugar onde se vive, se cria um diferente sentido ao texto, ou seja, cada um tem a sua interpretação sobre aquilo que está lendo.

Ler é conhecer diversas culturas, aprimorar os conhecimentos e estar atualizado com o mundo.

66

O hábito da leitura deve ser desenvolvido desde cedo. Uma criança que lê, será um adulto que lê, desenvolvendo com mais facilidade a escrita, a imaginação e a criatividade. 
Durante a prática da leitura, se absorve automaticamente uma infinidade de palavras, sua grafia e seu significado, colaborando para uma boa escrita e aumento do repertório.

Ao se ler um livro, um jornal ou mesmo uma revista, aprende-se muito. Para estar informado ou mesmo formar uma opinião sobre os acontecimentos é fundamental que a leitura se tome um hábito.

$O$ mundo pode até parecer mais difícil para aqueles que não lêem. Quem lê enxerga as barreiras e fronteiras do mundo com outra visão. Há facilidade para argumentar, falar e escrever bem. Com a leitura , forma-se e se aprende cultura, enriquecendo e engrandecendo o homem.

68

A leitura nos proporciona a oportunidade de conhecimento, a busca de novas palavras e formas de expressão. Ao lermos um livro, um jornal ou mesmo uma revista encontramos um universo de idéias, formas de pensamento que nos influencia em nossa maneira de ser.

$O$ conhecimento que adquirimos com a leitura nos serve para que possamos expressar com melhor clareza. A cada palavra aprendida temos a chance de melhorar nossa escrita, elaborar idéias e expressá-las de uma maneira correta.

A leitura nos apresenta ao mundo da imaginação, onde podemos liberar fantasias, expressar idéias, facilitando a uma melhor compreensão da linguagem escrita e falada. Tudo isso será de grande importância, uma vez que o conhecimento adquirido influenciará na maneira de ser de cada um..

Somos seres pensantes, e a leitura é o combustível para que a máquina humana se desenvolva, e seja capaz de proporcionar um aprendizado eficiente e de qualidade.

\section{1}

A leitura é essencial em nossas vidas, pois através dela, conhecemos melhor o mundo em que vivemos. Podemos aprender as coisas belas da vida e aprender como ser pessoas melhores a cada dia. 
Através dela nossa mente se abre, sentimos o desejo de cada vez mais estar sempre adquirindo sabedoria, que só conseguimos por meio de bons livros. Não consigo imaginar-me sem bons livros, pois se ninguém os escrevessem não teríamos tantas experiências relatadas, que são ricas fontes de conhecimento.

Por isso é bom selecionarmos bons livros para que possam edificar-nos e encher- nos de sabedoria.

\section{3}

A leitura é essencial em nossa vida para que possamos vislumbrar o que somos e onde estamos lemos para compreender ou lemos para começar a apreender. Uma sociedade pode existir sem o hábito de escrever e de fato existe, mas dificilmente irá progredir sem ele.

O ser humano depara-se com a leitura todos os dias e em todos os momentos ao ver notícias, anúncios, bulas de remédio, pequenos versos na passagem do trem, um bom livro.

O livro tem o poder de mudar uma nação. Há fatos e relatos, na história, que comprovam a proibição de determinados tipos de leitura banidos para que as pessoas ficassem na total ignorância e para reprimir qualquer tipo de insatisfação.

O hábito da leitura é fundamental para que não sejamos ignorantes e para que saibamos de nossos direitos e obrigações. Os sonhos também não existiriam porque uma pessoa que não lê, fica sem referência e desconhece o real valor da sua existência.

75

No mundo atual, com as modernas invenções e com a globalização, a comunicação é essencial e por isso o domínio da leitura se tornou tão necessária quanto o ar que respiramos.

Com a rápida evolução que o mundo passa, a leitura nos dá longas pernas para acompanharmos esta corrida. Com ela desfrutamos saborosamente os privilégios que esta evolução nos traz, como a de 
dominar as novas tecnologias, aprender novas línguas, estar inteirado das notícias do nosso país e do nosso mundo.

Além destes maravilhosos regalos que a leitura nos dá, há um especial que é muito poderoso e prazeroso, que é poder nos fazer viajar a vários lugares, conhecer várias culturas sem precisar se locomover, somente com a leitura e com a imaginação.

A leitura é mais importante, é fascinante e essencial. Ler é dádiva, dádiva preciosa de Deus.

80

Muitos de nós desenvolvemos aversão pela leitura, porque muitos professores nos abrigavam a ler textos sem grande interesse para nós, associando a trabalhos e notas. Por isso, não era valorizada nem a leitura, nem autor da obra, todo trabalho escolar era feito através de pressão. Ninguém observava a necessidade da leitura e sim a obrigação.

O que leva alguém a ler não é o reconhecimento da importância da leitura, e sim motivações e interesses que correspondem à sua personalidade e ao seu desenvolvimento intelectual . A leitura é um desdobramento do eu para o outro. Você entra na vida alheia, assume a identidade do personagem, e se vê na história.

Os valores que se podem adquirir através de livros e jornais somente se tornam acessíveis a quem tem o hábito da leitura e possui a capacidade intelectual para ler. Na sociedade de hoje, os livros, a leitura tem um novo significado, tendo em vista o avanço tecnológico que impulsiona a velocidade de tudo que nos cerca, inclusive a informação.

Ler é construir conhecimentos, é trocar, e não só receber, é dialogar, e compreender as intenções do autor, é exercitar o discernimento, refletir sobre opções dos personagens, ler é ampliar a percepção, é ser motivado à observação de aspectos da vida que antes nos passavam despercebidos. Ler bons livros é capacitar-se para ler a vida.

81

Ler, para mim, sempre foi da maior importância. Não faço isso por obrigação, mas porque gosto. 
Na minha opinião, o indivíduo que não lê, fica à margem da sociedade; não tem como se situar, pois pela ignorância está alheio a tudo, até mesmo quanto ao seu papel na sociedade.

Quem não lê, perde a oportunidade de se instruir; deixa de fazer viagens fantásticas, de conhecer universos maravilhosos, de sentir as mais variadas emoções, pois a leitura tem a incrível capacidade de nos transportar no tempo e no espaço sem precisarmos sair do lugar.

Ler é cultura, é deleite, é fascinação.

\section{5}

Já dizia o escritor Monteiro Lobato que: Um país se faz com homem e livros. Isso nos permite refletir a respeito da importância da leitura em nossa vida.

A leitura deveria se tornar um hábito na vida de qualquer ser humano, pois ler é um processo de descoberta que não tem fim, é a porta que se abre para o conhecimento.

A pessoa que tem o costume de ler além de ampliar o seu vocabulário, pois adquire um repertório maior de palavras, dificilmente comete erros de ortografia e pontuação. Além disso, a leitura nos permite utilizar modelos de frases e parágrafos durante a escrita no nosso dia-adia.

No entanto, a importância da leitura vai muito além de fazer com que as pessoas somente escrevam ou leiam bem. A leitura é ainda uma fonte de prazer e satisfação pessoal, pois ela serve de estímulo para que as pessoas gostem de aprender e busquem cada vez mais o conhecimento, seja através de livros, jornais ou pela Internet, tornando-se assim, um indivíduo mais crítico e participativo na sociedade.

\section{6}

Nos últimos anos, o mundo tem presenciado a chamada 'revolução digital', através da rápida popularização da Internet e de outros meios de comunicação. Infelizmente, somente tem acesso a estas tecnologias aqueles que têm um certo poder aquisitivo.

Tem-se discutido muito uma maneira que o governo atual e o anterior encontraram de acabar com a 'exclusão digital', que é através de eventos sociais, como festas e comemorações públicas. Neles, existem 
quiosques ou salas especialmente preparadas com computadores para que pessoas de baixa renda que não têm acesso ao computador e/ou Internet possam aprender mais sobre seus recursos.

Infelizmente, este meio de educação encontrado pelo governo está errado, se olharmos a longo prazo. Aquela pessoa que teve um contato mínimo com o computador durante uma ou duas horas em toda a sua vida em um quiosque desses, com certeza não vai conseguir, alguns dias depois, sequer lembrar como se faz para navegar em um site. $O$ correto seria começar por onde todas as pessoas começam a vida: na escola. Quando uma escola é bem equipada, a criança e o adolescente já saem dela familiarizados com as novas tecnologias, prontas para encarar os desafios de um primeiro emprego.

Quando todas as escolas e bibliotecas públicas, sejam federais, estaduais ou municipais, tiverem condições dignas de educar seus alunos com equipamentos atualizados e eficientes, não precisaremos mais de programas para acabar com a 'exclusão digital' - pois todos já terão o conhecimento.

Temos que nos preocupar com os excluídos de hoje, sim, com os programas atuais do governo. Mas sem esquecer que a criança que não tiver acesso às tecnologias também se tornará um excluído no futuro.

\section{9}

O paulistano é um povo orgulhoso da sua cidade, pois ela é bonita e agradável. Ela nos proporciona todo tipo de serviços, recreação, divertimentos. Os paulistanos recebem todos os tipos de pessoas, vindos de várias partes do Brasil e do mundo, fazendo-a muito acolhedora e simpática. Tudo o que procuramos, aqui encontramos, produtos e serviços exóticos, tradicionais, especiais e raros.

Por todos esses motivos, temos uma população diferenciada e agitada, pois o trabalho que tudo isto dá é imenso. As pessoas correm o dia todo, preocupadas em conseguir sua meta, segurar seu emprego, aperfeiçoar seus estudos, manter suas famílias. Não se dão conta de aproveitar as maravilhas que se pode observar como um parque florido, uma estátua na praça, a arquitetura de um prédio antigo, um teatro, um filme. A correria é tanta que o fazer é maior que o prazer. É uma pena, pois a vida passa e passa sem percebermos que passou. 
270

A leitura é uma das melhores maneiras de se obter conhecimento. Isso porque a leitura além do conhecimento, dá prazer ao leitor.

Lendo, é possível obter conhecimento sobres os dias atuais ou mesmo da antigüidade, além de proporcionar melhores condições ao leitor de escrever e produzir textos.

Podemos aprender sobre o mundo fora do Brasil "ver" lugares que não podemos visitar, tudo isso imaginando através da leitura.

A leitura também ajuda na escolha profissional, e, dependendo da profissão, é essencial ler.

Apesar disso tudo, o brasileiro, lê muito pouco, pôr falta de incentivo ou costume do país que não tem costume de ler.

Devemos, então, incentivar amigos e parentes a experimentarem a leitura como forma de lazer também, não somente para estudo

\section{8}

Não é raro ao abrirmos um jornal ou revista encontrarmos artigos e reportagem contendo uma linguagem repleta de palavras e expressões complicadas não usuais, que dificultam a compreensão do texto pela maioria da população.

A mídia e seus profissionais têm como obrigação divulgar informações de modo verdadeiro, direto, objetivo e imparcial a fim de que toda a população, e não apenas uma parte dela compreenda o que está sendo escrito ou falado.

Ao utilizar-se de um vocabulário difícil e pouco conhecido, os veículos de comunicação a estão, ao mesmo tempo não cumprindo com sua função principal: a de informar claramente a população, como também, estão elitizando a informação, deixando grande parte da população desenformada diante de determinado acontecimento.

Assim se vivemos num país democrático, pelo menos é o que dizem, a informação também deve ser um direito comum de todos e por isso a necessidade de se escrever de forma clara e objetiva, evitando-se o uso de uma linguagem desconhecida e complicada. 
289

No Brasil o índice de analfabetos é muito grande, isso demonstra que a população brasileira é muito fácil de ser manipulada, A maneira mais simples de manipular o "povão" é utilizar palavras complicadas e termos técnicos em meios de comunicação e informação, como jornal e televisão, principalmente.

A população de Ter acesso a informações sem cumplicidade. Se algum programa de televisão tiver como objetivo informar, palavras complicadas, devem ser evitadas. A maioria das vezes estes termos técnicos são utilizados por políticos, que usam estas palavras para manipular a população da classe baixa escondendo os problemas do país, ou estado, que não possuem numa solução imediata como, por exemplo, um problema econômico que, ao ser anunciado é "cheio" de complexidades e a maior parte da população não compreende o que está acontecendo.

A televisão deve informar, logo necessita de um vocabulário simples, pois o ouvinte, geralmente, vem de uma vida sem escolaridade e não possui um vocabulário rico em palavras.

293

As pessoas freqüentam as escolas para aprender sobre a matéria e aprender a ser cidadão.

Um bom jornalista tem um ótimo estudo, principalmente na área de português, mas ele deve saber fazer uso da linguagem de acordo com o leitor, evitando termos técnicos.

Cada linguagem tem sua hora e lugar. Usamos uma forma diferente com os amigos e outra com os pais e professores.

Na televisão, por exemplo, é necessário usar uma linguagem que todos entendam, pois ela é um veículo de comunicação.

Há lugares em que se pode usar a linguagem técnica, por exemplo, em uma reunião de empresa, numa audiência, pois em cada lugar se tem uma linguagem própria para ser usada. Nos meios de comunicação, ela deve ser compreendida por todos e não por determinados grupos. 
A população se torna cada vez mais alienada, ou seja, não tem muito conhecimento sobre o que está acontecendo.

Muitos livros são publicados para um certo tipo de público, os que têm instrução. Os jornais também são publicados para um certo público, os escolarizados. As pessoas analfabetas, porém, não sabem o que acontece, pois não têm acesso a essa linguagem dos meios de comunicação e se tornam cada vez mais alienados, ou seja, estão se "distanciando" do mundo.

As palavras têm uma grande importância, pois podem manipular, nos fazer acreditar em algo que não necessariamente seja verdade... Portanto, tanto as pessoas escolarizadas e analfabetas sofrem a alienação

302

Hoje em dia é difícil se apresentar um programa com a linguagem culta e adequada. Já que a maioria do público são pessoas de classe média baixa e não entendem uma linguagem de "boa qualidade".

Mas nos dias de hoje os programas de TV devem ser falados de uma forma que o público entenda e goste do programa.

No caso do programa do Faustão, ele usa uma linguagem "pobre e ignorante" mas não porque gosto de falar assim e sim porque é preciso falar com uma linguagem "pobre e ignorante" para o "povão" entender e gostar do programa. O programa dele á apresentado a milhões de pessoas e ele tem de conduzir de uma forma adequada para o povo entender e apreciar seu trabalho. 


\title{
REDAÇÕES DE CONCEITO I
}

\author{
(PIORES)
}

54

Muitos imaginavam que com o senso de leitura as pessoas poderiam entrar em um ciclo mais amplo da nossa cultura, porém vemos que esse caminho ainda não se tornou eficaz pela constante falta de leitura das pessoas, podemos notar com freqüência esse mau hábito nos tempos atuais.

Afinal quem não lê sem dúvida é um ser com pouco senso de opinião e vago em seus pontos de vista e totalmente vulnerável em seus critérios.

Analisando essas condições ainda vemos o grande problema de uma pessoa totalmente alienada pelo seu próprio conto.

No entanto vimos a importância da leitura e suas descobertas.

97

Eu acho que essa coisa de rede de internet vai ser um bom negócio se expandir para as escolas públicas, já que as particulares já possuem essa infraestrutura já bem avançada.

Com essa tecnologia as pessoas vão poder ser mais capazes de ter um emprego bom pela frente, porque de agora em diante quem não tiver uma escolaridade boa e um Inglês e uma informática é um analfabeto completo. Por mais que a pessoa seja pobre ela tem o direito e o dever de ter um computadorzinho em casa, nem que seja um 486 conectado à internet.

Bom, esse é o meu modo de ver as coisas, embora tem pessoas que são contra a informatização das escolas, falam que poderia atrofiar o conhecimento das crianças.

99

O governo pretende colocar computadores fora das escolas, para fazer o e-analfabetismo, que fará com que as pessoas aprendam a ler e escrever pela Internet. Mas antes devem colocar computadores nas 
escolas públicas e privadas, para que os alunos aprendam a usar o computador.

O chamado e-analfabetismo não é uma boa coisa que o governo criará, pois a pessoa que é analfabeta não conseguirá usar essa máquina, pois para usá-lo devem saber ler. Essa história de colocar computadores fora das escolas é mais um complemento para que os alunos, depois de aprender a ler e escrever, possam consultar sobre vários assuntos na Internet, como: notícias importantes, fazer trabalhos, consultar sobre algum assunto dado em sala de aula. Dentre outros. Como tudo hoje em dia está nas mãos do computador, o governo também quer fazer dele uma escola. Esse equipamento deve ser usado em escolas para que depois de alfabetizados possam aprender a usá-lo e fora das escolas para que depois que aprendam a usá-lo, possam desfrutar de diversas vantagens que a Internet nos traz. Mas jamais dizer que ele alfabetizará as pessoas, é um absurdo!

\section{2}

A falta de computadores nas escolas públicas e privadas está causando uma enorme deficiência no uso da web. Tais informações que deveriam estar presentes nem salas de aula, na verdade são de privilégio de poucos, que têm em casa um computador ligado à rede mundial.

Esta falta de computadores a nível escolar se dá principalmente pela falta de verba que deveria ser destinada a esse programa de informatização pública e que até mesmo as escolas privadas passam pelo mesmo problema.

O governo planeja democratizar a web, mas ainda não encontrou o melhor caminho, que antes de qualquer coisa deveria proporcionar melhores condições para aquisição de equipamentos de informática.

Deveria ser feito um melhor planejamento neste sentido levando em conta alguns fatores:

- Precariedade nas instalações nas escolas públicas.

-Custo alto de equipamentos para escolas privadas.

Fica claro que é muito cedo para democratizar a web em quiosques de esquinas,

sem antes se atentar aos problemas que as próprias escolas enfrentam. 
106

A idéia de que toda uma nação venha a ter acesso a "Internet" é fabulosa, pois nela encontramos um universo inimaginável de informações e facilidades, que muito podem contribuir na formação e em suas atividades do dia-a-dia de todos os cidadãos.

Porém a democratização da "Internet" sem a conscientização e aculturamento, poderá fazer com que um projeto tão audacioso, não saia do papel, e se sair, poderá amargar um prejuízo muito grande. Por isso, a popularização deve se iniciar dentro de nossas escolas, onde com a devida orientação, formará pessoas conscientes e capazes de utilizar a "Internet" como verdadeiramente um instrumento de trabalho e entretenimento saudável.

A necessidade de termos uma base de pessoas com uma formação adequada, passa a ser tão evidente, que basta observar que dos milhões que hoje acessam a "Internet", poucos fazem dela um uso adequado e se essa popularização ocorrer da forma que está sendo divulgado, esse canal de oportunidades poderá se tornar, nada mais que um malefício para todos

Portanto, frente a uma idéia tão agressiva, porém coerente, se forem tomadas às ações necessárias para garantir uma evolução constante e consciente a "Internet para todos" poderá mudar a história da nossa nação, transformando esse momento em um grande marco.

\section{7}

No meu ponto de vista o governo deveria antes de começar a fazer essa democratização da web, ele deve fazer a alfabetizar, educar, instruir e dar mais educação a população, educação que devemos te uns com os outros e não se prevalecer a lei do mais ixperrto.

A exclusão digital é outro ponto muito importante pois o que vai adiantar democratizarmos a web e ninguém poder utilizá-la, mesmo que seja feito um quiosque em cada esquina, não ira resolver e mais uma vez o governo irá perder tempo e dinheiro com mais uma tentativa de educar a população.

109

Todos nós sabemos que educação se dá em casa, mas dela nada seria sem a escola. Aquilo que aprendemos em casa, colocamos em pratica [prática] em outros lugares, como na escola e o mesmo acontece com a 
escala, que procura educar o profissional e também formar uma pessoa com caráter, para que futuramente possa enfrentar obstáculos profissionais e emocionais.

Não vale nada informatizar um país inteiro sem ter profissionais para trabalhar com aquilo, sem falar em aprendizados paralelos com a informática, como inglês e espanhol. Podemos ver pelo mesmo lado, a dificuldade que o governo vai ter em informatizar casa quiosque em cada esquina. As principais dificuldades serão: renda, material, infra-estrutura e profissionais.

Nos dias de hoje, a procura por profissionais especializados, tem sido cada vez mais constante. Com a utilização cada vez maior da tecnologia, a necessidade de uma resolução rápida de problemas e o surgimento de novas idéias tem sido o motivo principal e a prioridade da maioria das empresas. Na área de informática esse fator é maior do que em outras áreas, já que se trabalha com um conteúdo muito dinâmico.

A importância de uma educação é antes de qualquer evolução na parte da informática é vital, e quem deve fazer essa educação é nada mais, nada menos do que as escolas, sendo elas públicas ou particulares.

129

Eu sou nem a favor e nem contra da nova "linguagem" por um lado além de ser bem melhor e mais rápido se se escrever facilita muito o dia-dia e é sempre muito corrido.

Mais pensando por um outro lado podemos ver que, essa linguagem acaba empobrecendo muito a nossa Língua Portuguesa tão bonita e que deveria ser usada com o seu devido respeito.

Assim posso concluir que o mundo moderno acaba afetando as nossas vidas em muitos aspectos.

\section{4}

Como podemos ver no texto enviado, as pessoas estão cada vez mais economizando a língua portuguesa para encobrir erros da escrita até mesmo pra diminuir a quantidade. Com essa era digital explodindo diariamente, a população está entrando em choque com a gramática, a facilidade de mandar um e-mail é tão grande que alguns conceitos básicos da nossa língua estão sendo esquecidas. 
A mania dos brasileiros de achar um meio mas fácil para resolver os problemas do dia-a-dia, isso se torno tão comum que todos estão acustumados de ver isso diariamente.Na minha opinião(9) com o desenvolvimento dessa nova escrita está cada vez diminuindo a capacidade das pessoas, desenvolver e até aprender a utilizar corretamente o nosso portugues.Com isso não estamos aprendendo mais sim esconder as nossas dúvidas da escrita, este metodo de abreviar tudo o que não sabe escrever, está cada vez mais difícil de controlar.

Com isso tudo que se ve no meio digital as pessoas estão esquecendo de treinar a nossa lingua escrita, mas contudo isso que está tendo nessa revolução da informatica, não tem um meio de controlar mais sim um meio de evitar tantos choques. Isso é que teremos um longo caminho pra tirar os vicios da população, mas nada é perfeito na Terra, devemos ajudar uns aos outros para que podemos vencer essa guerra gramatical.

Mas sempre a linguagem digital estará no nosso meio, mesmo que seja pra uma carta ou pra uma apresentação ela estará entre nós.

\section{8}

Pois como no texto esta explicito de uma certa forma que a tecnologia esta nos trazendo benefícios como o fogo e também o carro entre outros mais com toda tecnologia entre as mais simples e as mais complicadas.

Não se espera que tudo siga conformes os costumes antigos principalmente os brasileiros que pensão que se pude ficar sentado esperado tudo com uma facilidade, simplicidade para tudo já mais levantariam do sofá, então assim tudo que podemos simplificar para melhorar estou de apoio.

É a mesma coisa na velha língua portuguesa para que possam facilitar na escrita ou no dialogo, deve ter sua forma contraída. Agora entra com palavras inglesas no nosso contemporâneo não veja nenhum mal, pois talvez assim estaríamos forçando o brasileiro sai de cima do sofá e ver que a tecnologia digital ou qualquer outra tecnologia que esta excluindo aqueles sem qualificação e o idioma que é uma forte aliada da tecnologia no Brasil. 


\section{8}

Com o grande crescimento da tecnologia digital, adaptações acorreram em nosso meio de vidade forma assustadora, uma delas, a escrita.

A principal idéia nesse mundo tecnológico é passar informações de forma rápida, clara e concisa, o que não agrada os especialistas em cultura e literatura, porém não se trata apenas de erros ortográficos ou até mesmo problemas com acentuação e concordância, e sim a criação de gírias, "verbetes" e siglas, o que empobreçe o português. Alguns estudiosos afirmam que "o português é a lingua mais rica do mundo, porém pouco utilizada", tal afirmação atribui-se ao deslecho da lingua falada, e principalmente a "escrita digital", seja em salas públicas de batepapo os "chats", ou a velha correspondencia hoje modernizada e chamada de "e-mail", mas não é só a internet que revolucionou a escrita, os telefones móvel também estão sofrendo modificações, o que era tão glorificado, falar com pessoas a certas distancias e sem fio,hoje se tornou uma internet movel, com chat, noticias e-mail.

Enfim a Tecnologia esta ai para nos trazer comodidades, e esquecer conceitos, cabe a nos usar e usufruir de forma adequada e benefica.

\section{5}

Antes de democratizar a web em quiosques de esquina, como planeja fazer o governo, deveríamos usar todos os recursos para plugar $100 \%$ das escolas brasileiras, públicas e privadas.

Em todas as esquinas que se passa hoje, sempre tem algum cyber-café, que são apenas lojas que as pessoas vão para se plugar na internet.Mas ainda tem uma parte da sociedade que infelizmente não tem conhecimento e acesso a web.

Mas como a maioria das coisas esse acesso a web deve ser também ensinado nas escolas. Todas as escolas deveriam já ter salas completamente plugadas na web o que não acontece. Para isso se tornar realidade tem que haver uma séria ajuda do governo, que pode estar ajudando para plugar as escolas é incentivando empresas do meio de telecomunicações, a plugar as escolas, e em troca as empresas que plugarem as escolas, poderem fazer propagandas gratuitas, ou estar diminuindo algum impostos que a empresa paga. Com isso as empresas não precisam passar o valor desses impostos para o governo, para que o 
governo repassem para as escolas, as empresas já estariam passando esse valor para as escolas em computadores, peças e manutenção nessas salas plugadas na web. Não pode estar colocando está tecnologia que é a web, cada vez mais em produtos que as pessoas podem ter acesso, se não ter um ensino adequado nas escolas para população do que é a web.

\section{6}

O texto depois de ser analisado trás vários assuntos : como a informática ficou mais freqüente no nosso dia dia, tendo acesso a internet e podendo fazer diversos trabalhos pela rede, o governo quer que $100 \%$ das escolas sejam plugadas a essa tecnologia que é a informática, isso faz com que várias pessoas tenham conhecimento de tudo o que está acontecendo agora nesse minuto.

Como, muitas pessoas não tem acesso a rede, o governo colocou em vários

locais de acesso livre ao público, vários computadores com acesso a rede, nesses locais, tem vários voluntários que ajudam essas pessoas a entrarem num mundo de conhecimento. Muitas pessoas são analfabetas, por isso que o governo está tentando colocar $100 \%$ das escolas plugadas na internet isso ajudaria muito na educação dos alunos alguns exemplos podem ser citados:

Uma é o estudo on-line isso quer dizer que o aluno vai poder estudar a distancia, da sua própria casa, com um professor de plantão tirando todas as dúvidas possíveis.

Como há muita coisa para colocar aqui, vou resumir, concluindo esse texto, há como fazer isso, mas isso custa, muita gente não tem como pagar para ter acesso a rede, isso fica concentrado só em um lugar, as pessoas de classe média, com um salário razoável e a alta sociedade, enquanto isso as pessoa pobres vão ficando cada vez mais analfabetas.

\section{9}

As escolas públicas possuem bibliotecas pobres e de pouco conteúdo, mas ja possuem laboratórios de informáticas, ou seja muitos adolescentes podem se comunicar com pessoas do mundo todo, mas tem dificuldades ao redigir um texto ou uma composição gramátical. 
Mesmo em um paísque não possui tendencia e costumes de ler, e que cada vez mais se comunica com gírias ou sinais, não possui nenhum incentivo a leitura.

O governo pretende democratizar a rede, colocar a informação em todos os caminhos que a mídia propões, mas não tem informações necessárias de um nível intelectual necessário, um conteudo básico admissível.

Uma saída necessária seria uma mudança de costumes dos adolescentes, um maior incentivo do governo e fortalecer as escolas pública e é claro, uma mudança no sistema de ensino.

160

Para que isso acontecesse teríamos que ter uma boa estrura nas escolas para terem um laboratóriio à altura do ensino da escola no ramo da informática, precisaríamos muito do apoio do governo para com a sociedade, principalmente aquela que são mais carentes, a sociedade precisaria se ajudar mais.

As maiorese melhores universidades do mundo estão, lado a lado com escolas, empresas, órgãos de governo e ONGs, redesenhando estratégias e pedagogias para enfrentar o desafio de recriar os espaços que levam da informação ao conhecimento.

\section{3}

O governo deveria não,deve incluir na programação das escolas uma matéria de informatíca no insino fundamental e no ensino médio assim seria um grande passo para combater o analfabetismo da informática seria uma boa pra quem não tem condições de pagar um curso de coputação.

A informação e que falta para muitos jovens que não tem abito de ler jornal e revista é que hoje em dia muitos de nós achamos que já sabemos de tudo ,é quando nós levamos um tombo, aí que a gente vê que não sabemos de nada.

"Que adianta eles nos dar o equipamento, e nos não sabermos manuzeala. 
Hoje em dia quem tem oportunidade de utilizar a Internet tem um ótimo acesso de informações muito ricas, pois por ela podemos acessar a vários lugares da web como bibliotecas, livrarias, sites de procura entre outros que basta apenas indicar a informação desejada ou procurar-la com apenas alguns cliques no mouse que obtemos ótimos resultados de busca.

Mas infelizmente não são todas as pessoas que tem oportunidade de ter um acesso a internet, e ainda muitas delas além disto não vão a bibliotecas ou algo do gênero para que lá possam fazer trabalho, pesquisas ou enfim não tem um acesso fácil a informações ou notícias.

Essas pessoas que não tem possibilidades de ter um computador com acesso a internet ou até mesmo não tem condições de estar custeando revistas ou jornais para ficar informado poderia (poderiam)ter alguma ajuda do governo que pudesse ceder algum lugar de fácil acesso a essa população onde lá existissem acesso a web.

Mas já existe um projeto onde pode se comunicar e ter acesso as informações.

Webescola é aonde estas pessoas podem estar se dirigindo para poder ter este aprendizado á distânica, é uma ótima oportunidade para aqueles que ainda não conseguiram ter o conforto de usar a Web em sua própria casa.

\section{6}

Acredito que será uma revolução esses quiosques de esquina, onde todos terão acesso a rede, e de tabela ao mundo.

Tudo o que será feito vai ser por internet, muito bom estarmos utilizando Dessa tecnologia.

Mas devemos parar e pensar:

Quem são as pessoas que vão utilizar deste recurso?

Qual o tipo de instrução que estes terão?

São perguntas que vão ficar batendo de frente com o projeto.

Acho que deveriam ser implantadas boas conexões, e trabalhado a parte de informática em todas as escolas, tanto públicas quanto privadas, aí seriam dadas as coordenadas e todos seriam treinados.

Ai com uma boa educação e conhecimento a todos, poderiam ser implantados esses quiosques onde todos poderiam desfrutar dessa tecnologia. 
É um bom assunto a ser trabalhado, mas tem que ser bem pensado antes de complementado.

\section{7}

Nas escolas públicas de hoje, o ensino em relação a informática está muito ruim.Se o governo tem como idéia a web em quiosques deveria pensar em dar acesso a informática nas escolas pois no mundo de hoje a internet é fundamental pois é um dos principais meios de comunicação.

As escolas públicas estão ficando para trás pois não tem acesso a internet, por isso o governo antes de levar internet ao público em geral deveria ter prioridade em dar acesso grátis as pessoas mais pobres que estudam em escolas públicas e não tem computador em suas casas.

184

Nestas poucas linhas vamos relatar algumas dificuldade que enfrentamos no nosso dia-a-dia.

Normalmente o indivíduo consegue repousar seis horas, outros cinco, quando o indivíduo dorme pouco ele fica com o sistema nervoso abalado.

Quando o indivíduo vais para o trabalho, ele toma uma condução, ônibus ou metrô, lotado, com muitas pessoas reclamando da vida ("trabalha muito, ganho pouco e outros do governo, prefeito, presidente") etc....

$O$ indivíduo, devido o trânsito lento encontra dificuldade para chegar com pontualidade na empresa, pois alguns tomam três conduções para chegar. Ao trabalho.

$O$ indivíduo tem uma vida atribulada, afadigada por quanto ele tem que estudar após o serviço ele vai para escola. Não se alimenta direito por quanto o seu tempo é escasso. Sem alimentação muitas vezes dificulta o aprendizado.

Mas devemos estudar, nos dias de hoje é primordial estudar, para termos uma boa colocação profissional e trabalhar para alcançar os nossos objetivos. 
202

Numa cidade grande, como a nossa, sempre competitiva e estressada, tudo é muito corrido. Precisamos trabalhar, estudar, levar filhos para a escola, o que faz corrermos o tempo todo, alheios a nossa volta .

Estamos sempre voltados para nossos problemas e as confusões rotineiras, que não captamos a poesia que há em torno de nós.

Ao levantar cedo abrimos nossas janelas e não percebemos o tempo, o nascer do Sol, a beleza que é a chuva, como é aconchegante o frio.

Não reparamos como é bonito o orvalho nas plantas, estamos tão envolvidos com competição e reclamações que não percebemos como a vida é bela.

\section{3}

A moradia em grandes centros urbanos influi diretamente na vida do habitante, uma vez que ela está em detrimento pelo centro urbano.

Uma das desvantagens de morar em grandes centros é conviver com o fator de violência urbana, com subsídios nesse problema as pessoas ficam mais cautelosas e rígidas ao convívio social, que faz com que elas muitas vezes evitem um simples gesto de ajuda ao próximo.

Outra desvantagem de morar em grandes centros é a poluição. Morar na cidade em princípio é viver com a poluição que é lançada no ar pelos carros e fábricas, condenando os habitantes a Ter problemas respiratórios e evidentemente uma morte precoce o que torna essa desvantagem um grande câncer social.

A sugestão dada para quem quer sair da rotina consumista que os grandes centros nos proporciona é viajar e entrar em contato com a natureza.

\section{7}

A população vive uma crise grande nos dias atuais, devido ao crescimento desordenado de nossos centros urbanos. Com isso, a falta de moradia se torna uma das dificuldades que encontramos pela frente, o desemprego também é uma das causas.

Os centros urbanos a cada dia que passa se tornam mais dificultosos, devido ao problema que a nossa população enfrenta. 
Se emplantarem projetos para melhorar as condições esses centros urbanos, não teríamos tantas dificuldades para sobreviver a essa situação.

\section{8}

É comum encontrarmos nos grandes centros dois pontos distintos, um é a "facilidade" ao trabalho e informações, o outro são as desvantagens de viver entre carros e muitas coisas que acabam nos limitando de coisas simples. Um fator determinante na limitação e a violência e o preço, pois vivendo em um lugar onde tudo tem hora marcada fica impossível observarmos algumas coisas que são importantes para uma vida saudável

Á vida social nas grandes cidades fica comprometida, pois com medo as pessoas se defendem ficando em casa, evitam ir ao cinema, teatro, etc.

266

A linguagem culta é importante porque ela faz com que as pessoas ganhem créditos quando for arrumar empregos e também que não tem linguagem culta significa que não pode freqüentar uma boa, e que não vai ter muitas oportunidades durante a vida. Que adianta um país ter a maioria da população sem ter condições financeiras de pagar uma boa escola.

271

A leitura hoje não se destaca como antigamente, adolescentes não dão mais importância para livros didáticos.

Hoje , games, computador,internet, shopping, tomam contas dos adolescentes.

Na maioria das pessoas lêem mais são os adultos que gostam de passar as tardes lendo.

Lógico que é preferível uma leitura que formará um vocabulário melhor, melhor facilidade para ler, etc... 
atenção.

Hoje, lemos só o que nos interessa ou o que chama a nossa

Não há mais aquela incentivação para leitura, como era antes.

Muitas vezes percebemos que são aquelas pessoas cultas, inteligentes, através de seu rico vocabulário, as palavras que usa para conversar. Aí nós pensamos "como é bom ser como ele

272

Hoje em dia, a leitura é uma coisa fundamental, para as crianças, os jovens e para os adultos, pois com uma leitura uma pessoas adquire conhecimento, sua vida social passa a ser mais expressa, a pessoa lendo sabe conversar melhor, sabe escrever melhor. A leitura é importante porque lendo você o que está acontecendo no mundo isso é, quando você ler jornal ou uma revista, e uma pessoa quer ler um livro muitas vezes ela tem imaginações, criatividade, e em muitos livros o autor conta de sua vida, fazendo com isso que as pessoas leiam e reflitam. A leitura também é importante para uma criança que está começando a aprender a ler, pois é a base de seu futuro

A leitura é importante para os jovens, pois pode ajudá-los em sua vida profissional mais para a frente.

273

A leitura é fundamental para todos nós. Ela nos ensina tudo: cultura, política, economia, política... Tudo que é possível e existente, ela nos mostra.

Mostra pessoas que revolucionaram a história e que fizeram a história. Muita gente penou para tornar o mundo melhor. É nossa obrigação como cidadão é saber e ler sobre e estes.

Para tudo isso é importante ler, e aprender sobre tudo, mas hoje em, dia a situação está precária não há aproveitamento nenhum dos livros que temos e a escola pública (que são a grande maioria) não dão a assistência devida para os jovens e não ensinam que é importante ler. 
A leitura é de extrema importância para o ser humano.

A leitura é essencial para o ser humano, pois com ela se adquire conhecimento, cultura entre muitas outras qualidades.

Para uma pessoas Ter uma boa formação é necessário que ela tenha o hábito da leitura e também para passar no vestibular ela é obrigada a ler uma porção de livros.

Resumindo é muito importante cultivar o hábito da leitura pois com ela sempre estaremos aprendendo e adquirindo qualidades

\section{5}

Hoje a leitura é uma das coisas que são necessárias para se fazer a cultura de um homem.

Ela é importante para o trabalho, é importante para desenvolver a nossa interpretação de texto. etc

Hoje, a pessoa que está a par dos assuntos do mundo, sabe o que acontece em seu país, se a situação para seu trabalho está boa (se a moeda influi)

Se a pessoas lê bem regularmente, ela consegue conversar, se expressar melhor, fala o português direito e erra ao falar poucas vezes.

A leitura é valorizada no meio do trabalho é importante, pois a pessoa que está a par nos assuntos desenvolve capacidade de raciocínio melhor, ou seja, ele desenvolve mais.

276

Todos tentam se motivar para a leitura. Comece a ler você conseguirá ampliar suas idéias.

Quando se lê você abre a cabeça. Aprimoramos a imaginação . No começo você não gosta de ler, mas isso é uma questão de tempo você se acostuma-se a ler e começamos a sentir prazer misto.

Além de tudo isso, também se adquire imensa cultura. Você aprende muito. A capacidade de aprender aumenta .A gramática e ortografia melhoram. Adquire-se um conhecimento geral.

Depois de todos esses conselhos, imagino que você irá começar a ler. Comece com livros fáceis e depois vá lendo os mais difíceis. 
280

Ler é algo extremamente boa, pois lendo se adquire conhecimentos, ou seja, conhece novas culturas, enriquece seu vocabulário, etc. Mas o mais interessante é ler sem repressão sem prazos ou pressa para acabar, sempre lendo o quanto quiser, quando quiser, mas o importante é ler. Falar que é chato, é uma mentira, pois, existe vários livros, jornais, etc... que falam sobre diversos assuntos, assim, agradando a todos. Não é necessário, ler um livro de quinhentas páginas, leia um livro pequeno para ir se acostumando, e depois vais aumentando a "dose" pois independente das páginas, o legal é se entreter no livro, ou seja não querer parar de ler. Mas o importante é sempre estar lendo, mas que seja um gibi, ou uma reportagem, o importante é sempre estar adquirindo cultura.

282

Ler é algo extremamente importante para nossa vida, pois, lendo aprendemos melhor nosso vocabulário e ampliamos nossa visão de que lendo podemos imaginar e viajar nas histórias escritas.

Quem não lê, nunca vai saber este saboroso sabor da leituras e além de conhecer outras culturas e novas histórias, a leitura é um mundo cheio de lugares, aventuras românticas, dramas e até lições que nas quais podemos colocar em prática, ler é aprender a viver

Por estes o melhores dos motivos devemos exercitar o hábito da leitura, assim podendo um dia escrever, sabendo fazer uma boa leitura, podemos aprender a atenção do leitor e até dissertar sobre as curiosidades.

\section{3}

As drogas, infelizmente ainda são um problema muito antigo, porém, preocupação mais atual por parte dos pais, professores e governantes não poderia existir.

Nesta sociedade tão fria, desumana, apegada somente às questões de consumo quando os valores e sentimentos de nada valem... Um grupo está perdido nesta confusão: são os jovens. Eles geralmente passam por uma fase que exige atenção pois estão se tornando adultos, deixando de ter a proteção infantil encaram o mundo sozinhos, com todos os conflitos que este possa lhes possibilitar. 
No meio dessa turbulência, o desejo de ter, consumir, poder, se mistura, e o não ter, não poder, se resulta em revoltas e o caminho mais comum, a solução mais rápida tem sido as drogas.

Essa afirmação perece a habitual, é mesmo! Porque o problema é habitual e a problemática se estende para os pais perdidos, às vezes, despercebidos, para o professores, que convivem com os jovens e conhecem a sua realidade, sem mencionar os governantes, que parecem fingir que está tudo bem. Todos acreditam que drogas são normais para os jovens é uma fase, porém até quando?

\section{4}

O jovem dos dias de hoje, já não quer mais saber de ir a cinemas, passear com os pais ou participar de almoços na casa dos avós. Hoje querem ir muito além, buscam o prazer, mesmo que isso custe muito alto.

Sem medir esforço os jovens saem nas noites, fazem sexo, arrumam confusões, perigosíssímas, andam em velocidades com seus carros e na maioria das vezes usam drogas.

$O$ resultado de um grande número de jovens que estão nesta situação é triste, pois acabam machucados, doentes e/ou mortos isso em virtude da globalização que mostra crescente e dominante, que apresenta o poder, que vangloria o inalcançável e extinga os desejos que até o momento pareciam utópicos.

O combate a estes comportamentos é algo muito delicado e deve partir da família que provida de estruturas sócio-econômicas e uma dose grandiosa de valores poderá resgatar a auto-estima e o prazer significativo de viver que enunciamos como necessários

\section{6}

O número de adeptos do uso de drogas é crescente, principalmente, entre os jovens. A influência do grupo que vivem é determinante para seguirem esse triste caminho. $O$ outro fator importante está na estrutura familiar, que dá suporte para o jovem optar ou não pelo uso das drogas.

Na adolescência é tendência geral acharem que nada vai atingilos. É quando aflora a autoconfiança e o desejo de fazer novas descobertas. Devido a essas características os jovens são tão vulnerável às drogas. 
A solidez familiar é fundamental para manter os jovens longe das drogas, já que o monólogo e o equilíbrio são permanentes nessas famílias. Portanto, nada melhor que sabermos onde nossos filhos andam e com quem estão.

\section{8}

A principal causa que leva um jovem a usar drogas é o medo de não fazer parte do grupo em destaque entre as demais pessoas.

$O$ jovem que está sempre no auge da fama e para isso ele tem que praticar e usar tudo o que é moda dentro de seu convívio pessoal

Geralmente os mais bem vistos como atraentes, ousados e diferentes, conhcem ou usam drogas e desta forma passa a meio impor um padrão geral para os que quiserem fazer parte de seu grupo a partir daí começa um círculo vicioso, que leva a morte.

Esse tipo tem como causa a dependência orgânica e a exclusão do grupo social

319

Poderia dar mais de um motivo para o uso de drogas na adolescência, mas descreverei a influência do meio em que o jovem vive.

$O$ jovem, atualmente, tem acesso a todo tipo de influência, seja ela negativa ou positiva, mas a necessidade da socialização pode ser a grande causa da utilização das drogas.

Por ser fácil o acesso aos traficantes, o jovem conhece as drogas muito cedo e caso o seu grupo de amigos tenha interesse no uso, tudo fica mais fácil, ou pelo menos favorável ao uso.

Conhecer os damos causados pelas drogas é um fator positivo para o jovem, pois terá a iniciativa em dizer não ao viciado amigo ou retirar-se do grupo de má influência.

Acredito que a conscientização é que salvará nossos jovens

320

Um dos maiores problemas vividos por jovens de todas as classes sociais, é o consumo de drogas que está espalhado por todo o mundo e que 
torna-se algo cada vez mais descutido e a cada dia menos perspectiva de controle e solução.

Há vários pontos de drogas espalhados por todo lugar, pois é algo que se consegue com muita facilidade

330

Como o próprio nome diz: droga é uma droga. Um mal que vem se alastrando entre os jovens de uma forma incontrolável. Nem mesmo os pais conseguem controlar seus filhos, pois a droga está muito presente em nossa mídia, principalmente ns rede da internet, com propagandas e vendas de pílulas (exctase) com facilidades para adquiri-las.

Infelizmente $90 \%$ dos jovens que consomem drogas, conseguem se livrar delas posteriormente, pois sua dependência é muito forte, e sua falta causa fortes reações no organismo, levando assim o jovem a procurar cada vez mais pelo seu uso e a procurar drogas mais fortes para saciar-se.

Como vemos fica difícil manter um controle para manter os jovens longe das drogas, talvez a solução esteja ainda presente dentro de casa, com uma boa criação e muito diálogo dos pais, expondo aos seus filhos o grande perigo de se envolver nas drogas.

338

Os jovens, na maioria das vezes, tendem a tomar como legal o correto a ser feito, justamente aquilo que a sociedade como um todo Ter por conceito dito como errado pelo simples prazer do exercício da rebeldia.

Somando a isso a falta de harmonia entre as pessoas, a falta de comprometimento e união familiar e ainda possíveis crises financeiras e pessoais que o indivíduo sofra, a droga tem sido a fuga mais freqüente.

Uma vida que seja cultivada sem amor e atenção sem troca de experiências, valores e principalmente educação, não pode gerar bons frutos a si próprio e muito menos desenvolver algo construtivo ao coletivo.

É preciso antes de uma preocupação mundial relacionada às drogas, com a mobilização de todos, que haja a diminuição dessas áreas de aplicação das possíveis soluções. É preciso começar da raiz do problema, é necessário que exista amor, família, força de vontade, para gerar 
educação, e quem sabe a partir deste ponto dar um passo rumo a cura da sociedade.

\section{9}

Hoje em dia, num mundo em que as possibilidades para se conseguir de tudo aumentaram, vemos que o rumo do mundo se perdeu. Vemos jovens se drogando em plena luz do dia, filhos matando seus pais por dinheiro e a exploração de menores nos mais diversos setores. Isso nos leva a questionar: porque isso ocorre? Será culpa dos pais? As pessoas ainda se deixam influenciar por outras? É muito mais complicado.

A psicologia explica que o indivíduo já nasce predisposto a ser mau e que apenas aflora sua brutalidade após um pequeno despertar em qualquer tipo, isso pode ser verdade, mas as injustiças sofridas hoje dado o abuso de poder de alguns, leva algumas pessoas a descarregarem sua revolta num ato violento ou o leva a fugir para um campo de fantasia. Mas esse ato impensado leva à resultados drásticos: se a pessoa não morrer ela pode tentar se recuperar mas nunca será o mesmo, nem será visto como "normal". Embora se questione sobre o preconceito e se relute muito contra ele, todos possuem nem que seja um pouquinho .

Tanto é verdade que o emprego de ex-usuários é geralmente, vendedor ambulante de coletivos ou andarilhos por que não? Eles não possuem um emprego fixo, até mesmo, pelo fato de sua aparência ser desfigurada.

Assim essas pessoas não tem a quem recorrer senão às pequenas ONG'S que mal conseguem o lugar, daí a necessidade dos "pacientes" se tornarem vendedores, se não bastasse o descaso para com eles quando eram jovens, passam por mais descaso agora: velhos desfigurados e principalmente ex-drogados.

\section{0}

Hoje, talvez o maior problema enfrentado pelos adolescente é o da drogas.

Seja por curiosidade, por pressão do grupo, ou problemas pessoais e familiares, a pessoa fica propensa a experimentar e depois, utilizar essas substâncias nocivas ao organismo. 
Drogas considerada por muitos "leve", como a maconha, poderá deixar a pessoas desligada e sem interesse pelos estudos, ou por outras coisas e o jovem com o tempo, acaba adquirindo uma dependência psicológica. Há uma sensação de relaxamento, porém em outras pessoas, poderá funcionar como um depresso.

No caso d cocaína e do crack, além d dependência psicológica, o indivíduo vai desenvolvendo uma dependência física e a interrupção brusca do seu uso, pode causar a "sindrome de abstinência". Essas substâncias são estimulantes, deixando a pessoa agitada e depois do efeito, vem a depressão.

A família é fundamental nesta questão, depois ela conversando, alertará o adolescente e se acaso for encontrada alguma quantidade de algum entorpecente, agir de maneira sensata e explicar os possíveis danos à saúde 
ANEXO 2 


\title{
CONJUNTO DE REDAÇÕES ESCOLHIDAS
}

\author{
ALEATORIAMENTE
}

\section{Redação n 1}

Apesar de que as drogas estão presentes no nosso dia-a-dia muito pouco podemos fazer a respeito. Nem a polícia nem o governo conseguem segurar um pouco pelo menos o consumo destas.

Fala-se que a maioria dos jovens consomem drogas, mas isto não é verdade, tem muitos jovens que graças a sua família conseguem ficar longe das drogas devido que na sua família existem pais protetores, amigos, que explicam que droga, o nome diz, é droga. Inclusive muitos jovens tentam ajudar as pessoas dependentes. Já a polícia e o governo na maioria das vezes não conseguem controlar o consumo nem a venda, não sabemos s é por falta de interesse ou por falta de meios.

Mas nem tudo está perdido, graças a campanhas e organizações não governamentais e a consciência da população a situação que era muito complicada está começando a melhorar.

\section{Redação no 2}

A droga está presente na vida dos jovens não só na escola, mas em todos os lugares. Seus usuários não são apenas das classes baixas, também há o consumo de drogas por pessoas das classes médias.

Os principais fatores para a utilização das drogas são: baixa estima, falta de apoio familiar, más companhias, entre outros.

Para que essa situação seja controlada é necessário haver projetos dos país que ajudem os jovens a se manterem ativos e livres das drogas, como: trabalhos voluntários em escolas públicas e estaduais, que ofereçam trabalhos, façam jogos e brincadeiras, enfim que dê a atenção e carinho que estão precisando para se reerguerem e largarem o mundo das drogas 
Redação no 3

A cada dia percebemos o envolvimento dos jovens com as drogas, cresce assim o número de adolescentes que fazem uso desse produto tóxico.

Os jovens passam muitas vezes a consumir drogas devido à falta de amor, carinho dos pais, o envolvimento com colegas do grupo que fazem uso, isto é, para não sentirem excluídos passam a fazer o consumo da mesma.

Os pais, muitas vezes, só ficam sabendo por intervenção dos professores de amigos, só assim começam a tentar recuperar a juventude dos filhos aproximando-se e mostrando o caminho que eles devem seguir.

O jovem quando procura esse caminho não sabe que está jogando sua vida para o "buraco", por isso nenhum adolescente deveria experimentar as drogas, pois é um caminho sem volta.

\section{Redação no 4}

O consumo de drogas entre os jovens e adolescentes vem preocupando cada vez mais os pais, o governo e a sociedade em geral. Muitas ações poderiam ser feitas por parte deles para tentar livrar estes jovens das drogas.

Atualmente, o acesso às drogas é muito fácil. Encontra-se em cada esquina, em cada bairro, um traficante disposto a fornecer drogas aos jovens usuários. Também nunca faltam a eles fregueses de pouca idade interessados em seus produtos.

Isto ocorre porque não há policiamento suficiente nos bairros e também não se aplicam leis severas a estes crimes nossos, gerando uma situação de impunidade no que se refere aos adolescentes usuários, a causa mais decorrente é a falta de estrutura familiar e de diálogo, deixando o adolescente sem apoio e orientação. A cooperação do governo também é importante, pois não dão perspectiva nem de trabalho nem de lazer e estes jovens, que acabam vendo nas drogas a única solução, arriscando suas vidas seu desenvolvimento e seu futuro. 
Diariamente nos deparamos com casos de adolescentes que estão desperdiçando suas vidas e se entregando ao terrível mundo das drogas.

A adolescência é uma fase de grande transição na vida do ser humano, e é nela que ele tende a se revoltar contra tudo e contra todos. Uma saída encontrada pelos adolescentes para livrarem-se de seus problemas são as drogas, que infelizmente passam a ser suas grandes amigas.

Com isso, o adolescente está entrando em um mundo que talvez não permita que ele volte para trás e perceba que errou.

Hoje em dia, muitos adolescentes largam os estudos e até mesmo a família para viver apenas de drogas, que darão a ele prazer.

A criança desde cedo deve ter uma boa educação baseada no carinho, na atenção e no respeito, para que nunca tenha motivos para utilizar drogas, que infelizmente podem ser compradas em qualquer lugar

\section{Redação n 6}

Pesquisas mostram que é cada vez maior o número de jovens que usam drogas, isso revela a situação em que vive nosso país. Os jovens se drogam por inúmeros motivos, pode ser por influência do grupo, por buscar refúgio para seus problemas ou mesmo por curiosidade.

$O$ primeiro motivo se deve ao fato a fragilidade do jovem em relação aos amigos e para continuar a fazer parte do grupo, começa a seguir os outros, ou até mesmo por curiosidade, já que vê os outros fazendo.

As drogas podem servir de fuga dos problemas vividos em casa ou na escola, os jovens acham que usando drogas se livrarão dos problemas.

Precisamos dar um basta nesta situação, mostrar aos jovens que esse é um caminho perdido e que existem tantos outros que também os farão felizes.

\section{Redação no 7}

Dentre os grupos de jovens, não é raro encontrar algum que não tenha tido experiências diretas ou indiretas com drogas. Quem não 
experimentou ou faz uso, conhece alguém que já os tenha feito. Parece que as drogas estão sendo cada vez mais associadas à juventude.

Na verdade as drogas são um problema que afeta a todos. Mas, o jovem por estar em uma fase de descobertas e mudanças, tende fica mais susceptível a elas.. Principalmente, pela influência do grupo que, no momento, passa a ser sua família e sua família (verdadeira) parece distante de sua realidade. A família nesse momento tem fundamental importância na orientação desse jovem para que ele não entre no vício das drogas. A orientação desde cedo, é essencial ao jovem, para que ele construa valores e diga não ao vício sempre.

\section{Redação nº 8}

As drogas estão aí, disponíveis para quem quiser experimentálas ou usá-las habitualmente. Não há mais intimidação de seu comércio pelas ruas, bares, danceterias e portas de escolas, locais em que se encontram jovens freqüentemente.

Muitos deles por curiosidade, conflitos familiares pessoais ou influência de amigos, experimentam as drogas disponíveis em seu meio, causando, na maioria das vezes, a grande vilã dos adolescentes: a dependência química.

Utilizada como fuga, curiosidade ou influência, o fato é que a droga conduz os jovens a um caminho quase sem volta

\begin{tabular}{ccrr} 
& \multicolumn{4}{l}{ N } \\
Redação & \multicolumn{4}{l}{ Operadores N Palavras } & FreqüênciaRel \\
1 & 16 & 141 & 0,11347518 \\
2 & 16 & 113 & 0,14159292 \\
3 & 11 & 123 & 0,08943089 \\
4 & 16 & 164 & 0,09756098 \\
5 & 20 & 146 & 0,1369863 \\
6 & 16 & 134 & 0,11940299 \\
7 & 12 & 135 & 0,08888889 \\
8 & 7 & 86 & 0,08139535 \\
& Média & & 0,10859169
\end{tabular}


ANEXO 3 


\section{CRITÉRIOS DE AVALIAÇÃO SARESP \\ (SISTEMA DE AVALIAÇÃO DE RENDIMENTO ESCOLAR DO ESTADO DE SÃO PAULO)}

CRITÉRIOS PARA A ATRIBUIÇÃO DE CONCEITOS NA CORREÇÃO DAS REDAÇÕES DO ENSINO MÉDIO - $1^{\text {a }}$ A $3^{\text {a }}$ SÉRIES 


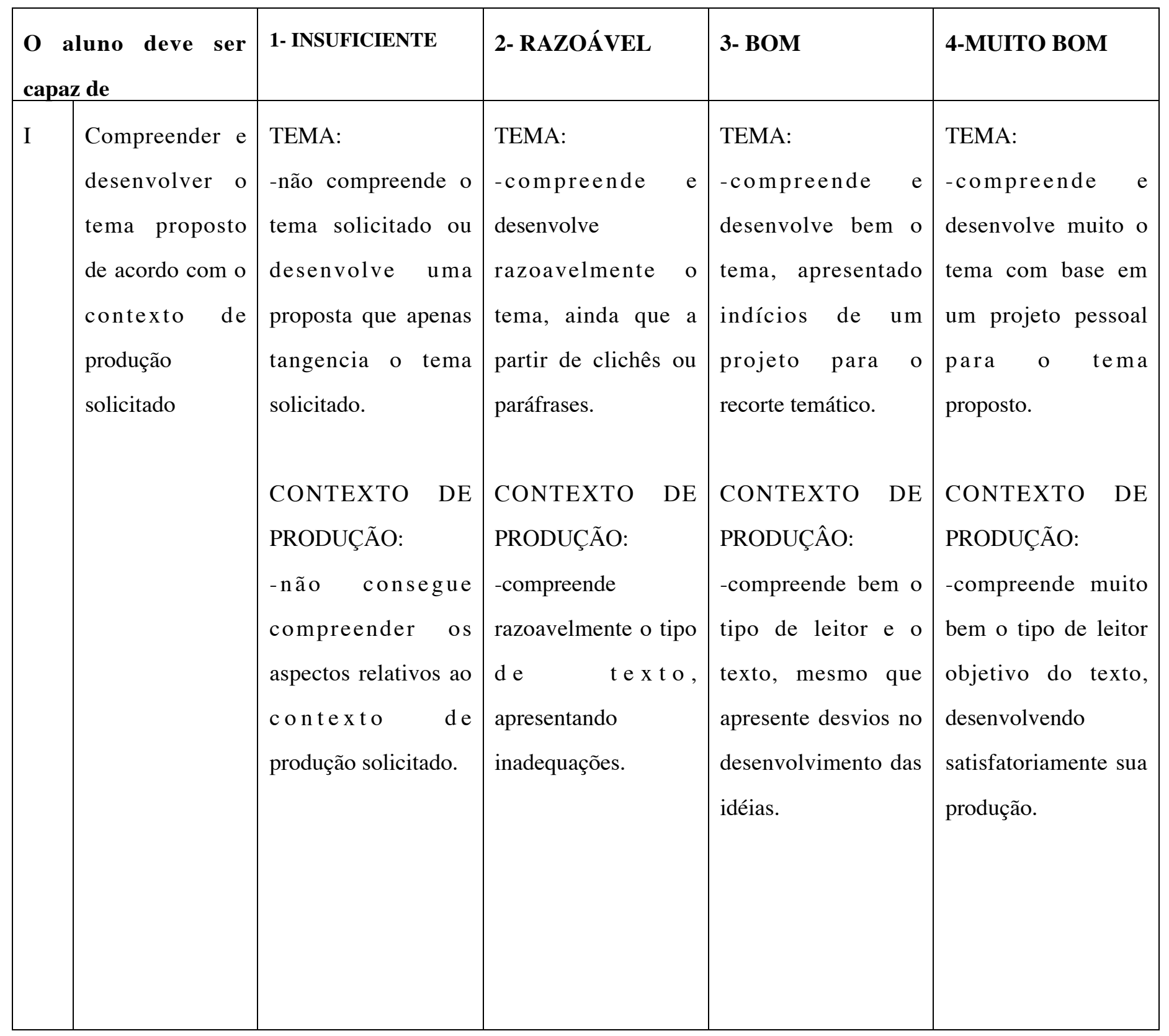




\begin{tabular}{|c|c|c|c|c|c|}
\hline II & $\begin{array}{l}\text { Elaborar um } \\
\text { texto } \\
\text { dissertativo }\end{array}$ & $\begin{array}{l}\text {-não apresenta o tipo } \\
\text { de texto solicitando; } \\
\text { ou a presenta } \\
\text { estrutura } \\
\text { embrionária de texto } \\
\text { dissertativo; ou } \\
\text { apresenta } \\
\text { precariamente } \\
\text { informações, fatos e } \\
\text { opiniões } \\
\text { relacionados ao tema } \\
\text { e, por isso, a } \\
\text { e strutura } \\
\text { apresenta de forma } \\
\text { fragmentada ou } \\
\text { circular. }\end{array}$ & $\begin{array}{l}\text {-elabora } \\
\text { razoavelmente um } \\
\text { texto dissertativo, } \\
\text { mesmo não } \\
\text { conseguindo } \\
\text { explicar a tese; ou } \\
\text { produzindo os } \\
\text { elementos da } \\
\text { proposta, } \\
\text { parafraseando-os. }\end{array}$ & $\begin{array}{l}\text {-elabora bem um } \\
\text { texto dissertativo, } \\
\text { mesmo apresentando } \\
\text { des vios na } \\
\text { organização, } \\
\text { conseguindo } \\
\text { explicitar um projeto } \\
\text { de um texto com } \\
\text { uma tese articulada } \\
\text { aos argumentos, } \\
\text { mes mos } \\
\text { previsíveis, para a } \\
\text { defesa de seu ponto } \\
\text { de vista. }\end{array}$ & $\begin{array}{l}\text {-elabora muito bem } \\
\text { u m te x to } \\
\text { dissertativo, } \\
\text { conseguindo } \\
\text { explicitar um projeto } \\
\text { de texto com uma } \\
\text { tese articulada aos } \\
\text { argumentos, para a } \\
\text { defesa de seu ponto } \\
\text { de vista. }\end{array}$ \\
\hline
\end{tabular}




\begin{tabular}{|c|c|c|c|c|c|}
\hline III & $\begin{array}{l}\text { Organizar } \\
\text { texto de foram } \\
\text { lógic a } \\
\text { produtiva, } \\
\text { demonstrando } \\
\text { conhecimentos } \\
\text { dos mecanismos } \\
\text { lingüísticos o } \\
\text { textuais } \\
\text { necessários para } \\
\text { a construção da } \\
\text { dissertação. }\end{array}$ & $\begin{array}{l}\text {-organiza } \\
\text { precariamente as } \\
\text { partes do texto, } \\
\text { apresentando grande } \\
\text { dificuldade em } \\
\text { registrar os fatos e } \\
\text { dar comunidade ao } \\
\text { sentido do texto; } \\
\text { produz um grande } \\
\text { núm e ro de } \\
\text { justaposição de } \\
\text { palavras e/ou frases } \\
\text { pouco relacionadas. }\end{array}$ & $\begin{array}{l}\text {-organiza } \\
\text { razoavelmente as } \\
\text { partes do texto, } \\
\text { demonstrando } \\
\text { alguma dificuldade } \\
\text { p a r a d a } \\
\text { continuidade de } \\
\text { sentido e/ou para } \\
\text { manter a progressão } \\
\text { temática; apresenta } \\
\text { problemas } \\
\text { freqüentes de } \\
\text { inadequação na } \\
\text { utilização dos } \\
\text { recursos coesivos. }\end{array}$ & $\begin{array}{l}\text {-organiza bem as } \\
\text { partes do texto, } \\
\text { podendo apresentar } \\
\text { problemas pontuais } \\
\text { na utilização dos } \\
\text { recursos coesivos; } \\
\text { enfrentando } \\
\text { estabelece uma } \\
\text { continuidade do } \\
\text { sentindo e/ou uma } \\
\text { progressão temática. }\end{array}$ & $\begin{array}{l}\text {-organiza muito bem } \\
\text { as partes do texto, } \\
\text { utilizando os } \\
\text { recursos coesivos de } \\
\text { forma adequada e } \\
\text { variada mesmo } \\
\text { apresentando, } \\
\text { eventualmente, } \\
\text { problemas no uso } \\
\text { dos elementos } \\
\text { coesivos. }\end{array}$ \\
\hline
\end{tabular}

\begin{tabular}{|l|l|l|l|l|}
\hline O aluno deve ser capaz de & 1- INSUFICIENTE & 2- RAZOÁVEL & 3- BOM & 4- MUITO BOM \\
\hline
\end{tabular}




\begin{tabular}{|c|c|c|c|c|c|}
\hline III & $\begin{array}{l}\text { Organizar o } \\
\text { texto de forma, } \\
\text { lógica e } \\
\text { produtiva, } \\
\text { demonstrando } \\
\text { conhecimentos } \\
\text { dos } \\
\text { mecanismos } \\
\text { lingüísticos e } \\
\text { textuais } \\
\text { necessários } \\
\text { para a } \\
\text { construção da } \\
\text { narrativa. }\end{array}$ & $\begin{array}{l}\text {-organiza } \\
\text { precariamente as } \\
\text { partes do texto, } \\
\text { apresentando grande } \\
\text { dificuldade } \\
\text { em registrar ao fatos } \\
\text { ao sentindo do texto; } \\
\text { produz um grande } \\
\text { n ú m e r o de } \\
\text { justaposição de } \\
\text { palavras e/ou frases } \\
\text { pouco relacionadas. }\end{array}$ & $\begin{array}{l}\text {-organiza } \\
\text { razoavelmente as } \\
\text { partes do texto } \\
\text { demonstrando alguma } \\
\text { dificuldade para dar } \\
\text { continuidade de } \\
\text { sentindo e/ou para } \\
\text { manter a progressão } \\
\text { temática; apresenta } \\
\text { problemas freqüentes } \\
\text { de inadequação na } \\
\text { utilização dos } \\
\text { recursos coesivos. }\end{array}$ & $\begin{array}{l}\text {-organiza bem as } \\
\text { partes do texto, } \\
\text { podendo } \\
\text { apresentar } \\
\text { problemas } \\
\text { pontuais na } \\
\text { utilização dos } \\
\text { recursos coesivos, } \\
\text { entre tanto } \\
\text { estabelece uma } \\
\text { oportunidade de } \\
\text { sentido e/ou uma } \\
\text { progressão } \\
\text { temática. }\end{array}$ & $\begin{array}{l}\text { organiza muito bem as } \\
\text { partes do texto, } \\
\text { utilizando os recursos } \\
\text { coesivos de forma } \\
\text { adequada e variada, } \\
\text { mesmo apresentando, } \\
\text { eventualmente } \\
\text { problemas no uso dos } \\
\text { elementos coesivos. }\end{array}$ \\
\hline IV & $\begin{array}{l}\text { Utilizar os } \\
\text { conhecimentos } \\
\text { lingüísticos da } \\
\text { norma padrão } \\
\text { para o texto } \\
\text { escrito }\end{array}$ & $\begin{array}{l}\text { conhecimento } \\
\text { insuficiente da norma } \\
\text { padrão para o texto } \\
\text { e s c rito, não } \\
\text { conseguindo utilizar } \\
\text { a variante lingüística } \\
\text { do tipo de texto; } \\
\text { produção solicitados; } \\
\text {-apresenta muitas } \\
\text { inadequações } \\
\text { gramaticais e/ou } \\
\text { transgres sões na } \\
\text { escrita (ortografia, } \\
\text { pontuação, } \\
\text { organização não está } \\
\text { justificada pelo } \\
\text { contexto; utiliza } \\
\text { comanamanamea }\end{array}$ & $\begin{array}{l}\text {-demonstra } \\
\text { conhecimento } \\
\text { razoável da norma } \\
\text { padrão para o texto } \\
\text { escrito, utilizando } \\
\text { razoavelmente a } \\
\text { variedade lingüística } \\
\text { do tipo de texto e } \\
\text { contexto de produção } \\
\text { solicitados; } \\
\text { gramatic a is ou }\end{array}$ & $\begin{array}{l}\text {-demonstra bom } \\
\text { conhecimento da } \\
\text { norma padrão para } \\
\text { o texto escrito, } \\
\text { utilizando bem a } \\
\text { variante lingüística } \\
\text { do tipo de texto } \\
\text { solicitado e do } \\
\text { contexto de } \\
\text { produção, mesmo } \\
\text { apresentando } \\
\text { algumas } \\
\text { inadequações } \\
\text { gramaticais ou } \\
\text { transgressões na } \\
\text { escrita. }\end{array}$ & $\begin{array}{l}\text {-demonstra muito bom } \\
\text { conhecimento da norma } \\
\text { padrão, sabendo utilizar } \\
\text { be m a variante } \\
\text { lingüística do tipo de } \\
\text { texto solicitado e } \\
\text { contexto de produção, } \\
\text { com pouca ou nenhuma } \\
\text { inadequação gramática e } \\
\text { ortográfica. }\end{array}$ \\
\hline
\end{tabular}




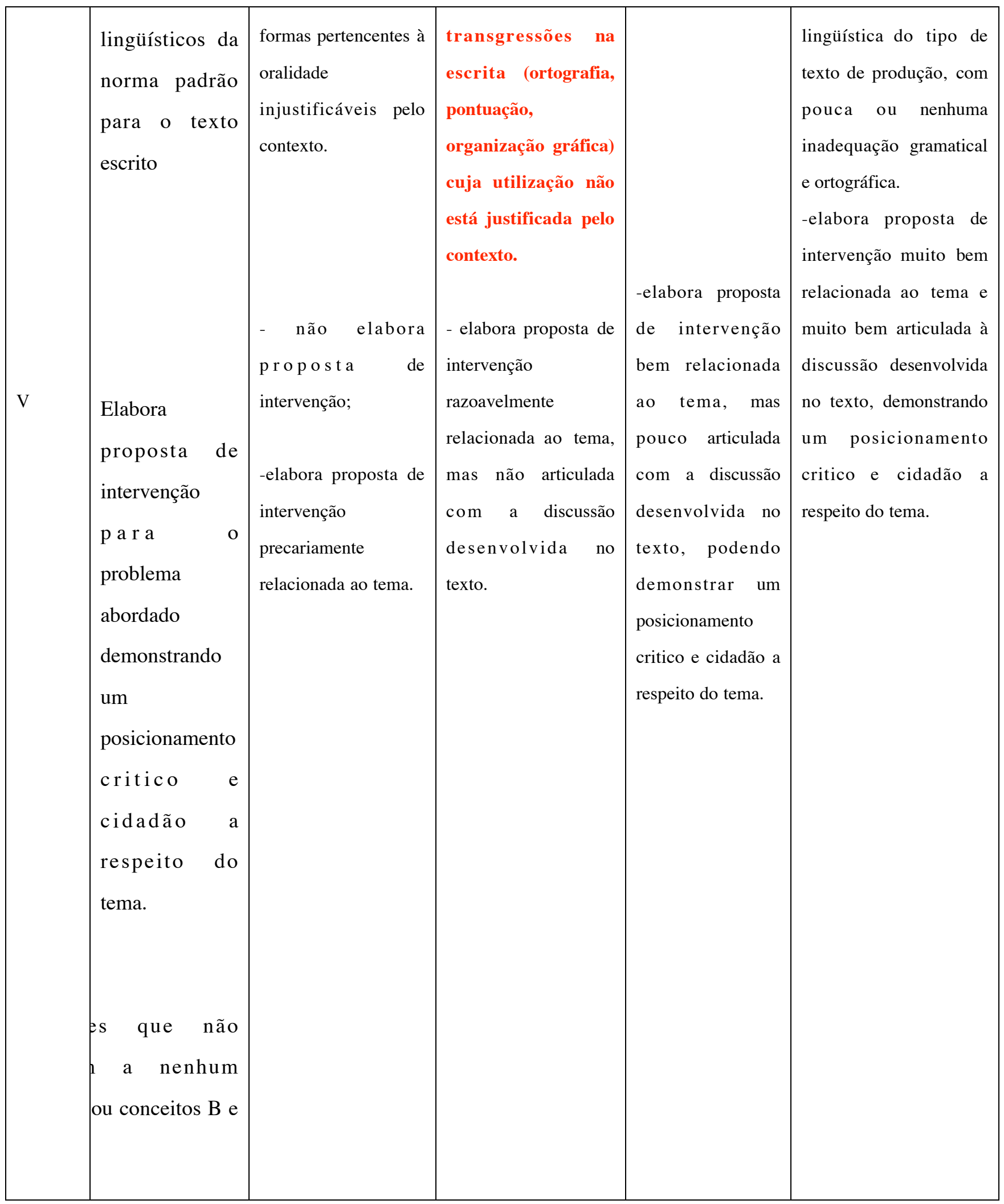

- $\quad$ B - Redação em branco 
- A - Redação anulada- aquela que revela pouco domínio do sistema de escrita: composta por letras isoladas ou frases inacabadas; com uma ou duas linhas e/ou transcrita de textos do Sabesp e simplesmente com desenho/grafismos. 